University of Michigan Law School

University of Michigan Law School Scholarship Repository

Articles

Faculty Scholarship

$1-1976$

\title{
The Jury and the English Law of Homicide, 1200-1600
}

Thomas A. Green

University of Michigan Law School, tagreen@umich.edu

Follow this and additional works at: https://repository.law.umich.edu/articles

Part of the Common Law Commons, Criminal Law Commons, and the Legal History Commons

\section{Recommended Citation}

Green, Thomas A. "The Jury and the English Law of Homicide, 1200-1600." Mich. L. Rev. 74 (1976): 413-99.

This Article is brought to you for free and open access by the Faculty Scholarship at University of Michigan Law School Scholarship Repository. It has been accepted for inclusion in Articles by an authorized administrator of University of Michigan Law School Scholarship Repository. For more information, please contact

mlaw.repository@umich.edu. 


\title{
THE JURY AND THE ENGLISH LAW OF HOMICIDE, 1200-1600
}

\author{
Thomas A. Green
}

\section{TABLE OF CONTENTS}

I. INTRODUCTION: THE Historical BACKGROUND

II. The TRIal JuRy and the LAW OF Nonfelonious HomiCIDE IN THE FOURTEENTH CENTURY
A. Homicide in Self-Defense 428
B. Justifiable Homicide 436
C. Accidental Homicide 444
D. Jury Behavior and the Judicial Response 452

III. The Statute of 1390: AN ANalysis of the Inttiative FOR CHANGE IN THE LAW OF FeLoNious Homicide

A. The Pardon Statutes 457

B. The Statute of 1390 and the Jury 469

IV. The TUdor Transformation IN the LaW OF Homicide 472

A. The Murder-Manslaughter Distinction _._________ 473

B. Instruments of Change in the Law of Homicide .... 487

V. CONCLUSION 497 


\section{THE JURY AND THE ENGLISH LAW OF HOMICIDE, 1200-1600}

\section{Thomas A. Green"}

$T^{\mathrm{T}}$ HE early English jury was self-informing and composed of persons supposed to have first-hand knowledge of the events and persons in question. The judge instructed the jury on the law, but was himself almost entirely dependent upon the jury for his knowledge of the case. By stating the evidence in a way that made the result it wanted a necessary conclusion, the medieval jury was able to alter the impact of formal rules of law to conform with prevailing social attitudes.

I have demonstrated elsewhere that before there emerged a judicial distinction between murder and noncapital manslaughter, juries employed this power to prevent the execution of certain kinds of slayers. I suggest in the present article that this pattern of jury behavior had significant effects on the development of the law of homicide from c. 1200 to 1550 . It tended to hide those close and difficult cases that, had they come forward, might have forced the bench to refine the law of homicide, and, in a curious manner, it produced rigid adherence by bench and legislature to the older strict rules.

At the beginning of the thirteenth century and for some time thereafter, the formal law of homicide was rigidly bifurcated. While there existed a narrow category of nonfelonious slayings (that is, slayings that led to acquittal or royal pardon), the vast majority of

* Associate Professor of Law, University of Michigan. B.A. 1961, Columbia University; Ph.D. 1970, Harvard University; J.D. 1972, Harvard University.—Ed.

† I would like to thank the staff of the Public Record Office, London, England, for their invaluable service. I am especially indebted to R.F. Hunnisett and D.G. Clark of the Record Office. Dr. John Baker of Cambridge University and Professor James S. Cockburn of the University of Maryland extended helpful advice on several important aspects of this article. Three research assistants contributed significantly to the preparation of this article: Rita Burns, Jean Prchlik, and Linda Schwartzstein. I am also very grateful to Professors Charles Donahue, Richard Lempert, and Peter Westen of The University of Michigan Law School, to Professors Morris Arnold of Indiana University Law School, John Langbein of The University of Chicago Law School, and Stephen White of Wesleyan University, and to Ruth Brownell Green for their helpful comments on earlier drafts of this article. Finally, I would like to express my appreciation to the William W. Cook Endowment Fund for its generous financial support.

Quotations from foreign-language sources have been translated by the author unless otherwise indicated. Spelling and punctuation of English sources have been modernized. 
homicides, including what today we would call manslaughters, were considered capital offenses. In part I of this article, I shall briefly set forth the history of this legal distinction, contrast it with medieval community attitudes toward homicide, and describe the means by which the community was able to bring its sentiments to bear on the criminal justice system.

In part II, I shall examine in somewhat greater detail the early law of nonfelonious homicide and set forth the evidence supporting the proposition that medieval juries frequently manipulated this area of the law. I shall argue that this jury manipulation significantly affected the growth of the substantive law of homicide-stunting it in some ways and causing it to develop in an inconsistent manner in others.

While there was relatively little development in the law of homicide before the sixteenth century, there was one important initiative for change in the late fourteenth century. That initiative, which I shall analyze in part III, was Parliament's attempt to set limits on the royal prerogative to pardon for felonious homicide, a legislative program that led to a temporary distinction between "murder" and less serious forms of felonious homicide (i.e., "simple" homicide). For reasons set forth, that distinction did not produce a change in the substantive law of homicide.

The sixteenth-century reform of the institution of benefit of clergy produced the main outlines of the modern law of homicide. That development in the substantive law depended on both the specific procedural context in which benefit of clergy was pleaded and the new role that the trial jury had by then come to play. In part IV, I shall analyze those developments in order to demonstrate how, after several centuries of discontinuity between formal rules and community attitudes, the rules were finally reconciled with public sentiment in the modern law of homicide.

\section{INTRODUCTION: THE HISTORICAL BACKGROUND}

Homicide was a daily fact of life in medieval England. Brawling was common; serious physical violence routine. ${ }^{1}$ Provocation produced retaliation, often by knife or staff, and relatively superficial blows sometimes resulted in death from ensuing shock or infection. Then, as now, much of the violence that proved fatal grew out of sudden fights between neighbors or relatives. Other homicides, however, were committed in cold blood, for example, in the course of

1. B. Hannawalt, Violent Death in Fourteenth and Fifteenth.Century England 78 (forthcoming in J. FOR THE COMP. STUDY OF Soc. \& HIST.). 
settling an old grudge. The slayer in such a case sought to take his victim off-guard and to make death a certain result. Deliberate homicide was also perpetrated by members of roving gangs of thieves who accosted highway travelers or broke the calm of villages, burgling houses and slaying resisting residents or potential witnesses. ${ }^{2}$

These facts are not startling. Sudden wrath and murderous design have lain side by side in almost all societies. But the incidence of homicide may have been greater then than now: Poor medical techniques meant the injured often died; inadequate policing mechanisms encouraged those prone to a life of violent theft.

Nor is it startling that community attitudes distinguished between cold-blooded killing and slaying in the heat of passion. Certainly a distinction between intentional and unintentional homicide seems natural. Deaths in brawls often resulted from blows that were not intended to be fatal. Thus, it may have been difficult for community members to conceive of the slayer's act as truly deliberate. Those who sanctioned execution or retribution in the case of truly premeditated homicide might not sanction it for homicide perpetrated out of sudden anger. The execution of those who slew of a sudden would have meant not only a dramatic increase in the numbers sent to death, but also the frequent condemnation of neighbors and friends, persons of generally good reputation. In medieval England, as I have argued elsewhere, the local community considered the drastic sanctions appropriate mainly for the real evildoer: the stealthy slayer who took his victim by surprise and without provocation. ${ }^{3}$

This distinction between slaying by stealth and slaying openly and of a sudden was embedded in Anglo-Saxon criminal law and survived after the Conquest at least until the middle of the twelfth century. Capital punishment was reserved for only the former. ${ }^{4}$ Though little is known about the exact scope of "slaying by stealth," it surely included killing by poison and possibly by ambush or other forms of surprise attack. ${ }^{5}$ These were "botless," or unemendable crimes; that

2. See note 173 infra.

3. See Green, Societal Concepts of Criminal Liability for Homicide in Medieval England, 47 SPECULUM 669, 689-93 (1972).

4. N. HuRnard, The King's Pardon for Homicide 1 (1969).

5. See Green, supra note 3, at 689 (footnotes omitted):

Originally, murder was "secret" in the narrow sense that slayer hid his victim's body to conceal the deed, but it probably was soon used more broadly to refer to any homicide whose perpetrator was unknown. ... It is likely, however, that murder already in Anglo-Saxon times might have referred to the fact that the slayer's identity was concealed from his victim, so that the latter was taken offguard.

See also 2 F. Pollock \& F. Maitl.ANd, The History of English LAw 486 (2d ed. 1968); Kaye, Early History of Murder and Manslaughter (pts. 1 \& 2), 83 L.Q. REv. 365, 571, at 366-67 (1967); Pollock, The King's Peace in the Middle Ages, 13 Harv. 
is, they could not be remedied through the payment of compensation (bot) by the slayer or his kin to the kin of the slain. ${ }^{\circ}$

With the exception of these unemendable homicides, or "murders," slaying was a matter for compensation. " The rules governing compensation were, within a century of the Anglo-Saxon invasion of England, already embodied in the dooms, "legislation" declaring social custom. ${ }^{8}$ The earliest dooms merely recorded the levels of compensation; later dooms established the local pretrial and trial procedures required before compensation could be adjudged in a given case. ${ }^{9}$ Failure to stand to justice or, thereafter, to pay the required sum gave the slain person's kin the right to prosecute the feud and even to take the life of the slayer. ${ }^{10}$ But it is likely that most slayings led to "composition," payment and re-establishment of relative harmony between kin groups. ${ }^{11}$

The legal distinction between these two types of homicide was obliterated in the course of the reforms of Henry II (1154-1189). ${ }^{12}$

L. Rev. 177 (1900), in 2 Select Essays in ANglo-American Legar History 403, 404 (1908).

6. See J. Goebel, Felony and Misdemeanor 381-82, 431 (1937); N. HuRnard, supra note 4, at 1-12; 2 F. Pollock \& F. MAITLAND, supra note 5, at 449-51.

7. While slaying through accident and self-defense were, in theory, emendable homicides for which compensation was owing, there is evidence of an attempt by king and Church in the tenth and eleventh centuries to limit the amount owed. Of the success or failure of these attempts we know nothing. It seems likely that the king, as fount of justice, employed his power to extend mercy to such slayers, at least to the extent of excusing the collateral payment to the Crown (the wite) owing in cases of emendable homicide. Pollock and Maitland state that the king might not insist upon the wite in cases of misadventure. 2 F. Pollock \& F. Martland, supra note 5 , at 483. Although self-defense might have been treated similarly, more likely it was treated as an ordinary intentional homicide. Only one Anglo-Saxon doom (that is, "legislation" declaring social custom) gives substantial consideration to mitigation, and it distinguishes between accident resulting from the slayer's negligence and accident resulting from the victim's carelessness. Alfred 36, in THE LAwS OF THE EARLIEST ENGLISH KINGS 79-81 (F. Attenborough trans. \& ed.) [hereinafter Attenborough]. See N. HuRNard, supra note 4, at xiii-xiv. For a discussion of the influence of the Church on criminal liability in the tenth and eleventh centuries, see Whitelocke, Wulfstan and the Laws of Cnut, 63 ENG. HIsT. REv. 433 (1948).

8. See generally Attenborough, supra note 7; 1 F. LIEBERMANN, Die Gesetze DER ANGelsachsen (1903); H. RICHARDSON \& G. SAYLES, LAW AND LEgislation FROM AETHELBEHRT TO MAGNA CARTA 1-29 (1966).

9. Compare the laws of Aethelberht, in Attenborough, supra note 7, at 4, with the laws of Alfred, in $i d$. at 63.

10. See Alfred 42, in Attenborough, supra note 7, at 83-85.

11. We shall never be certain as to the relative frequency of composition and blood-feud. One scholar suggests that feuding continued after Alfred's time (the late ninth century), perhaps into the eleventh century. See D. WHITELOCKE, THE BeGiNNINGS OF ENGLISH SOCIETY 38-45 (1965). The evidence of some continued feuding, however, does not preclude a general pattern of composition. By the twelfth century, it seems fair to say, the attitude of the community, if not that of the kin of the slain, was that compensation was appropriate in cases of nonstealthy homicide.

12. On the legal reforms of Henry II, see, e.g., H. Richardson \& G. SAYLES, The 
Whatever the real ends of monarchical policy-deterrence, financial gain, or political centralization-the Angevin reform of the criminal law established a system of substantive law that was sharply at odds with prevailing social practices. The sudden twelfth-century growth in royal criminal law, in theory implementing the ancient royal obligation to enforce the king's peace throughout the land, ${ }^{13}$ was principally a jurisdictional development. Henry II effected this development by ordering his justices to ride circuit and his local officials to produce before those justices good and loyal men of the county who had knowledge of recent felonies and other, lesser, breaches of the king's peace. ${ }^{14}$ The justices heard the accusations, or "presentments," of these embryonic grand juries, ordered the sheriff to arrest suspects named in the presentments, and put to trial suspects already arrested. As had formerly been the case in the local county courts, felony trials proceeded by way of ordeal. ${ }^{15}$ Those found guilty through this ancient method of proof, however, were now to be hanged. ${ }^{16}$ The growth of royal jurisdiction over all felonies and the consequent imposition in these cases of the blood sanction blurred the former distinctions among felonies. No longer were there botless and emendable felonies; all were capital. ${ }^{17}$

Governance of Mediaeval England from the Conquest to Magna Carta 251300 (1963); R. Van Caenegem, The Birth of the ENGlish Common LAw 40.41, 72-75 (1973).

- 13. See generally J. GoEber, supra note 6, at 423-40; H. Richardson \& G. SAYLES, supra note 12, at 173-215; D. STENTON, ENGLISH JUSTICE BETWEEN THE NoRMAN CONQUEST AND THE GREAT ChaRTER 1066-1215, at 65-82 (1964); Hurnard, The Jury of Presentment and the Assize of Clarendon, 56 ENG. Hist. Rev. 374 (1941).

14. Assize of Clarendon (1166) in Sources of ENGLish Constitumonar HisToRY 76, 77 (C. Stephenson \& F. Marcham trans. \& eds. 1937) [hereinafter Assize of Clarendon]. The Assize of Clarendon may have consolidated and enhanced earlier practices. Hurnard argues that the system of communal accusation had its roots in the early twelfth century, if not before. Hurnard, supra note 13, at 378 96. As a practical matter, Henry $I I$ appears to have made such sporadic practices routine.

15. Assize of Clarendon, supra note 14, at 77. For discussion of the ordeals in the twelfth century, see R. VAN CAENEGEM, supra note 12, at 62-68.

16. According to the Assize of Northampton (1176), those who failed the ordeals to which they had been subjected pursuant to the Assize of Clarendon lost a foot. Hurnard, supra note 13 , at 396 . The death penalty eventually replaced mutilation; for homicide this may have happened during the reign of Henry II. See F. POLLOCK \& F. MAITLAND, supra note 5, at 461.

17. See 2 F. PoLLOCK \& F. MAITLAND, supra note 5, at 458-60. Hurnard suggests that many felonies, including some homicides, had become unemendable as early as the reign of Henry I (1100-1135). N. HuRNARD, supra note 4, at 8-9. The king's peace was extended to cover slayings that occurred at specified places or on certain occasions. Thus, in Hurnard's view, the reforms effected by Henry II represented a coalescence of earlier, piecemeal extensions of the king's peace. While this militates against a very sudden change in the law of homicide, it does not materially affect the argument I am setting forth. 
The felonies over which the royal justices had jurisdiction included, of course, homicide. Though felonious homicide soon came to be defined as slaying through malice (malitia, malitia precogitata), "malice" stood only for a threshold degree of mens rea, not for true malice aforethought. ${ }^{18}$ Within this category, then, as within the entire class of felony, the old distinction between botless and emendable acts disappeared. All felonious homicide was considered capital. ${ }^{10}$

There were now two main categories of nonfelonious homicide: justifiable homicide and excusable homicide. Though these categories did not become firmly established until the early thirteenth century, it is likely that they took form during the reign of Henry II and his immediate successor. ${ }^{20}$ The category of justifiable homicide included executions pursuant to a royal order and the ancient practices of slaying thieves caught escaping with the goods and outlaws who resisted capture. ${ }^{21}$ Slayers deemed justified were acquitted by the royal courts.

Excusable homicide, on the other hand, did not lead to acquittal; rather the slayer was required to obtain a royal pardon, which absolved him from liability to royal suit but left open, at least in theory, the right of the victim's kin to prosecute an appeal. ${ }^{22}$ There were two

18. See Kaye, supra note 5 , at 371-77. Of course, the king, exercising his discretion, might pardon some who had committed felonious homicide. See notes 52-55 infra and accompanying text.

19. The term "murder" was no longer commonly employed as a term of art for particularly heinous homicide. But the concept of murder was reflected in the name given to the fine imposed on the local community for an unexplained homicide ("murdrum"). Many, but not all, such homicides had been committed in secret, the slayer taking his victim by surprise and making his escape without detection by third parties. See T. Plucknett, A Concise History of the Common LAw 88, 444-45 (5th ed. 1956); Crown Pleas of the Wirtshire Eyre, 1249, at 61-65 (C. Meekings trans. \& ed. 1961) [hereinafter WILTSHIRE EYRE]; Hurnard, supra note 13, at 385 93. The murdrum fine was abolished in 1340.14 Edw. 3, stat. 1, c. 4 . By that time, the term "murder" was once again coming to be identified in official documents with slaying itself. See, e.g., Post, Some Limitations of the Medieval Peace Rolls, 4 J. Soc. of ARCHIVISTs 633, 639 (1973). See note 175 infra and accompanying text.

20. There is some, but slight, evidence that as early as the reign of Henry I, slaying in self-defense did not lead to payment of the wergild. Nevertheless, the defendant had to make "honorable amends" ("dignis satisfactionibus hoc monstrare liceat"). Leges Henricr Primi c. 87, at 6 (L. Downer trans. \& ed. 1972).

21. See authorities cited in notes 84-86 infra.

22. The appeal was a form of private prosecution. By the late twrelfth century, it involved a suit in a royal court leading to trial by battle. In the case of homicide, only certain close relatives could bring an appeal, and the charges had formally to be lodged in very specific terms. The system of presentment instituted by Henry II provided an alternative and, from the point of view of the royal justices, preferable method of trial. Especially after trial by jury became common, the number of successful appeals declined rapidly. Judges frequently quashed appeals and held the appellee for trial by jury at the suit of the king. See generally R. HUNNISETT, THE 
main classes of excusable homicide: accidental homicide ${ }^{23}$ and homicide committed in self-defense. ${ }^{24}$ Accidental homicide was unintentional homicide: The slayer had not intended to slay (or, we may suppose, seriously to harm) the deceased. The category thus encompassed negligent acts or even reckless ones. ${ }^{25}$ The category of selfdefense was an extremely important one; except for the very narrow class of justifiable homicide, it represented the sole body of intentional homicides that were nonfelonious and hence not punishable by death. By the early thirteenth century, this crucial category had come to be defined as slaying out of literally vital necessity: the slayer, under mortal attack, had acted as a last resort to save his own life.

In an age when fighting was common and death could result from even a superficial wound, the new rules of homicide must have clashed with community instincts about just deserts. Many slayings occurred within the small village community, ${ }^{28}$ and, had the formal rules been successfully implemented, many persons would have been hanged who, under earlier rules, would have been allowed to compose with the kin of the slain. It is therefore surprising that for four centuries, from the time the Crown took jurisdiction over all felonies until the middle of the sixteenth century, the legal distinction between felonious and nonfelonious homicide remained fixed and all felonious

Medieval Coroner 55-65 (1961); Placita Corone xxiv-xxviii (J.M. Kaye trans. \& ed. 1966) [hereinafter Placita CORONE]; Wiltshire EYRE, supra note 19, at 69-81. Hurnard develops a brilliant argument linking the institution of private appeals to the origin of the system of pardoning perpetrators of excusable homicide. See N. HuRNARD, supra note 4, at 1-30. Her argument assumes that homicides committed in self-defense and by accident had traditionally led to a valid claim for compensation. The king could not easily abolish the right to such compensation and determined to allow appeals to continue in such cases. But it would have been dangerous to assert the principle that these homicides did not have to be presented at all: presenting juries might then conceal homicides at an early stage by declaring them outside of royal concern. The kin of the slain, for their part, might even try to characterize felonious homicides as killings in self-defense or through accident so that they could press an appeal leading to compensation. Thus, all homicides had to be presented; where the royal justices found no liability, a royal pardon, reserving to kin their right to appeal, was granted. Such appeals were in fact very rarely if ever, successful, and it is doubtful whether as a matter of law they could be brought after 1250. See id. at 204; Placita Corone, supra, at xxxii.

23. See text at notes 115-34 infra.

24. See text at notes 56-81 infra. A third small category of excusable homicide, not discussed in this essay, was slaying excused by insanity. On this subject, see $\mathbf{N}$. HURNARD, supra note 4, at 152-70; N. WALKER, 1 CRIME AND INSANITY IN ENGLAND 15-51 (1968).

25. See note 115 infra and accompanying text.

26. With regard to the fourteenth and fifteenth centuries, see B. Hannawalt, supra note 1, at 15-16. Comparable studies do not exist for the late twelfth and thirteenth centuries, but there is no reason to believe that homicides became more local in the ensuing period than they had been before. 
homicide remained capital. For the stealthy slayer and for the one who acted on sudden impulse, the official sanction was the same.

Why did the distinction between capital and noncapital felonious homicide remain submerged for so long? Why did it finally emerge when it did, and what dictated the form that it took? It is my thesis that the pace and nature of the development of the substantive law of homicide was heavily influenced by the interaction of the self-informing jury and the medieval pardoning system. Hence these institutions and procedures require discussion.

It is important to recognize that from its very inception the new system of criminal law both compelled and depended upon widespread lay cooperation. After the Assize of Clarendon in 1166, presentment depended upon the cooperation of men of the hundredal divisions of the counties. These men were supposed to present not only those whom they suspected on the basis of their own knowledge, but also those who were suspected generally in the hundred. ${ }^{27}$ In some cases, therefore, the presentments reflected the jurors' own willingness to accuse; in others, they reflected the willingness to accuse of other, perhaps less substantial, members of the community.

For a half century the suspect, once presented, was at the mercy of those who oversaw the ordeals. After the ordeals were abolished in $1215,{ }^{28}$ however, the Crown, in search of a new method of proof, turned once again to lay cooperation. If the defendant agreed to "put himself on the country," a lay jury of twelve rendered a verdict as to his guilt or innocence. ${ }^{29}$ This petty or trial jury, including at first members of the presentment jury, was sworn to state whether the defendant had in fact committed the felony for which he had been presented. Thus, from the third decade of the thirteenth century, both presentment (or indictment, as a somewhat different version of the process came later to be called) and the verdict of the "country" stood between the accused and the gallows. By then, it would seem,

27. Assize of Clarendon, supra note 14, at 77 ("whether in their hundred or in their vill there is any man accused or publicly known as a robber or murderer or thief ..."). In theory there was no room for discretion of the sort usually associated with a grand jury; this jury was a reporting body. Failure to report anyone suspected of any acts specified in the bill of the eyre could result in a fine, or "amercement." See WILTSHIRE EYRE, supra note 19, at 92-93.

28. By an order of the Fourth Lateran Council of 1215, clergy were prohibited from playing any role in the ordeals, which had depended upon religious sanction. See T. Plucknetr, supra note 19, at 118-19; R. VAN CAENEGEM, supra note 12, at 69.

29. See S. Milsom, Historical Foundations of the Common Law 358-60 (1969); T. PlUCKNETT, supra note 19, at 118-21; Maitland, Introduction to PleAs OF THE CROWN FOR THE COUNTY OF GLOUCESTER at xxxvi-xli (F. Maitland ed. 1884) [hereinafter PLEAS of Groucester]; Stenton, Introduction to RoLIS OF THE Justices IN EYRE at lxviii-lxxi (D. Stenton trans. \& ed. 1934). 
the opportunity existed for the community to impose its own views within and upon the legal process.

A review of the procedures involved from the time of the slaying until the final resolution of the case reveals the manner in which such community sentiment might be expressed. In all homicide cases, the coroner, a Crown official at the county level, was required to hold an inquest as soon as possible. ${ }^{30}$ Usually within a day or two of the discovery of the body, ${ }^{31}$ the coroner assembled the inquest jury, composed of representatives of the vill in which the slaying occurred and of several neighboring vills, ${ }^{32}$ and conducted the inquest. He there noted the cause of death, took down the names of suspects mentioned by the jurors, and ordered the sheriff or hundred bailiff to arrest the suspect if this had not already been done. ${ }^{33}$ The suspect was held for trial before the royal justices, whose circuits or "eyres" were held infrequently throughout the thirteenth century. From early in the fourteenth century, the itinerant royal justices came twice yearly to the county town for delivery of its gaol. ${ }^{34}$ A record of the coroner's inquest was available to the court, as was the record of any presentment made either before the royal justices or before the justices of the peace. ${ }^{35}$

Typically, at gaol delivery, the suspect being held for trial was brought forward by the sheriff. The justices inquired about the charges, and the sheriff, presumably relying on the enrollment of the

30. R. HUNNISETT, supra note 22 , at 13 .

31. Id.

32. Id. at 13-14.

33. 1 d. at 22 .

34. See generally R. PUGH, IMPRISONMENT IN MEDIEval ENGLAND 255-314 (1968). Until the late thirteenth century, judicial business was transacted mainly at the eyres, plenary judicial circuits held at seven-year intervals to deal with civil pleas, criminal cases ("pleas of the crown"), and various administrative and economic matters. See generally WILTSHIRE EYRE, supra note 19. Because of the infrequency of the eyres, incarcerated homicide defendants frequently obtained orders for special inquisitions into the circumstances of the alleged slaying. Upon a finding of excusable homicide the defendant might be either pardoned or bailed until the next eyre. See R. HunNISETT, supra note 22, at 77-78; N. HURNARd, supra note 4, at 3742; text at notes 75-76 infra. This article will be concerned chiefly with gaol deliv. ery, the main context of fourteenth-century felony trials. There is no printed edition of selected gaol delivery rolls. The rolls are described and discussed in M. Gollancz, The System of Gaol Delivery (unpublished M.A. dissertation, University of London, 1936). All of the extant rolls are deposited at the Public Record Office, London, England.

35. On the justices of the peace, see T. PluckNeTt, supra note 19, at 167-69; Harding, Origins and Early History of the Keeper of the Peace, 10 Transactions of tHe Royal Hist. Soc. 85 (5th series 1960). Proceedings Before tHe Justices of the Peace in the Fourteenth and Fifteenth Centuries xxvi, lv, xciv (B. Putnam ed. 1938) [hereinafter ProceEdings], discusses the sending of indictments by justices of the peace to justices of gaol delivery. Many of the gaol delivery enrollments after 1350 include indictments made before justices of the peace. 
coroner or justice of the peace, ${ }^{36}$ stated the charges to the court. ${ }^{37}$ The defendant was then asked how he pleaded, and, in response to the almost invariable plea of not guilty, the bench ordered that the jury be selected and sworn. ${ }^{38}$ The twelve trial jurymen generally came from the hundred where the homicide had taken place. ${ }^{39}$ Until the late thirteenth century they were drawn from the grand jurors; ${ }^{40}$ subsequently they were chosen from a group of eighteen sent by each hundred to sit on all trials relating to that county subdivision. ${ }^{41}$ Close relatives $^{42}$ of the deceased were excluded, as were those known to bear a grudge against him; ;3 $^{3}$ with these two exceptions, familiarity with the facts of the case was a desideratum rather than a bar to jury service.

The surviving trial rolls record the selection of a jury and, in the next sentence, the jury's verdict. Except in cases of excusable homicide, where details of the accident or act of self-defense were enrolled, the verdict was generally recorded solely in the conclusory terms of guilt or innocence. The enrollments do not often reveal where the

36. It is possible that the sheriff relied on a highly abbreviated form of the presentment or indictment that had been set forth in the order from the coroner or justice of the peace that the suspect be taken.

37. See, e.g., Plactia Corone, supra note 22, at 19. Cf. J. Bellamy, Crime and Public Order in England in the Later Middle Ages 146 (1973) ("TT]he indictment was read out").

38. See, e.g., JuST 3/1-400, passim.

39. Pugh studied the gaol delivery rolls for Newgate Prison, in London, during the reign of Edward I (1272-1307). Pugh, Some Reflections of a Medieval Criminologist, 59 ProceEdINGS OF THE BRITISH ACADEMY 1 (1973). On the basis of this study, he concluded that juries usually included representatives of the place where the alleged offense had been committed, and he states:

Generally this was secured, and when charges were laid in two or more venues

all the venues were summoned. Besides this, surrounding venues might be added

-a reflection perhaps of the "four neighbouring towns" normally assembled after

presentments in eyre. This was, in some years at least, particularly true of the

London wards. Thus full coverage of the site venue was assured. In addition,

however, there are many instances where the suspect's home venue, or what looks

like it, was added to the site venue. Besides the site and home venues a jury

might also come from the venue where the felon was arrested, which could be

far from the scene of the crime. ... Finally, in order to prove an alibi, juries Id. at 13 .

40. T. Plucknetr, supra note 19, at 126. Plucknett suggests that, as of the middle of the thirteenth century, petty juries commonly had among their number some who had been on the presenting jury, although it is unlikely that juries were composed solely of presenters. Before 1352, a defendant was not able to challenge a member of the petty jury on the ground that he had served on the grand jury. Id. at 127.

41. See, e.g., C 260/4, no. 19 (1288); C 260/6, no. 7 (1292); C 260/16, no. 12 (1306).

42. J. BeLLAMY, supra note 37 , at $145-46$.

43. 2 H. Bracton, on the Laws and Customs of ENGLAND 405 (S. Thorne trans. \& ed. 1968) (f. 143b). 
jury got its information or how it reached its verdict. One obvious source of information was the defendant. Though his statement was not recorded, there is evidence that, after denying his guilt, the defendant generally related an alibi or admitted having slain the deceased and explained how he had acted in self-defense. The judge apparently then questioned the defendant, who responded in terms calculated to save his own skin. ${ }^{44}$ The jury's opinion, however, may also have been based on what it had long known about either the homicide or the defendant, or on what it had just learned in the rumor mill of the gaol delivery session. ${ }^{45}$ It was the jurors' duty to render a verdict on the basis of their knowledge of the facts, whether that knowledge was first-hand or gleaned from those whom they chose to believe. They were gatherers as well as weighers of evidence, and their sworn verdict regarding the facts was determinative. Though the judges might occasionally pause to question the jury, ${ }^{40}$ in all but unusual cases the jury firmly reiterated its verdict and thereby ended the matter. Judgment was thereupon entered by the court in stark formulae: for acquittal, "quietus est"; for conviction, "suspendatus est" ("he is hanged"); for excusable homicide, "remittitur ad gratiam domine regis" ("he is remitted to the grace of the king").

It is clear that the trial jury possessed the power to state the verdict in a form that compelled the judgment it believed the defendant deserved. The jury could produce a verdict of clear-cut malicious homicide; it could absolve the defendant of all liability by stating either that he had not committed the act or that he had committed it in the course of taking a felon; it could state that the defendant slew by accident or in self-defense. The jury's choice of

44. See, e.g., Placrta CoRone, supra note 22, at 19-20. J.M. Kaye, the editor of Placita Corone, describes the procedure in cases on indictment as "inquisitorial": "[T] he justice conducts the case in person as an examination in chief, seeking to induce each prisoner either to confess or to put himself upon a jury." Id. at xxxv. Kaye asserts that the justices were not above tricking the defendant where they could do so. Id. But the successful tricking of defendants into admissions of guilt must have been very rare; the trial rolls reflect the fact that very few defendants ever confessed. The one example of an indictment for homicide in Placita Corone led to a verdict of self-defense, and it demonstrates how easily the defendant and jury could deter the bench from having its way with the defendant. Id. at 19-20.

45. Jurors were sworn to tell the truth "to the best of their knowledge. If, however, they did not know it or possessed imperfect knowledge they could not then support the prosecution, for they must not reach their verdicts on the basis of mere "thoughts." " Pugh, supra note 39, at 17-18. It is doubtful, however, that jurors could swear only to what they had themselves witnessed. Presumably, they had to have become convinced to the point of virtual certainty, but we cannot determine by what standards they were to assess the evidence and testimony brought to their attention before or during trial.

46. The evidence on this point, however, is by no means clear. See N. HuRNARD, supra note 4 , at 258. 
verdict, its concept of the defendant's liability, did not have to square with the formal rules of the law. Even if the bench suspected that juries took advantage of their evidence-gathering role in this way, the justices had no means in any given case for getting behind the jury's formulistic verdict to the truth of the matter. ${ }^{47}$

If convicted, the defendant was hanged, usually within a matter of hours and nearly always within several days. His lands and goods were forfeited. ${ }^{48}$ The acquitted defendant was immediately released, though he, too, suffered forfeiture of goods if initially he had fled from justice. ${ }^{40}$ A finding of excusable homicide resulted in the defendant's remand to gaol until he obtained a pardon from the king, a procedure that delayed his release for several months. ${ }^{50}$ Until the 1340 's, the excusable slayer, like the acquitted defendant, suffered forfeiture only if he had refused to surrender upon first becoming a suspect. Thereafter, forfeiture of goods became automatic in such cases; it had in effect become a penalty attached to the pardon for accidental homicide or homicide in self-defense. ${ }^{51}$

47. See, e.g., Placita Corone, supra note 22, at 19-20. The procedure of "attaint" of the jury "was never extended to the criminal jury . . . ." S. MrLsoM, supra note 29 , at 366 . Judges could threaten juries with fines and imprisonment, but it is difficult to see how these could have been used in "suspicious" self-defense cases: too many such cases occurred, and the medieval bench lacked a source of evidence against which to test the juries' verdicts. In the great majority of cases, the coroner's or justice of the peace's indictment was too spare to provide the bench with an alternative to the jury's recitation of the facts.

48. Escheat of lands was to the feudal lord except in cases of high treason where escheat was to the king. Forfeiture of chattels was to the Crown. S. MrLsom, supra note 29 , at 370 .

49. N. HuRNARD, supra note 4, at 144-45. It is not clear from the trial rolls how often the court put to the jury the question whether or not the defendant had fled. See note 51 infra.

50. T. Green, Pardonable Homicide in Medieval England, Dec. 1, 1969, at 170 (unpublished dissertation, Harvard University).

It appears that at least by the late fourteenth century, some defendants were released to the custody of trustworthy persons (a procedure known as mainprise) pending their receipt of the pardon. The gaol delivery rolls indicate that some justices "mainperned" pardonables who were able to find four "gentlemen" from the county to stand as sureties. There is some Year Book support for this procedure as early as 1330. See A. Fitzanerbert, LA Graunde Abridgement, Corone, pl. 361 (1329) (1565). The earliest such enrolled cases, however, date from the mid-1340's. See, e.g., Jusr 3/134, m.24/4, m.24d/3 (1347). Nearly all the other enrolled cases showing release until pardon date from 1370 and after. See, e.g., Just 3/156, m.10/4 (1370); JUST 3/161, m.18/2, /3 (1375); C 260/103, no. 30 (1391); Just $3 / 179$, m.21d/9 (1397). The defendant was released after trial, "so that he might in the meantime seek the king's grace," and, theoretically, he was bound to appear at succeeding deliveries until the pardon had been received, claimed, and formally proclained.

51. N. HuRNard, supra note 4, at 147. See generally 2 F. Pollock \& F. MarTLAND, supra note 5 , at 481 . It is not possible to determine the exact moment this new policy came into being. The first Year Book reference to a general rule of forfeiture is Y.B. Hil. 21 Edw. 3, pl. 23 (1347). See also Y.B. Mich. 44 Edw. 3, pl. 
Until the thirteenth century, pardon in cases of excusable homicide was a matter of royal discretion; by the end of that century, it had become in practice a matter of the common law, ${ }^{52}$ issuing automatically and gratuitously,,$^{53}$ as a matter "of course" (de cursu). In contrast, pardons in all other cases of homicide were and remained true acts of discretion. These pardons "of grace" (de gratia) were granted in theory out of mercy, but in fact often as a political favor or for revenue. From the 1290 's on, they were employed openly as a

55 (1370); Y.B. Easter 2 Hen. 4, pl. 6 (1400). Examination of the gaol delivery rolls yields very uncertain information. Clerks did not always record forfeitures, and, even before 1340, they often failed to note flight. Recording flight was unnecessary before forfeiture became general: where forfeiture was indicated there must have been flight. Afterward, since flight was no longer a prerequisite for seizure of goods, it was an equally purposeless point for the busy clerks to make. Hence, neither the failure to indicate forfeiture nor the indication of forfeiture without mention of flight necessarily indicates whether the automatic forfeiture rule was in effect. For gaol delivery rolls evidencing the haphazard application of the new rule, see Just $3 / 129$ (1336-1346); JUST 3/131 (1337-1355); JUST 3/134 (1341-1351), passim. See note 158 infra and accompanying text.

52. N. HuRNARD, supra note 4 , at 224 . The source of the pardon was the royal prerogative, a power and a duty combined. As the fount of justice, the king was expected to do justice or to extend mercy wherever warranted. See H. BrACToN, supra note 43, at 378 ("[The king] is sometimes bound to grant his life to a man of grace, as where he has killed a man by misadventure, or in self-defense . . ." (emphasis added; footnotes omitted)). See also 2 FLETA 61 (H. Richardson \& G. Sayles trans. \& eds. 1955) [hereinafter FLETA].

A 1329 Year Book statement reflects the automatic nature of pardons: "Note that when a man is acquitted before the justices errant for the death of a man in selfdefense [soy defendo], the process is such, that he shall have the writ of the Chief Justice, within which writ shall be contained the record of his acquittal to the Chancellor, who shall make him his writ of pardon without speaking to the king by course of law." A. FITZHERBERT, supra note 50, Corone, pl. 361. (All quotations from the Year Books have been translated from the original Law French.) Cf. id., pl. 295 (1330): "Scrope, C.J., and the other justices ordered the prisoner to remove the record into the Chancery; and the Chancellor made him a charter in such a case without speaking to the king." Compare the Commons' petition to the king and the latter's reply in 1309. 1 Rotul PARLIAMENTORUM 444b; note 162 infra.

53. See 3 J. Stephen, History of Criminal Law of England 38 (1883), suggesting that the king granted pardons to those who slew in self-defense and misadventure "upon terms as to fines and forfeitures which would depend on the degree of blame which might be considered to attach to the defendant by reason of the avoidable nature of the necessity under which he had killed the deceased, if the case was one of self-defense; or the amount of carelessness he had shown if the case was one of accident." Although this may have been true during the early thirteenth century, the records are too sparse for a conclusion to be drawn on this point. The available evidence does suggest that this was only rarely the case after 1250 , when special inquisitions were held in large numbers. The verdicts in self-defense cases, especially, were phrased in a way that did not allow for blame to "attach to the defendant." Certainly this is true for fourteenth-century gaol delivery enrollments. Payment (not, however, depending upon "degree of blame") was sometimes required for special inquisitions and pardons in cases of excusable homicide in the thirteenth century. N. HURNARD, supra note 4, at 41-42. By the fourteenth century, only formal proclamation of the pardon was likely to require a fee, and this was not a necessary procedure. Id. at 65 . 
means of raising a military force. ${ }^{54}$ Pardons of grace immunized the recipient from prosecution for felony. They almost always issued before trial, and they prevented further proceedings. ${ }^{55}$ They could not easily be obtained after conviction, except by those rich or powerful enough to buy time to approach the king.

Defendants who were known to have committed felonious homicide (especially those who had committed "simple" homicide), but who had not obtained pardons of grace before being brought forward at trial, might still hope to be the beneficiaries of community sentiment. Because medieval juries in homicide cases might employ their de facto power to present the evidence in the form they pleased, defendants might be acquitted or they might be found to have slain in an excusable manner. In treating such defendants in this way, juries would be relieving the tension between community sentiments and the formal rules of the law. They would also, however, be shaping the development of the formal law in ways they could not easily have foreseen.

\section{THE TRIAL JURY AND THE LAW OF}

\section{Nonfelonious Homicide IN THE FouRTEENTH CENTURY}

In this section, I shall first set forth the evidence that medieval juries tended to characterize felonious but not especially heinous homicides as acts of self-defense. I shall then argue that this jury behavior affected the development of the law of nonfelonious homicide in at least three identifiable ways. First, this jury behavior was responsible in part for the retention of the strict legal rules defining self-defense. Second, judicial suspicion that juries manipulated the self-defense category led to an uneven development in the law of justifiable homicide: Although, in response to a perceived rise in professional crime, the category of justifiable homicide came to include slayers of those caught in the act of committing certain felonies, such as robbery or burglary, it did not come to include slayers of those engaged merely in personal assault. Third, jury behavior led to the retention of the royal pardon requirement and automatic forfeiture of goods for the category of self-defense long after courts began to acquit defendants in cases of accidental homicide. While true self-defenders may have deserved at least as much consideration as negligent or unwitting slayers, they continued to be treated harshly

54. See H. Hewtt, The Organization of War Under EDward III 29-31 (1966); N. HuRNARD, supra note 4, at 311-26.

55. Examination of four rolls showed that 40 out of 456 defendants produced pardons at trial. See JUST 3/137A (1351-1353); JUST 3/149, mm. 1-14 (1351-1366); JUST $3 / 142$ (1366-1371); JUST 3/167 (1377-1385) (homicide cases only). 
because the courts could not distinguish them from alleged "self-defenders" who had in fact committed felonious homicide.

\section{A. Homicide in Self-Defense}

The self-defense rules were among the least elastic of medieval criminal law. By the middle decades of the thirteenth century, the legal category of slaying in self-defense had been judicially formulated to include only acts of last resort, undertaken by persons who could not otherwise save their own lives. ${ }^{56}$ Moreover, the test was objective; it was not enough for the jury to agree that a defendant subjectively believed he had no other recourse. ${ }^{57}$

Jury verdicts soon came to include a formulistic response that the defendant "could not otherwise have escaped death" (recorded on the rolls, "aliter mortem suam non evadere potuit"). ${ }^{58}$ But the jury's initial assertion to this effect was not always sufficient. The trial rolls indicate that the justices sometimes questioned the jurors closely, particularly when the jury's original statement left unclear whether the defendant had in fact been placed in a position from which he could escape only through physical retaliation. ${ }^{50}$ In a few such cases

56. N. Hurnard, supra note 4, at 92-93. Hurnard's definitive discussion of the substantive and procedural elements of the law of excusable homicide in the thirteenth century has replaced all earlier studies. The present essay deals mainly with the period after 1300, with which Hurnard does not deal. For a critique of Hurnard's view that thirteenth-century excusable homicide verdicts were relatively truthful, see Green, supra note 3, at 683-86.

57. As late as 1454 , it was stated authoritatively by Justice Prisot:

[I]f a man assaults you in order to beat you it is not lawful for you to say you want to kill him and to endanger his life and limb: but if the case is such that he has you at such advantage that he intends to kill you as you seek to flee and he is swifter than you and pursues you so that you are unable to escape; or if you are on the ground under him; or if he chases you to a wall or hedge or dike, so that you cannot escape, then it is lawful for you to say that if he won't desist, you want to slay him to save your own life, and thus you may menace him for such special cause...

Y.B. Easter 33 Hen. 6, pl. 10 (1454).

In many, perhaps most, cases, physical obstacles to further retreat did not in fact exist. The assailant had endangered the defendant's life and retaliation probably seemed wiser than an attempt to flee. One judge admitted as much in 1414 when, after it had been remarked that the defendant was bound to attempt flight, Cokeyn added: "But I am not bound to wait while the other fellow lands a blow for perchance it will be too late." Y.B. Mich. 2 Hen. 6, f. 8, pl. 40 (1414).

58. See, e.g., C 260/13, no. 5 (1302); C 260/72, no. 38 (1361); C 260/79, no. 38 (1364).

59. See, e.g., C 260/7, no. 46A (1293). (All quotations from the trial rolls are translated from the original Latin.) In this case, the jurors stated that Gregory le Waleis threw Thomas de Gloucester "to the ground, lay upon him, and drew his knife desiring to kill him. Thomas, perceiving this, and fearing likewise his own death, drew his knife and struck Gregory as the latter lay upon Thomas' stomach." The justices then asked the jury whether in fact Thomas might have escaped without killing Gregory, to which the jury responded, "No, because Gregory lay upon Thomas' stomach and held him tightly and firmly to the ground" ("et ipsum strite 
the jurors responded that the defendant might have turned tail and outrun his assailant, an assertion that condemned the defendant. ${ }^{60}$ But in the vast majority of self-defense cases, including virtually all enrolled self-defense cases from the last quarter of the thirteenth century and beyond, the jury's first statement left no room for effective judicial challenge. Nearly every act of self-defense was said to have been undertaken by a cornered defendant; ditches, walls, and hedges had constrained fleeing defendants at every turn. ${ }^{61}$ Moreover, all juries, when questioned by the incredulous bench, tenaciously repeated these assertions.

et firmiter ad terram tenuit"). Their reply satisfied the court, and the defendant was remanded to prison to await his pardon. The pardon is recorded in CALENDAR OF THe Patent Rolis, 2 Edw. 1, at 40 (Oct. 11, 1293).

A similar example is found in C $260 / 6$, no. 28 (1292). The jurors stated that Gilbert, son of William de Cherneleye, struck Robert de Caterhale

upon the head with his bow so that the bow broke; and Gilbert struck him again with the remaining part of his bow. Robert, fleeing, sought to cross a ditch in which a hedge grew and in saving himself grasped a branch from the hedge which broke off so that he fell with the stick into the ditch. Gilbert soon arrived, assailing Robert with his fractured bow. Robert, considering this, struck back at Gilbert with the broken branch hitting him in the head so that he died. ...

The jurors were asked whether Gilbert had a sword or a knife and, if so, whether he had drawn either. When they replied that Gilbert was so armed, but had drawn neither weapon, the court, obviously doubtful as to the lethal nature of the broken bow, asked the jurors once again whether Robert could have escaped without slaying Gilbert. The jury reiterated their opinion that he could not have done so. This failed to satisfy the court, however, and only after a second jury had been impaneled and had supported the verdict of the original jury was the defendant awarded a special verdict. The enrollment indicates in a later hand that Gilbert was pardoned.

In a third case, $C 260 / 6$, no. 16 (1292), the petty jury stated that Alan de la More killed John Tyrel in self-defense after a great chase. The two had argued until John ran home to fetch a sword. "Alan, seeing John approaching, and desiring to evade John's malicious intent, kept himself underneath the horse his father, Robert, was riding. Robert did all in his power to prevent John from striking Alan, but John chased Alan into a certain corner . . . " where, as a last resort, Alan retaliated with a mortal blow. The court asked whether Alan could have fled before John returned from his house armed. The jury replied that the defendant could not have fled because John was faster than he ("Johannes erat celorior predicto Alano"). Compare C $260 / 23$, no. 23 (1332), where the jurors testified that the defendant fled as fast as he could ("velociori curru quo potuit"), but his assailants were even fleeter and caught up with him ("velociores demum ipsum . . . attinxerunt").

60. See, e.g., 43 LE LIVRE des AsSISES ET PLEAS DEL'CORONE EN TEMPS DU ROY EDWARD le TIERS, pl. 3 (1370) (1679) [hereinafter AssIZE].

61. See, e.g., C 260/13, no. 32 (1302) (wall); C 260/14, no. 10 (1302) (door); C 260/15, no. 18 (1305) (wall and ditch); C 260/85, no. 31 (1374) (between two hedges).

During the fourteenth century, enrollments of jury verdicts tell even more elaborate tales: The deceased had started an argument with the defendant, had struck him and wounded him severely, and the latter had retaliated with only one blow. See, e.g., Just 3/142, m.6d/2 (1366); Just 3/142, m.10d/2 (1370). These embellishments were not required by the law of self-defense, but juries set them forth in an effort to convince the bench that the defendant had met the basic requirements. They also convinced the bench that further questioning would not be fruitful. 
Verdicts of self-defense were not only elaborate and expressed in the most exculpatory terms, they were also extremely common. One gaol delivery roll covering the years 1351 to 1353 reveals that 21 (30 per cent) of 68 defendants in cases of homicide were found to have slain in self-defense; ${ }^{62}$ in the first section of another roll containing cases from the period 1351 to 1366,19 (59 per cent) of 32 homicide defendants were categorized as self-defenders; ${ }^{63}$ fifty-nine ( 37 per cent) of 157 homicide defendants on a roll from the years 1366 to 1371 were said to be self-defenders; ${ }^{64}$ and, on a roll from 1377 to 1385 , there were 24 alleged self-defenders of 199 individual homicide defendants (12 per cent) ${ }^{65}$ On this last roll, only 2 more defendants (26) were convicted of felonious homicide than were found to have slain according to the strict rules of self-defense.

Although the frequency of elaborate tales of self-defense alone justifies the conclusion that fourteenth-century juries fabricated evidence on the defendant's behalf, it is extremely difficult to demonstrate that they did so in particular cases. The only feasible approach is to compare the coroner's indictment with the trial enrollment in cases ending in verdicts of self-defense. Unfortunately, many coroners' rolls have not survived, and many of those that do exist, like the rolls of the justices of the peace, set forth indictments in curt and highly formulistic phrases that reveal practically nothing about the facts of the case. ${ }^{\circ 6}$ The process of matching coroner and trial enrollments has, nevertheless, produced some striking results that I have reported elsewhere: in a number of cases in which the coroner reported sudden arguments that led to violence, or attacks that could have been avoided without deadly force, the jury set forth a verdict that met the strict rules of self-defense. ${ }^{67}$ None of the cases evidenc-

62. JUST 3/137A.

63. JUST $3 / 149$, mm.1-14.

64. JUST $3 / 142$.

65. JUst $3 / 167$.

66. Many coroners used the term "felonice interfecit" ("slew feloniously") in virtually every case, since the inclusion in the indictment of the inquest jurors' finding of self-defense had no legal significance.

67. See Green, supra note 3, at 676-83. An example of what appears to be conversion of the facts of a felonious homicide may be summarized as follows: According to a coroner's inquest jury, William de Walynford, "brewere," quarreled with Simon de Parys and the latter followed William home, threatening him as they went. The coroner recorded that William forbade Simon to insult him in his master's house and then immediately William fetched a knife and plunged it into Simon's chest. Calendar of Coroners Rolls of THE CTTY of London, A.D. 1300-1378, Roll C, 13, at 80 (R. Sharpe trans. \& ed. 1913) [hereinafter LoNDON CoRONERS' RoLLs]. In the petty jury's account, however, the facts were somewhat different: Simon had attacked William with a knife as they stood in the king's highway. William fled to 
ing transformation of the facts involved a defendant who had been described at the coroner's inquest as having slain through stealth or on account of a long-held grudge. The available evidence from cases ending in self-defense verdicts, then, suggests that the frequent recourse to such findings resulted mainly from the jury's desire to save the lives of defendants who had committed simple homicide.

In addition to this evidence, there is other support for the proposition that the jury's behavior was related to the nature of the defendant's act. First, it is worth noting that, in the fourteenth century, there were even more acquittals in homicide cases than there were verdicts of excusable homicide, so that the proportion of convictions on charges of homicide was generally relatively low, from ten to twenty per cent. ${ }^{88}$ For a variety of reasons, it is not possible to determine whether juries systematically acquitted defendants in cases of simple homicide in the period before $1390 .^{69}$ But there is very clear evidence of such jury behavior during the several decades immediately following 1390 . In that year, a century of protests against indiscriminate grants of pardons of grace culminated in a statute restricting the king's pardoning power when the accused had committed "murder," that is, (roughly) homicide perpetrated

his master's house, where, being cornered by his assailant, he slew Simon as a last resort. JusT $3 / 43 / 1, \mathrm{~m} .21 / 1$ (1325).

It is not possible to determine precisely where society drew the line between homicides viewed as excusable self-defense and homicides viewed as nonexcusable but not deserving of capital punishment. The following two cases may be taken to illustrate the social view of self-defense. In both, the coroners' inquest jury characterized the slaying as self-defense, though neither case met the legal standard for excusable homicide. In the first case, the inquest reported: "William put his hand to his knife in order to draw it and strike Robert. Robert, fearing that William wanted to kill him, in self-defense struck William on the head with a hatchet." JUST $2 / 102, \mathrm{~m} .9 / 2$ (1363). The trial record has not been located, but the slayer was pardoned for selfdefense. Calendar of the Patent Rolls, 41 Edw. 3 pt. 1, at 395 (May 6, 1367).

In the second case, the coroner's jury stated: Walter Clerk and Thomas Clerk argued until Thomas, threatening to kill Walter, "suddenly jumped from the cart and took up an iron fork, intending to run at Walter, but Walter immediately grabbed the fork in his own hand and threw it from Thomas lest he do further damage with it; for which Thomas took Walter by the beard; Walter, because of this, drew his knife and in self-defense struck Thomas in the left arm so that he died." Just 2/18, $\mathrm{m} .45 \mathrm{~d} / 5(1356)$. Perhaps the jurors were lenient in this case because the blow that proved fatal was delivered to the victim's arm, rather than to his head, heart, or stomach. Perhaps Thomas committed the ultimate insult when he "took Walter by the beard." In any event, the suspect's deed clearly did not meet the required standard for excusable homicide in self-defense. No trial enrollment has been located in this case.

68. The conviction rates on the four rolls discussed at notes 62-65 supra are as follows: JUST 3/137A, 20 per cent; JUST $3 / 149$, mm. $1-14,6$ per cent; JUST $3 / 142$, 10 per cent; JuST 3/167, 13 per cent. Hannawalt found a conviction rate of 17 per cent for the fourteenth century in Northamptonshire. B. Hannawalt, supra note 1, at 23.

69. See Green, supra note 3, at 674. 
through stealth or planning, at night or by ambush. ${ }^{70}$ While all felonious homicide remained capital, "murder" as a term of art now found its way into some homicide indictments because the validity of a royal pardon of grace might depend upon whether the felony had been murder or simple homicide. Analysis of several trial rolls that include indictments by coroners and justices of the peace who bothered to discriminate between murder and simple homicide reveals that juries rarely convicted those indicted for simple homicide but sent alleged murderers to the gallows about fifty per cent of the time. ${ }^{71}$ The rate of conviction was the same or somewhat higher than the pre1390 rates. $^{72}$ But the correlation between conviction and the seriousness of the act had become visible.

To review the evidence: Both before and after 1390, juries convicted only about twenty per cent of all homicide defendants. After 1390 , it is clear, those convictions occurred mainly in cases of "murder." Before 1390, cases not leading to conviction were dividedroughly sixty to ninety per cent resulting in acquittals and ten to forty per cent in verdicts of self-defense. The scanty evidence available suggests that self-defense verdicts were set forth in many cases of simple and, therefore, felonious (capital) homicide.

Thus, it appears that during the later Middle Ages jury convictions were largely limited to the most culpable homicides. Defendants who had committed simple homicides, loosely corresponding to the modern categories of unpremeditated murder and manslaughter, received acquittals or were found to have killed in the course of excusable self-defense.

One further problem deserves consideration. It is not altogether clear why a particular defendant who had committed simple homicide received one exculpatory verdict rather than another. The result in individual cases was likely determined in part by medieval criminal procedure. ${ }^{73}$ In the thirteenth century, when judicial visitations (eyres) were infrequent, ${ }^{74}$ defendants who claimed they had acted accidentally or in self-defense could obtain a writ ordering a special inquisition into the nature of the homicide. ${ }^{\text {T5 }}$ If

70. See text at notes 161-202 infra.

71. See Green, supra note 3, at 672-73.

72. JUST $3 / 188$ (1399-1415), conviction rate of 23 per cent; JusT $3 / 203$ (14221430 ), conviction rate of 20 per cent; Just 3/205 (1424-1430), conviction rate of 33 per cent. tive.

73. The following discussion, through text at note 77 infra, remains highly tenta-

74. See note 34 supra.

75. See R. HuNNISETT, supra note 22, at 77-78. See generally N. HuRNARD, supra note 4 , at $37-42$. 
the defendant's claim was upheld, he was pardoned or bailed until the next eyre, when he was required to stand trial. ${ }^{78}$ Defendants not making such a showing at a special inquisition remained incarcerated for months or years before being tried at the eyre. Doubtless, this led many who were confident of obtaining an eventual acquittal instead to seek immediate freedom by demonstrating excusable circumstances.

When gaol deliveries subsequently became frequent, the situation changed radically. There was no longer a need to obtain a special inquisition; nearly all defendants awaited the arrival of the royal justices at gaol delivery. Those who had committed an excusable homicide, as well as those guilty of simple homicide, now had more to gain from acquittal than from a special verdict (with remand to gaol to await a pardon). In order to obtain an acquittal, some who could have obtained a pardon probably avoided making an in-court assertion that they had slain in self-defense. This was so since, once the defendant admitted that he had done the act, the jury was hardly in a position to acquit. There was, however, some risk in declining to assert self-defense. Suspects who were unsure of their neighbors' attitudes toward them or their act might have preferred to admit the deed and to assert that there had been extenuating circumstances such as self-defense, rather than pretend to noninvolvement. Moreover, those who truly deserved a pardon-certainly those who had turned themselves in and established their defense at the time of the coroner's inquest-may have felt more secure in sticking to their story. Quite possibly, as well, pardon carried the reward of social respectability while an acquittal based on community generosity involved some measure of stigma. ${ }^{77}$

That juries manipulated the evidence in a large class of cases can hardly have escaped the bench. Although the justices insisted that nothing less than dire necessity justified killing in self-defense, it is possible that they tolerated with some aplomb the juries' leniency in

76. See generally N. HuRNARD, supra note 4 , at $37-42,51$. If the defendant was bailed, he was subsequently retried, and, if the original finding was confirmed, the defendant was pardoned of the king's suit. In theory, it was still possible for the kin of the slain to appeal the defendant. For this reason, even those pardoned after special inquisitions were to appear at the eyre in case an appeal were brought. As a practical matter, pardon was rarely, if ever, followed by an appeal. See note 22 supra.

77. These considerations also seem to rule out an alternative hypothesis: that jurors convicted perpetrators of serious homicide, contrived pardonable circumstances for perpetrators of simple homicide, and acquitted true self-defenders along with the innocent. Some true self-defenders may have been so treated, but the defendant's choice of strategy in court must frequently have frustrated juries inclined to follow this pattern of response. 
the face of the strict rules. Nevertheless, from the point of view of the bench, remand to gaol to await a pardon and the automatic loss of goods probably seemed a small enough price to pay for those who had in fact committed capital felony. This fact, then, may have left the justices loath to undertake any extension of the formal law of selfdefense. Rather, in every case in which self-defense was alleged, they pressed the jury on two questions: Had the defendant acted out of total desperation? Had he acted without malice?

The jury's inclination to shape the facts in the most positive way for many favored defendants appears to have significantly retarded development of the substantive criminal law. Doctrinal development in the common-law system depended heavily upon a flow of cases raising problems for which the law had no seemingly appropriate answer. This flow was choked off early and effectively by the forms and procedures of the criminal law. The absence of special pleading and the inability to raise questions of law by way of appeal from the courts' decisions were detrimental enough. ${ }^{78}$ But jury behavior played an additional and key role: juries' efforts to preclude completely the possibility that the defendant might be hanged led them to adopt a few existing and predictable patterns of response to cover a wide variety of situations. Had trial juries put forward in candid terms the details of homicides, as inquest juries often did before a coroner, the history of the law of homicide might have been very different.

For example, research reveals no settled doctrine during this period regarding slaying in defense of one's kin (as opposed to the established right to defend oneself). Indeed, no discussion of the question by the bench can be found. It is difficult to believe that slaying in such circumstances was in practice capital felony. ${ }^{79}$ If it was lawful, why does the legal process hide that from our view? One theory might have it that, when a slaying had been in defense of kin,

78. See S. MILsom, supra note 29, at 363-65.

79. One late thirteenth-century treatise, in dealing with homicide that was not felonious, refers to a person "who slays a housebreaker, at least if he is defending himself or his household at the time ..."2 FLETA supra note 52, at 61. Compare 1 BRITTON 113 (F.M. Nichols trans. \& ed. 1865):

Or he may say, that although he committed the act, yet he did not do it by felony prepense, but by necessity, in defending himself, or his wife, or his house, or his family, or his land, or his body, from death; or that he killed the man in defense of our peace, or by some mischance, without any thought of felony; in all which cases, if proved, the appellees shall have judgment of acquittal.

Britton is here concerned only with defenses to a private appeal. He does not sug. gest that all these defenses would result in an acquittal if the trial were pursuant to a royal indictment. Certainly, self-defense would not lead to acquittal in such circumstances. Nor, for that matter, is the passage clear evidence for the proposition that one who defended his kin was entitled de cursu to a pardon of the king's suit. 
the defendant, after the formulistic "not guilty," entered a special plea stating the true facts, and the court accepted such a defense when it was corroborated by the jury. The clerk might then have enrolled the details, simply as a matter of form, in a manner consistent with the rules of defense of one's person. But that theory would have the clerks engaging in deliberate, uniform, and pointless falsification of the record. It is more reasonable to suppose that the defendant expressed his case in the strongest and safest possible terms, or that the jury did so on his behalf, and that always the litany of deliberate but excusable homicide was built upon the foundation of saving one's own life. ${ }^{80}$ Defenders of kin (or of any other person, for that matter) were reported as self-defenders. The concealment of the true facts was total, and the courts never had to grapple with the question of defense of another. The formulae of the law had, in the hands of the self-informing jury, indirectly stunted doctrinal growth. ${ }^{81}$

80. See Green, supra note 3 , at $680-82$.

Two cases illustrate this reliance on self-defense. In C 260/105, no. 13 (1393), John Colles Jr. was tried for the death of William Shepherde. According to the enrollment of the coroner's inquest testimony, the defendant, seeing Shepherde strike the defendant's father, John Colles, Sr., "drew his knife and struck Shepherde in the right part of the neck wounding him mortally and thus he slew him feloniously." At the trial, the jury told a different story. Colles Jr., it asserted, had interceded to part Shepherde and his father. Shepherde then turned on Colles Jr., who fled as far as a wall between two houses, where he was forced to slay his attacker in self-defense.

John, son of Robert de Uptone, was tried in 1339 for the death of Simon Chaucer. According to a London coroner's enrollment made in 1336, Simon Chaucer and Robert de Uptone quarreled on the street. Simon struck Robert, wounding him on the upper lip. John, who was present and saw the incident, seized a "dorbarre" with which he beat Simon on the hands, side and head, killing him. LONDON CORONERs' Rolis, supra note 67, Roll F, 4, at 175-76. The petty jury told an elaborate story, which made John eligible for a royal pardon:

A quarrel broke out between Simon and Robert over certain pennies which Simon owed the latter. Simon took up a staff and wanted to strike Robert, but Robert grasped it firmly in his hands ... Simon drew a knife and stabbed Robert in the mouth so that blood flowed. John, sitting in a shop, saw the fight and rising and taking up a dorbarre ran to the fight to pacify the two if he could. When Simon saw John coming he left Robert and went after John with the knife. ... He chased John as far as a wall ... and held him tightly against the wall so that John could not escape, and he wanted to kill John with the knife which he held in his right hand; and John, seeing that his death was imminent and not being able to escape in any direction, nor otherwise able to save his own life without defending himself, struck Simon in the head with the dorbarre which he held in his hands, wherein Simon died . . . .

C 260/50, no. 60 (1339).

81. In 1506 , it was held that a servant might justifiably slay in defense of his master if his master were otherwise unable to escape, Y.B. Mich. 21 Hen. 7, f. 39, pl. 50 (1506), but the first clear reference to defense of kin that $I$ have found dates approximately from the 1530 's. Spelman noted that

Fitzherbert presented an indictment to the effect that one Parker found a man lying between his wife's legs committing adultery and he killed the man, and all the justices held this to be felony, but I [Spelman, the reporter] put [the case] where a man wants to ravish my wife against her will and I kill him, it 
It is also probable that the conclusory character of jury verdicts inhibited the development of more subtle rules on the standards to be met by defendants claiming self-defense. If the judges had had to pass upon a wide variety of fact situations, ranging along a spectrum from murderous attack to genuine last resort, they might have developed a series of doctrinal principles and distinctions. The bench might have developed rules to deal with defendants who had come under attack and feared for their lives, but had acted somewhat too hastily in retaliation; or with those whose temper had gotten the better of them, whose malicious intent was of the moment and less than homicidal, but whose blow had been deadly. Instead, the courts were presented with only two types of homicide defendants: those said to have acted feloniously, with malitia precogitata and without evidence of mitigating circumstances, and those said to have slain in extremis, in self-defense. Both judicial suspicion of the large latter group and the failure of the system to present "close cases" perpetuated the strict division between felonious and nonfelonious homicide. ${ }^{82}$

\section{B. Justifiable Homicide}

The category of justifiable homicide, meriting acquittal rather than pardon and forfeiture, was extended in the fourteenth century to include the slayers of felons caught in the act of burglary, arson, or robbery. An examination of this development may suggest why those who acted in defense of property fared better under the evolving law than those who acted solely in defense of their person.

The line between justifiable and excusable homicide had long been unclear and prone to inconsistent judicial treatment. ${ }^{83}$ From early times, execution upon a legal order was justifiable. ${ }^{84}$ Slaying manifest felons ${ }^{85}$ and those formally outlawed, ${ }^{86}$ if they resisted ar-

seems that I am able to do this in defense of my wife, as in the case where he wants to kill her.

Spelman's Reports, British Library, Hargrave ms. 388, f. 188a (translated from the original Law French).

82. The speculative nature of this section should be obvious. The direct evidence on judicial behavior that would provide the most satisfactory support for these conclusions is simply unavailable. My argument concerning jury behavior and judicial response is developed more fully at notes 152-59 infra. The problem is discussed in the light of general developments in the law of nonfelonious homicide and the role that automatic forfeiture came to play in the fourteenth century.

83. See N. HURNARD, supra note 4 , at 88-92.

84. See 2 H. Bracton, supra note 43 , at 340 (f. $120 \mathrm{~b}$ ).

85. These included "hand-having" thieves, notorious malefactors, and slayers attempting to escape from the "hue and cry" raised against them. For slayers of handhaving thieves, see, e.g., A CALENDAR OF THE LANCASHIRE Assize Rolls 87 (J. Parker trans. \& ed. 1904); Pleas of Gloucester, supra note 24, pl. 89; Three EARIY ASSIZE ROLIS FOR THE COUNTY OF NORTHUMBERIAND 78-79, 80, 84 (W. 
rest, also came to be justified. Initially, this may have represented an attempt to harness the ancient custom of private retaliation, perhaps because it could not be entirely prevented, by legitimating it solely where the wrongdoer refused to submit to the judicial process. ${ }^{87}$ As the judicial system and the test for refusal to submit to it developed, ${ }^{88}$ these slayings came to be seen as on behalf of the law (pro lege). While for a time some tension between the private deed and that pro

Page ed. 1891) [hereinafter NorTHUMBERLAND ASSIZE Rolis]; YEAR Books of THE REIGN OF EDWARD THE FrRST, 30-31 Edw. 1, at 512 (1302) (A.J. Horwood trans. \& ed. 1863). For slayers of notorious malefactors, see e.g., Just 1/734, m.22d/9 (1256); JUST $1 / 60, \mathrm{~m} .23 / 5$ (1272) (keeper of the peace in Buckinghamshire slew a reputed malefactor who refused to give assurance that he would not harm the countryside and who sought, with drawn sword, to avoid arrest); KB 27/297, m.26d/1 (1334); C 260/55, no. 58 (1343); C 145/21/36 (undated); Plea Rolls of the Reign of Hen. III, in 4 COLLECTIONS FOR A HISTORY OF STAFFORDSHIRE 214-15 (G. Wrottesley trans. \& ed. 1883); Wigmore, Responsibility for Tortious Acts: Its History, 7 HARV. L. REv. 315, 323 (1894). For slayers of would-be escapers from the hue and cry, see, e.g., Just 1/56, m. 44d/1 (1249); NoRTHumberLand Asstze RoLLs, supra, at 80,84 .

86. 2 H. BRACTON, supra note 43, at 362 (f. 128b) ("An outlaw also forfeits everything connected with the peace, for from the time he is outlawed he bears the wolf's head, so that he may be slain by anyone with impunity, especially if he resists or takes to flight so that his arrest is difficult").

87. As early as the seventh century, slayers of outlaws or of manifest felons who would not surrender to the "peace of the king" were protected by the law against retaliation by the kin of the slain. See Ine 33, in Attenborough, supra note 7, at 47: "He who kills a thief shall be allowed to declare with an oath that he whom he killed was a thief trying to escape, and the kinsmen of the dead man shall swear an oath to carry on no vendetta against him. If, however, he keeps it secret, and it afterwards comes to light, then he shall pay for him." Ine's dooms date from about 694. H. Richardson \& G. SAYLES, supra note 8, at 13. For a later (tenth century) law to the same effect, see 2 Aethelstan 1.2, in Attenborough, supra, at 127 ("If however, he [the thief] tries to defend himself, or if he takes to flight, he shall not be spared"). Cf. Alfred 5 to Alfred 5.3, in id. at 67. Alfred employed the ecclesiastical "sanctuary" laws in his own legislation concerning "house protection," i.e., the protection of a suspect who remained in his home and voluntarily gave himself up to stand trial. See generally C. RIGGS, CRIMINal ASYlUM IN ANGLO-SAXoN LaW 3136 (1963).

88. Riggs describes the procedure that had come to replace the automatic prosecution of the feud as follows:

Furthermore, not only was summary police action called for in cases where "known" thieves took to their heels, but it was also extended to cases where men were accused of theft and remained obstinately in contempt of summons. In such cases the procedure to be followed was as follows. Those accused were to be summoned to appear in the district court. If after three summonings they failed to appear in court they were to be fined [II Aethelstan 20]. If the accused still refused to either pay the fine or appear in court the law stated that

"the chief men who belong to the borough shall ride [to his house] and take all that he owns, and place him under surety" [II Aethelstan 20.1]. In short, if the defendant refused to appear in court to answer the charges brought against him, the chief men of the district were to distrain (seize) his chattels. If the defendant still held out, "all the chief men who belong to the borough shall ride and take all he possess and the king shall receive half and the men who ride to apprehend him the other half, and they shall place him under surety" [II Aethelstan 20.4]. And if, after his lands and chattels had been seized, the defendant remained in contempt of summons, "they shall put him to death, unless he escapes" [II Aethelstan 20.6].

C. RIGGS, supra note 87 , at 41-42. 
lege may have existed, we may suppose that the latter eventually won out.

By the thirteenth century, most localities were no longer allowed to execute captured outlaws and manifest felons without trial; that custom had become, by and large, frontier law. ${ }^{89}$ Indeed, so profound was the impress of royal law that thirteenth- and early fourteenth-century judges sometimes insisted that the slayer of a resisting outlaw or manifest felon show that he had acted as a royal official or pursuant to an official order before he could be acquitted. ${ }^{00}$ Other such slayers required royal pardons, usually for self-defense. ${ }^{.1}$ Here there was confusion. While it appears that it was lawful for anyone to slay an outlaw or manifest felon who resisted arrest, it was not uncommon for nonofficial slayers to be recorded, in addition, as having suffered attack and slain to save their lives. ${ }^{22}$ This, indeed, was the surest defense for one seeking to show that he could not otherwise have taken his victim and may have been an embellishment intended to allay judicial suspicion of nonofficial slayers. Yet the inclusion of details of self-defense, which ought to have strengthened the defendant's claim to an acquittal, may well have been responsible for the inconsistent judicial treatment of nonofficial slayers. ${ }^{03} \mathrm{By}$

89. See, e.g., Northumberland Assize Rolis, supra note 85, at 70. In a case where a felon was slain, but not while in flight, local officials informed the court that it was the custom in Northumberland summarily to dispatch robbers taken with the goods in hand. The late thirteenth-century law book 1 BRuTroN, supra note 79, at $36-37$, probably reflects the older rule rather than contemporary practice: "If any man be found killed, and another be found near him with the knife or other weapon in his hand all bloody, wherewith he killed him, the coroner shall be presently fetched, and in his presence the felon shall, upon the testimony of those who saw the felony done, be judged to death."

90. See, e.g., KB 27/343, m.2/4 (1346) (defendant commissioned by the sheriff of Norfolk was acquitted); JusT $3 / 139, \mathrm{~m} .27 \mathrm{~d} / 1$ (1356) (five men joined two constables in arresting a person who laid waste to goods and chattels of a resident of Norfolk; all were acquitted; the court ruled: "And because it seems to the court that what they did in this case, they did through the law [per legem] and through maintenance of the law, it is considered that the aforesaid seven ought to go quit"); JUST $3 / 135, \mathrm{~m} .16 / 2$ (1343) (defendant and thirty-four others pursued and slew a person who had been indicted for several felonies. The court, after determining that the deceased had been indicted before his death and that the defendant had a commission based on that indictment, acquitted the defendant and his posse); A. FITzHERBERT, supra note 50, Corone, pl. 288 (1330); 22 Assize, supra note 60, pl. 55 (1349).

91. See N. HuRNARD, supra note 4, at 90.

92. See, e.g., Just $1 / 65, \mathrm{~m} .47 / 15$ (1286); Just 3/43/1, m.14d/7 (1325).

93. See N. HURNARD, supra note 4 , at 91 , suggesting that in the thirteenth century, courts may occasionally have seized upon details of self-defense in cases of justifiable homicide and thought, somewhat irrationally, in terms of excusable homicide. Hurnard observes that courts more often acquitted where the alleged felon had been slain while resisting arrest than where he had been slain attempting to commit robbery, and she speculates "that it was all too easy for the courts to assimilate [the latter] cases to slaying in self-defence." Id. 
the middle of the fourteenth century, however, the confusion was resolved. Most slayers of outlaws and manifest felons were acquitted; the courts required neither a pardon nor a theory of self-defense. ${ }^{94}$

The class of manifest felons included the ancient "hand-having thief"-quite literally, a felon caught with the stolen goods. ${ }^{95}$ But it did not include one intercepted in an attempt unlawfully to take goods or commit an assault. In the course of the fourteenth century, however, the courts began to acquit as justifiable slayers some of those who had acted to forestall an attempted felony: those who had slain burglars or robbers. ${ }^{96}$ The mere self-defender, on the other hand, was subjected to the rigor of the law of self-defense for at least another two centuries. ${ }^{97}$ This uneven development requires explanation. Why the one change without the other?

While thirteenth-century records reveal occasional acquittals of defendants who slew those attempting burglary or robbery, ${ }^{98}$ most such cases resulted in the granting of a pardon for actual, or alleged, self-defense. $^{99}$ As with the other early cases, embellishment by the

94. For example, in KB 27/297, 26d/1 (1334), a certain William, son of Ralph. was acquitted for the death of Adam Doughty, whom he had decapitated. According to the jury, Adam was a notorious robber who had feloniousiy burgled the house of Thomas, son of Jordan, in Lancashire. William tried to arrest Adam, but Adam stabbed William and fled. William pursued and slew Adam. The court specifically asked the jurors whether William could have taken Adam in any other way, to which they replied that he could not. There is no indication that the bench questioned the jury with regard to self-defense. In JUST $3 / 135,13 d / 3$ (1344), the defendant, taking part with others responding to the hue and cry, shot a fleeing suspect with an arrow. The court ruled that the defendant had acted as an executor of the peace ("ut executor pacis") and acquitted him. In KB 27/528, Rex xlvi/1 (1393), according to the indictment, the defendant saw a stranger ("extraneus") leading away two horses belonging to others. He raised the hue and pursued the stranger and, in apprehending him, struck him in the neck with a sword so that he fell to the ground. Whereupon the defendant beheaded the thief. The court considered the indictment "insufficient" and acquitted the defendant. For further examples, see Just $3 / 43 / 1, \mathrm{~m} .14 \mathrm{~d} / 7$ (1325); JusT 3/137A, 21/2 (1353); KB 27/519, Rex i/2 (1391).

95. See note 85 supra.

96. See text at notes 101-02 infra. It was not until the sixteenth century that the new policy became embodied in a statute. See 24 Hen. 8, c. 5 (1532); text at notes $242-46$ infra.

97. See text at notes 242-46, 293-94 infra.

98. See, e.g., JUST 1/642, m.16/13 (1256) (NoRTHUMBERLAND AssIzE Rolis, supra note 85, at 94). Pollock and Maitland cite this case as an unusual one and assert that the defendant was fortunate. 2 F. Pollock \& F. Martland, supra note 5, at 478. A late thirteenth-century legal treatise refers to such slayings in somewhat ambiguous terms: "Anyone, however, who slays a thief by night is not held to be a homicide [non teneatur], and he who slays a housebreaker, at least if he is defending himself or his household at the time, slays justly [iuste interfecit], and in the same way he who slays another to save himself from death." 2 FLETA, supra note 52, at 61. Fleta groups such acts with excusable slayings in self-defense, for which a pardon was required.

99. See, e.g., Pleas of Gloucester, supra note 29, pl. 362 (1221); C 145/11/33 
defendant, repeated by jurors under oath, produced a sure result where judicial response to the bare truth was uncertain. The judges accepted the implications for legal theory of this factual grafting. Thirteenth-century treatises dealt with defense of property as an extension of self-defense. ${ }^{100}$

In the fourteenth century, however, the judges formulated a new doctrine giving the victim of housebreaking greater latitude in repulsing his assailant. The proposition was first stated laconically, as if an intonement of the hoary law: "It was presented that a man killed another in his own house se defendendo. It was asked whether the deceased came to rob him: for in such a case a man may kill another though it not be in self-defense."101 Moreover, the court sanctioned outright acquittal in this case, thus bringing the defendant under the ancient rule applicable to slayers of manifest felons. In 1348, Justice Thorpe restated the rule more broadly: "And in many other cases a man may kill another without impeachment, as if thieves come to rob a man, or to burgle his house, he may safely kill them if he cannot take them."102

For a time, however, the courts were not positive about the breadth of the rule. In 1357, Thorpe and his fellow justices were confronted with a defendant who had slain a burglar. The court ruled: "Because . . . what the defendant did he did in saving his own life in circumstances in which anyone ought to be able to do so lawfully, it is considered that he be quit."103 This seems to indicate that, while a pardon was not necessary, the defendant had to show he had acted in self-defense.

The hesitation of the bench to separate such cases from those of excusable homicide was reflected in another case. It seems to have

(1259); C 145/13/21 (1266); C 145/32/20 (1274); C 145/49/49 (1290); JUST $3 / 91, \mathrm{~m} .10 \mathrm{~d} / 10$ (1293).

100. See, e.g., 2 H. Bracton, supra note 43, at 408 (f. 144b):

If anyone slays a night thief, he will do so with impunity only if he could not spare him without danger to himself; if he could it will be otherwise. For the life and death of men are in the hands of the king; (as in the case of a certain man ... to whom the king granted a pardon for a death in such circumstances.) And so where one defends himself against hamsocn, which [the English call] the entering of a house in breach of the peace, and the intruder is slain, he will be free of liability if he who killed could defend himself in no other way.

(Footnotes omitted.) For Bracton, to be "free of liability" does not mean, in these circumstances, to be free of the need for a pardon: "[H]e who kills a thief, either a day thief or a night thief, is not liable, [that is], if he could not otherwise escape danger; if he could he is liable. Nor is he liable who kills by misadventure . . ..." Id. at 438 (f. 155). Bracton seems to equate cases of misadventure, where pardons were required, with cases of slaying a thief to "escape danger."

101. A. FitZHerbert, supra note 50, Corone, pl. 305 (1330).

102. 22 Assize, supra note 60 , pl. 55 (1349). See A. Fitzherbert, supra note 50, at Corone, pl. 261 (1349); 26 Asszze, supra, pl. 23 (1353).

103. JUST $3 / 139, \mathrm{~m} .29 \mathrm{~d} / 4$ (1357). 
been settled doctrine by 1356 that a man might slay someone who had entered upon his property with the intention of setting his house on fire. ${ }^{104}$ Yet ten years later, the justices of gaol delivery of Leicester Castle, Thomas de Ingleby and John Cavendish, showed indecision as to treatment of the defendant in Neel's Case:

Reginald Walshman ... came at night around midnight to the house of John Neel and called to John who lay there asleep in his bed to let him come in; he wanted to slay John in John's house; and John refused him entrance, so that Reginald began to break the doors and windows and he said he would burn the house and John and John's wife and everything within the house unless John permitted him to enter. And he intended to burn the house, and John for fear of his death and the burning and for salvation of his life and family got out of bed and went to the door; and Reginald was there with a rock which he threw at John's head, and John ducked and Reginald stood there with a knife drawn in order to kill John and attacked him wanting to kill him, and John being naked and believing that Reginald intended to burn his house and that Reginald wanted to kill him, in saving his own life, stabbed Reginald with a knife wherein Reginald was slain. And the jury say that John could not otherwise have saved his own life. ${ }^{105}$

Neel was released in surety pending a gaol delivery seven months later, when he was acquitted. The court had evidently first considered requiring Neel to obtain a pardon, and it appears likely that the element of self-defense was crucial to the judgment of acquittal.

Because the natural inclination of the jury was to embellish instances of defense of property with details of defense of one's person, few cases presented the courts with the critical test of pure defense of property. And those cases that did come forward may have been perceived as ordinary homicides with some embellishments concerning defense of home and hearth. The mingling of defense of property with defense of person may have resulted in judicial caution toward allegations of the former, and it may have slowed the expansion of the category of justifiable homicide to include defense of property. Nevertheless, that the court in the end granted an acquittal in Neel's Case suggests that, whether or not self-defense remained a necessary element, this expansion had been accomplished. Moreover, by the last third of the fourteenth century, slayers of nocturnal housebreakers no longer appear among those pardoned for homicide se defendendo, though earlier such cases had been abundant. ${ }^{106}$

104. 26 Assize, supra note 60 , pl. 23 (1353). See R. Brooke, La Graunde ABRDgment, Corone, pl. 100 (1576); A. FitzHERBERT, supra note 50, Corone, pl. 192 (1353).

105. Just $3 / 142, \mathrm{~m} .17 \mathrm{~d} / 1$ (1366).

106. See note 99 supra. 
Thorpe's 1348 ruling had pertained not only to housebreaking, but also to attempted robbery. ${ }^{107}$ This position, or something very close to it, was adopted by the whole court when Thorpe put the following case four years later: "A man was indicted for homicide; it was found that the deceased was a thief who assailed the defendant and pursued him closely so that the defendant slew him . . . [A]ll say that he will go quit." ${ }^{108}$ Here, too, it appears that some element of self-defense remained crucial to the finding of justifiable homicide. The effect of this ruling is more difficult to ascertain from the rolls than is the effect of the ruling concerning the slaying of burglars. Again, the records of acquittals provide very few details about the cases. Moreover, the absence of victims of attempted robbery among those pardoned for self-defense is not helpful here. An attack in the open had always been described as an assault with intent to slay, since this was a necessary allegation in self-defense. Other motives, such as robbery, had rarely been mentioned.

This part of Thorpe's ruling was nevertheless of considerable significance because, at least in theory, it broadened the scope of justifiable homicide to include slaying to prevent felony. The new rule concerning the slayers of housebreakers was perhaps less novel; the wrongdoer had already committed the ancient but nonfelonious breach of the peace known as hamsocn. ${ }^{109}$

The extension of justifiable homicide to include slayers of wouldbe burglars and robbers was very possibly a response to what was thought to be-and may in fact have been-an unprecedented contemporary rise in professional crime. ${ }^{110}$ Thorpe's ruling was not expanded, however, to include slayers of criminals who assaulted with intent to kill rather than to rob, not even to include slayers of wouldbe "murderers," as those who committed homicide through stealth were coming once again to be known. ${ }^{111}$ The failure to treat the

107. See text at note 102 supra.

108. 26 Assize, supra note 60, pl. 32 (1353).

109. Bracton defines hamsocn as "the entering of a house in breach of the peace." 2 H. Bracton, supra note 43, at 408 (f. 144b). See 2 F. Pollock \& F. Maitland, supra note 5, at 454-58. In two early thirteenth-century cases, Select Pleas of THE Crown, pl. 60, 86 (F. Maitland trans. \& ed. 1888), hamsocn (or hamsoken) was complicated by theft.

110. See note 173 infra.

111. For "murder" as a term of art, see note 19 supra. The person who slew in repelling such a heinous assault was not acquitted, but had to obtain a royal pardon. See, e.g., C 260/120, no. 28 (pardon for self-defense, CaLENDAR OF THE PATENT Rolls, 3 Hen. 4, at 427 (May 22, 1408)); C 260/92, no. 40 (pardon for self-defense, Calendar of THE Patent Rolls, 4 Rich. 2, at 620 (May 1, 1381)). It was not until the 1500's that slayers of would-be murderers were given a statutory right to acquittal. See text at notes $242-46$ infra. 
slaying of a would-be murderer as justifiable homicide is particularly puzzling since, by the end of the fourteenth century, murderous assault was considered especially heinous. This is shown, for example, by the 1390 statute greatly restricting the grant of pardons "of grace" to perpetrators of stealthy homicide. ${ }^{112}$

The courts may have drawn this line between professional robbers and stealthy killers because the former were considered to be a threat to the entire community, while the latter were deemed a threat only to their intended victims. But it seems more likely that the judges were responding to the juries' practice of finding self-defense in many less serious, yet felonious and undesirable homicides. The bench must have realized that many homicides described as se defendendo had in fact been committed in the course of drunken brawls and similar rows. Against these, too, the law had to provide deterrence, and the procedure of pardon and forfeiture, which was a quasisanction, may have seemed an appropriate deterrent. The true selfdefender, however, especially the one who had repulsed a murderous assault, might have deserved better; moroever, in his case even the logic of deterrence mandated acquittal. But how were the judges to identify the true self-defender? Jury testimony and the defendant's own story were so formulistic that discrimination among alleged selfdefenders was an impossible task. Evidence as to the exact nature of the victim's alleged assault would have been difficult to obtain, as would have been the truth regarding the defendant's efforts to escape without dealing a mortal blow.

The theory of royal mercy that underlay the granting of pardons may also have had something to do with the retention of pardons in self-defense cases. Although, by the fourteenth century, pardons for self-defense and accidental homicide were granted de cursu, ${ }^{113}$ the vestiges of the earlier idea of special consideration survived at least in the formulae that were inscribed on charters of pardon. ${ }^{114}$ Neverthe-

112. See text at notes $179-80$ infra.

113. See note 52 supra and accompanying text.

114. See, e.g., C 66/230, m.21 ("Moved by mercy, we have pardoned ..." ("Nos pietate moti perdonavinus ...")). The pardon still carried the proviso that the defendant "stand to right" ("ita tamen quod stet recto in curia nostra") should the kin of the slain wish to bring an appeal (literally, "should anyone wish to speak against him"). By the late thirteenth century, if not long before, the kin's right to appeal a pardoned slayer had lapsed. It is unlikely that it remained even in theory, though the form of the pardon was unchanged. See note 22 supra. Nevertheless, it is still barely possible that this ancient claim to private compensation against an excusable slayer accounted in part for the retention of the pardon requirement. One would still have to explain why a pardon was required, rather than acquittal with an obligation to stand to right. The rule of automatic forfeiture suggests that pardoned slayers were disadvantaged for reasons other than the kin's right to appeal. Moreover, the expansion of the class of justifiable homicide was accomplished with- 
less, pardons for excusable homicide were retained as a matter of policy as well as of tradition. For, as we shall now see, while selfdefenders required pardons in virtually every case, those who slew by accident did not. "Mercy" was required, it seems, only where suspicion of wrongdoing remained.

\section{Accidental Homicide}

Throughout the thirteenth century, the prevailing rule in cases of accidental homicide was that the slayer was required to obtain a royal pardon. The pardon issued as a matter of course upon a finding of unintentional homicide (misadventure). Even grossly negligent slayers were included within this class of excusable homicide. ${ }^{115}$ By the late fourteenth century, however, the courts frequently granted an immediate acquittal for accidental homicide, no longer insisting that the slayer forfeit his chattels and secure a royal pardon. Though there is no clear evidence as to when and how the new policy was formulated, its widespread application is clear from the rolls. ${ }^{110}$

The majority of all homicide defendants delivered before the justices were acquitted outright. The clerk in most of these cases recorded on the trial roll only the homicide for which the defendant had been indicted, the date and place of that act, the jury's verdict of "not guilty" ("non est culpabilis"), and the court's judgment of acquittal. The evidence does not permit us even to estimate how many such cases were acquittals on verdicts amounting to misadventure. Occasionally, however, the clerk did record the facts of the case in more detail, and, from this small body of hard evidence, it is possible to discern a new departure in the courts' handling of accidental homicide. Judges now acquitted many defendants who had received a jury verdict of accidental homicide. There is additional support for this conclusion: late fourteenth-century trial rolls contain few pardons for misadventures, ${ }^{117}$ and coroners frequently neglected

out concern for the rights of the deceased kin. It led to acquittal of some who formerly required a pardon for self-defense. As we shall see, judicial policy changed with regard to accidental homicide with the same potential effect on the theoretical right of the kin to bring an appeal. See text at notes 115-51 infra.

115. See generally N. HURNARD, supra note 4, at 99-108.

116. But see Y.B. Hil. 44 Edw. 3, pl. 44 (1371); A. FitzmERBert, supra note 50 , Corone, pl. 94 (1371) (judicial statements that acquittal is appropriate in accidental homicide cases). For a discussion of an unsuccessful attempt during the reign of Edward I (1272-1307) to reform the law in this direction, see N. HuRNARD, supra note 4 , at 279.

117. The four rolls discussed at notes 62-65 supra, dating from the period 13511385 , contain no cases ending in the defendant's remand to prison to await a pardon for accidental homicide. 
to record an indictment where the inquest jury found misadventure, as though they believed that the courts were not concerned with such cases. $^{118}$

The gradual disappearance in the fourteenth century of the pardon requirement for accidental homicide may have been the natural outgrowth of an older distinction between homicides resulting from the slayer's act alone and homicides produced by intervening circumstances over which the slayer had no control. Thirteenth-century courts had already more or less systematically acquitted in some accidental homicide cases - those, for instance, involving carts and ploughs. ${ }^{119}$ From one perspective, acquittal in these cases may be taken as a "rough-and-ready" approach to the problem of negligence. More often than not the victim, rather than the driver, had failed to use care. ${ }^{120}$ In shooting accidents and other cases where the slayer was more likely to have been the negligent party, the pardon requirement was maintained. A second plausible explanation of the early resort to acquittals in driving cases is that, by and large, the slaying could be attributed to a nonhuman agent. The cart, plough, horses, or oxen, rather than the driver, might be perceived as the responsible agent. There is an evident confusion between an embryonic concept of fault and the ancient theory governing homicide committed by a nonhuman agent, for which payment of a "deodand" was required. ${ }^{121}$ The courts' stress on the driver's absence of intent, rather than upon his lack of negligence, is therefore revealing. Frequently, when a court had determined that the driver had not "intended" to strike the victim, it concluded that his horse or cart was to blame. The horse might as well have been riderless or the cart empty, for the courts treated such a case as no different from that of a death caused by a tree that had been blown down in a windstorm. ${ }^{122}$

Most of the late fourteenth-century accidental homicide cases in which the defendant was acquitted involved situations where it was perceived that either the slain person himself or an intervening object had been the real cause of death. In this sense, these cases represented

118. See note 149 infra.

119. See N. HuRNARD, supra note 4, at 101-04.

120. Id. at 102.

121. The deodand (literally, "to be given to God," but in fact given to the Crown) represented the value of the agent that caused the death. See R. HuNNISETT, supra note 22, at 32-34; 2 F. Pollock \& F. MAITLAND, supra note 5, at 473-74.

122. See, e.g., 3 Rolis of THE Justices In EYRe AT BedFord, 1227, at 2, 153 (G. Fowler trans. \& ed. 1916) (carts) [hereinafter BEDFoRd EYRE]; JUST 1/280, m.18d (1286) (cart); LONDON CORONERs' Rolls, supra note 67, A, at 30 (1301) (horse ran over deceased "against [the rider's] will"). 
a logical extension of the earlier pattern of acquittals for accidental homicide.

Archery accidents were among the most common causes of unintentional slaying throughout the Middle Ages. ${ }^{123}$ Target shooting, a favorite sport, continued to take its toll despite attempts to require strict safeguards. ${ }^{124}$ Arrows went off course in several recorded instances, for example, one after striking a tree branch ${ }^{125}$ and another after glancing off the ground. ${ }^{12 B}$ The defendant in each of these cases was acquitted, though, in the second, only after the court took the matter under advisement. ${ }^{127}$ Of the shooting-accident cases, these two are the closest in nature to the thirteenth-century acquittals. The defendant had set in motion the agent of death, but circumstances perceived to be beyond his control had determined the outcome; on the other hand, in no way could it be said that the deceased had been responsible for his demise. ${ }^{128}$

Cases in which the deceased was said to have been at fault were not uncommon, ${ }^{129}$ however, and in the late fourteenth century they began to play a significant role. A few shooting cases suggest that the deceased's behavior-contributory negligence, as it were-had become a matter of great concern. Indeed, it is in the context of the victim's action in these cases that the term negligence first gained prominence on the medieval criminal trial rolls. Only on the rarest occasion was that term associated with the slayer; his negligence was almost never at issue. ${ }^{130}$ To the modern mind, it might seem strange

123. T. Green, supra note 50, at 77-82.

124. Jurors at a coroner's inquest, JUsT $2 / 207, \mathrm{~m} .2 \mathrm{~d} / 1$ (1397), described an accident resulting from the slain man's negligence in the course of an event subject to specific regulations at a well-marked area: "[I]t happened that . . . William Swayn negligently [necligenter] and in a disorderly way stood beyond the marker within the limits and bounds set up for the shooting match so that while William Swayn stood negligently in the said manner, William Stonehale shot him with one of his arrows." Compare JusT $2 / 59, \mathrm{~m} .18 / 3$ (1387), where the defendant had yelled a warning to someone who was crossing the shooting area.

125. Just $3 / 167, \mathrm{~m} .72 / 1$ (1384).

126. JUST $3 / 177, \mathrm{~m} .47 \mathrm{~d} / 2$ (1391).

127. In this case, the court also ordered forfeiture of chattels. JUST $3 / 177$, $\mathrm{m} .47 \mathrm{~d} / 2$ (1391).

128. For an early example of acquittal in a shooting case, see JUST $1 / 1060$, m.13d (1279), and the discussion in N. HURNARD, supra note 8, at 279.

129. See text at note 120 supra.

130. In a 1416 case, JUST $2 / 170, \mathrm{~m} .1 / 2$, a coroner recorded the following: "Geoffrey Angulluskey drove a cart ... . [and] through his negligence and inebriation the nearside wheel of the cart ran across the head of Julia who lay at the foot of the wall of her mother, Lucy, without any unusual motion of the cart or horses ... [T] he value of the wheel is twelve pence; the said wheel killed Julia . . . and Geoffrey fled and he has no goods ...." The coroner assigned the negligence to the driver, the only such case I have found on any of the extant coroners' rolls, but he then treated the death as a misadventure due to other than a human agent. He 
that the law was more lenient toward those who had used lethal weapons in a negligent or even reckless manner ${ }^{131}$ than toward those who had retaliated against murderous assaults. ${ }^{132}$ But the paradox is easily explained. The court looked solely to the slayer's intent. Slaying without malice was not felonious. If it could be shown that the deceased had caused his own death in a manner that the slayer could not have predicted, there was a strong presumption of nonmalicious homicide. It was to that end that the allegations in shooting cases leading to acquittals recited that the deceased had gotten in the way and been slain "by his own fault" ("in defectu suo proprio"), or that the deceased had run into the target area through his own foolishness or negligence. ${ }^{134}$

The allegation that the deceased had been foolish, reckless, or at fault runs through the largest and, for legal theory, the most important class of cases identifiable as resulting in acquittal for misadventure. These are cases in which the defendant had the weapon causing death more or less under his control but the deceased, it was said, ran or fell upon it. What came to be of critical importance were the attendant circumstances. Acquittals were gained easily in homicides caused by accidental contact with sheathed knives in games of football and wrestling. ${ }^{135}$ More problematic were cases on the borblamed the death on the wheel, and assessed its value for purposes of the deodand.
See note 121 supra. Geoffrey's goods were assessed presumably because he fled
rather than remain and give evidence. The coroner was subsequently amerced; an
assize clerk later added: "The coroner is at fault for failing to mention who ought
to respond." Most likely the assize clerk, like the coroner, treated the case as a mis-
adventure due to other than a human agent, and the amercement was for failure to
note who ought to respond for payment of the deodand. It is possible, although I
believe very unlikely, that the clerk, noting the coroner's reference to the driver's
"negligence," believed an indictment was merited and was assessing the coroner for
failure to frame one.

131. See, e.g., C 145/11/30 (1261) (defendant threw knife at a cat but hit and killed his wife instead); C $145 / 85 / 18$ (1320) (defendant threw knife at a wall but hit and killed his wife instead).

132. Maitland remarks: "That a man who kills another in self-defence should require a pardon will seem to us even more monstrous than that pardons should be needed where there has been misadventure, for the 'misadventure' of this age covers many a blameworthy act." 2 F. Pollock \& F. MAITLAND, supra note 5, at 483 . In my view, however, the formal rules of self-defense took account of the fact that jury verdicts of self-defense concealed many blameworthy acts. While this does not account for the leniency toward negligence, it does help explain the relative severity of the self-defense rules.

133. See, e.g., JUST $3 / 180, \mathrm{~m} .24 \mathrm{~d} / 8$ (1393).

134. See, e.g., Just $2 / 207, \mathrm{~m} .2 \mathrm{~d} / 1$ (1397). But see Just $3 / 185, \mathrm{~m} .8 \mathrm{~d} / 3$ (1398), where similar allegations as to the deceased's behavior led to defendant's remand and pardon.

135. See, e.g., JUST 1/1194, m.1/1 (1272) (football); C 145/38/20 (1280) (football); Just 3/167, m.30/1 (1381) (football); BEDFORD EYRE, supra note 122, at 1 (wrestling). Cf. C 144/27/31 (1287) (dancing). 
der between self-defense and accident in which the deceased allegedly launched a deadly attack upon the defendant only to die "through his own fault," unintentionally plunging upon his intended victim's weapon. ${ }^{136}$ In essence, these were cases in which the situation of selfdefense had been transformed into one of accidental homicide.

Accidental death in the course of deadly assault, which appears occasionally on the early trial rolls, ${ }^{137}$ became very common in the late fourteenth century. ${ }^{138}$ By then, of course, a great deal more was at stake and much depended upon the characterization of the defendant's act. According to the policy initiated in the 1340's, the excusable slayer not only was required to obtain a pardon but lost his chattels whether or not he had fled. ${ }^{139}$ By the later fourteenth century, however, if the excusable slaying were accidental, the slayer stood an excellent chance of acquittal and retention of goods. ${ }^{140}$ The court was therefore careful in these cases to determine-or at least to elicit a sworn assertion-that the defendant had drawn the knife or sword solely for the exigency of self-defense and had held it steady as a bar to further assault, and that the deceased had of his own motion plunged onto the defendant's weapon. The defendant, it was sometimes said, had not supplied any motion or force at all. ${ }^{141}$ The tenor and form of the testimony bears a greater resemblance to that produced in the late fourteenth-century shooting accidents ${ }^{142}$ than to that set forth in the thirteenth-century cases of deaths suffered by negligent assailants. ${ }^{143}$

136. Compare JUST 3/176, m.6/2 (1390); JUST 3/181, m.7d/1 (1390); JUsT $3 / 179$, m.6/2 (1391); JUST $3 / 183, \mathrm{~m} .2 / 1$ (1395); JUST $3 / 179$, m. $49 / 1$ (1397); Just $3 / 205$, m.11d/7 (1427) (cases ending in acquittals); with Just $3 / 179, \mathrm{~m} .31$ (1387); JUST 3/179, m.28d/6 (1393); JUST 3/179, m.38d/3 (1394); JUST 3/180, m.46d/3 (1395); Just 3/180, m.14/8 (1397) (defendants ordered to obtain pardons).

137. See, e.g., C 260/2, no. 47 (1280); C 144/31/12 (1292); C 260/20, no. 16 (1309). See also N. HuRNARD, supra note 4, at 95-96."

138. See cases cited in note 136 supra.

139. See note 51 supra and accompanying text.

140. See text at notes $115-18$ supra. But see Just $3 / 177, m .47 d / 2$ (1391), where the defendant was acquitted but forfeited his chattels.

141. See, e.g., JUST $3 / 137 A, \mathrm{~m} .8 / 4$ (1351) (after the deceased had struck the defendant and gravely wounded him, he ran after the defendant, who held a pitchfork between himself and his attacker; the deceased then "stupidly ran upon the pitchfork"); JusT $3 / 176, \mathrm{~m} .6 / 2$ (1390) (the deceased had thrown the defendant into a ditch and had fallen accidentally on the latter's knife; the court asked whether the defendant had, out of any malice, held his knife upward toward the deceased ("ex aliqua malitia sursum potuit cultellum suum versus . ..")); JUsT $3 / 179$, m.6d/2 (1391); JUST $2 / 60, \mathrm{~m} .13 / 2$ (1394) (defendant held a sword between himself and his assailant without moving it); JUST $3 / 179, \mathrm{~m} .3 / 1$ (1389) (the jurors stated that the defendant had not moved his weapon but held it still; he nevertheless had to obtain a pardon for self-defense).

142. See text at notes 133-34 supra.

143. See cases cited in note 137 supra. 
Even with explicit, sworn statements from the jurors, the bench appears to have been cautious with allegations of death resulting from negligent assault. The acquittal rate when the jury brought back a finding of this kind seems to have lagged behind that for misadventures surrounded by other less suspicious circumstances. ${ }^{144}$ Indeed, the fact that very few of these latter cases, such as deaths resulting from target shooting, appear on the rolls suggests that they led automatically to acquittal with relatively little testing of the evidence.

The more frequent enrollment of details in cases where "accidents" stemmed from fights suggests that the courts had some difficulty in determining liability in such cases. Perhaps the judges suspected that jurors had now found a convenient way to obtain acquittals for those who had perpetrated simple homicide: rather than portray them as self-defenders who struck the fatal blow, jurors could go one step further and turn them into "accidental" slayers on whose weapons murderous assailants had, through their own fault, flung their bodies (or into "nonslayers," the deceased having "slain himself"). ${ }^{145}$ Evidence of the bench's suspicion regarding such verdicts

144. Compare cases cited in note 136 supra, with cases cited in note 135 supra. It is interesting to note that Thomas Cauteshangre, one of the coroners who responded to the new judicial policy of acquitting in accidental homicide cases by not framing indictments in many such cases, see note 149 infra, did continue to frame indictments in cases where the deceased was said to have run against a knife held up in self-defense. See, e.g., Just $2 / 155, \mathrm{m.9} / 3$ (1382); Just $2 / 155, \mathrm{~m} .10 / 3$ (1383); JUST $2 / 155$, m.11/5 (1385); JUST $2 / 155$, m.16/1 (1389); JUST $2 / 155$, m.21/3 (1392).

145. For cases in which the formula "the defendant slew himself" ("se ipsum interfecit") appears, see, e.g., JUST 3/179, m.4d/2 (1390); JUST 3/179, m.6/2 (1391). In a Year Book case, Y.B. Mich. 44 Edw. 3, pl. 55 (1371), Justice Knivet stated that, had the defendant slain in self-defense, pardon and forfeiture would have been required; here they were not required because the deceased, in attacking the defendant, had fallen upon the defendant's knife and had thereby killed himself.

A sixteenth-century treatise groups this genre of case with suicide ("felo de se"). W. StaUndFord, PleAs of THE CROWN 20 (1557). At another point, however, Staundford treats such cases as though they turned upon the question whether the defendant had any recourse other than to draw his knife. Id. at 16a. The implication is that such homicides were perceived as accidents for which no blame attached to the defendant, rather than as true suicides. Staundford distinguishes two fourteenth-century cases in an effort to explain why one required pardon and forfeiture while the other did not. Id. A defendant who had held his knife in his hand as he lay on the ground had been acquitted while a defendant who had remained on his feet and had held a pitchfork against his assailant's charge was pardoned. In both cases, the deceased had plunged onto the weapon, but in the latter, Staundford asserts, the defendant had other means of escape. While fourteenth century courts did not in fact adhere consistently to a distinction between defendants lying upon the ground and those on their feet, it is possible that in an attempt to weigh the credibility of the jury's testimony, the bench found the former cases more persuasive than the latter. It is also possible that the former cases more often led to acquittals because they were easier to assimilate to accidental homicides where parties engaged in sporting events had fallen upon one another. 
can be gleaned from the fact that many of those defendants who were not acquitted, but who were instead required to obtain a pardon, were pardoned for self-defense rather than for accident. ${ }^{140}$ Judicial caution in the face of the new formula is understandable, yet at times appears extreme. One court, for example, went so far as to discuss whether a pardon was required for a defendant who allegedly ran from his assailant and was spared when the latter slipped and fell upon his own knife. ${ }^{147}$ Perhaps the cases involving assailants said to have fallen upon their own weapons had multiplied beyond all belief. 148

This convergence of the self-defense and accident formulae came at a moment when the law of misadventure was in flux ${ }^{149}$ and the

146. See, e.g., JUST 3/179, m.3/1 (1389); JUST 3/179, m.28d/6 (1393).

147. JUST $3 / 182, \mathrm{~m} .18 / 6$ (1395). The defendant was eventually acquitted.

148. See, e.g., JUST $3 / 179$, m.27/2 (1388); JUsT $3 / 179$, m.27/3 (1388); Just $3 / 179, \mathrm{~m} .4 \mathrm{~d} / 2(1390)$.

149. The new judicial approach to accidental homicide also caused some coroners to be in doubt as to whether indictment was appropriate in cases of accidental homicide. The nature and extent of the confusion, however, are difficult to trace. When a human agent was involved, the coroner was supposed to record the suspect's name, the value of his goods, and, if he had not taken to flight, in whose custody the suspect had been placed. Unfortunately, the extant coroners' rolls reveal very sloppy recording of the essential details so that it is often difficult to determine whether or not the coroner recorded an indictment. Failure to assess the suspect's goods and to note his present whereabouts does not necessarily mean there was no indictment. Each individual enrollment must be interpreted in the light of the entire roll. Some coroners marginated "felonia" beside their indictments, and omission of "felonia" only in cases of misadventure almost certainly indicates failure to indict. Failure to assess goods only in misadventures indicates that no human agent was being held responsible. On the basis of a thorough study of the extant rolls dating from 1350 to 1422 , it is clear that treatment of misadventures was highly erratic, depending only in part on who was coroner; some coroners followed contradictory policies in identical cases.

In many misadventures where no indictment was recorded, the coroner stressed the element of contributory negligence or attributed the death to the force of the weapon itself. John Cook, coroner for Leicester in the late fourteenth century, recorded that "various men . . . were shooting at targets; among them was a certain W. . . . and J. son of $J$. by misfortune ran between the targets . . . and he received a mortal wound from the violent motion of the arrow [of W.] and not from the malice aforethought or felony of W." JUST $2 / 60, \mathrm{~m} .12 / 4(1400)$. There is no cvidence of an indictment in this case. Similarly, another Leicester coroner, John Folvyll, recorded that the deceased, who had been shooting at targets with several others "ran to the target to extract his arrow [and thus $T$. was slain through his own fault and not through the malice aforethought or felony of R.]." JUST $2 / 61, \mathrm{~m} .6 / 5$ (1412). The bracketed phrase and several marginalia, "infortunium," "non felonia," and "deodandum," were added in a new hand over erasures that perhaps had stipulated, as in fact the law required, a felony had been committed. The margination "infortunium" is without exception an indication that the homicide had been written off as a mere misadventure without human agent. Negligence of the deceased was perhaps the determinative factor in this case. Folvyll's roll shows that, into the reign of Henry $I V$, he had systematically taken indictments whenever there had been a human agent, regardless of the degree of contributory negligence. E.g., JUST 2/61, $\mathrm{m} .3 \mathrm{~d} / 3(1400)$. There is no apparent reason for the sudden change.

Thomas Cauteshangre of Hampshire also stressed the negligence of the slain man 
complaints about professional crime were intense. ${ }^{150}$ The convergence offered an opportunity for carving out a species of justifiable self-defense leading to acquittal: Only those who truly repulsed murderers would fit within the class; less worthy "self-defenders" would continue to move through the pardoning process, suffering forfeiture of goods and chattels. But the new category was based upon a fiction of accidental homicide that itself depended upon a tenuous distinction. It is impossible to determine how well it worked in relieving true self-defenders of the strictures of the law of excusable homicide, or even how long it persisted. The fifteenth-century rolls are too incomplete for us to judge.

It appears that within two centuries of its inception this trend toward acquittals in cases of misadventure was reversed. In the sixteenth and seventeenth centuries, the rolls once again reflect a need for pardons in cases of accidental homicide. It is possible that one of the underlying reasons for judicial insistence upon pardons in misadventure was the invention and widespread distribution of firearms. ${ }^{151}$

and often did not make out indictments in such cases. In one case a wrestler carried a knife that his opponent "through his own stupidity and through accident fell upon ... so that the knife wounded him in the stomach." Just $2 / 155, \mathrm{~m} .15 \mathrm{~d} / 1$ (1389). An even more extreme case on Cauteshangre's roll recorded that the deceased had run between two men who fought with knives and "through his own folly came against the knives and was slain." JUST $2 / 155, \mathrm{~m} .8 \mathrm{~d} / 2$ (1383). (A similar case recorded by another coroner, is JusT $2 / 59, \mathrm{~m} .18 / 3$ (1387).) Here, the homicide flowed from an illegal act, but the slain man had himself been foolish; any felonious intent on the slayer's part had not been directed at the eventual victim. Cauteshangre marginated "infortunium" in both of these cases, whereas in all other homicides he recorded the suspect's name in the margin, an infallible indication of indictment.

Many, perhaps most, coroners never deviated from their clear responsibility to consider all human agents as suspects in homicides. One indicted a man for the death of his wife after she ran upon his knife against his will, ("Ricardus [the husband] invitus,") in an attempt to separate him and another man. Just $2 / 164, \mathrm{~m} .6 / 5$ (1390). While William Hatfield, a coroner in Buckinghamshire, seems not to have indicted the bailiff of Wendover for the accidental slaying of a person who responded to the hue (the bailiff "not seeing him"), JUST 2/12, m.30/2 (1367), a Gloucester coroner noted "felonia" in the accidental homicide of a malicious assailant whom the constable of Westbury had ordered to stand to peace: "W., not wanting to stand to peace, attacked the constable. He wanted to kill $P$. [the constable], and P., wanting to fend off the malice of $W$., accidentally wounded $W$. in the right side, from which wound $W$. died .... [T] [ je jury says that W. was the cause of his own death." Just $2 / 40$, m.1/1 (1387). Similarly, John Atherston of Worcester marginated "fe" (i.e., "felonia") in an accidental homicide resulting from the victim's negligence. Just $2 / 207, \mathrm{~m} .2 \mathrm{~d} / 1$ (1397). Compare Just 2/102, m.11d/2 (1363), m.14d/1 (1360). Another coroner did the same in a case in which the assailant, struggling with his intended victim, fell upon his own knife. JUST $2 / 133, \mathrm{~m} .1 / 1$ (1377). Finally, while some coroners dismissed simple accidents occurring during play where no weapon had been drawn, e.g., Just $2 / 69$, m.7/8 (1367); Just 2/126, m.1d/3 (1383), no clear rule appeared in this area. See, e.g., Just $2 / 85, \mathrm{~m} .10 \mathrm{~d} / 4$ (1396).

150. See note 173 infra and accompanying text.

151. See text at notes 295-304 infra. 
Whether the courts were seeking to deter negligence or to punish suspected malice is impossible to determine, but it appears that they returned to pre-fourteenth-century practice and refused to acquit defendants, whether or not the jury stated that the deceased had "slain himself."

\section{Jury Behavior and the Judicial Response}

This study of the late medieval law of nonfelonious homicide has centered on the effects of jury behavior on the development of the substantive law. I have suggested that jury behavior in cases of simple homicide to some extent stifled legal development. Specifically, I have suggested that, had there been a free flow of fact situations, judicial discussion of "close cases" might have resulted in elaboration of the rules of self-defense and felony, singling out true self-defenders for better treatment (acquittal without forfeiture) and producing a class of felonious but noncapital homicide. But, in the absence of direct evidence, it is difficult to prove that judges were in fact influenced by jury behavior. It is always possible, for instance, that judges were mechanically applying the rules of self-defense and that they would have continued to do so even if juries had acted in accordance with the formal rules of liability for homicide.

While there can be no empirical evidence about how courts would have structured those aspects of the law discussed had juries behaved differently, there are developments in the law of nonfelonious homicide that suggest some legal fluidity and a capacity on the part of the bench-perhaps after consultation with the Crown-to modify the traditional common-law rules. The courts singled out slayers of burglars and thieves as justifiable slayers, thus eliminating for them the requirements of pardon and forfeiture. ${ }^{152}$ And the courts developed the theory by which some accidental slayers were acquitted on the ground that they were not true slayers but merely instruments by which the victims, through negligence, caused their own deaths. ${ }^{153}$

However, in related areas the courts demonstrated considerable reluctance to modify the substantive rules. The slaying of a would-be murderer was not included within the class of justifiable homicide; although acquittals were freely allowed in accidents resulting from target shooting, courts were cautious in acquitting for accidental homicides stemming from fights. The pattern of relative nondevelopment in areas where the courts were faced with facts that might

152. See text at notes 101-09 supra.

153. See text at notes $115-48$ supra. 
suggest the appropriateness of acquittal is as important as the pattern of fluidity and growth. On the one hand, the law remained static just where one might expect it to: where the defendant had been involved in a fight for which he might have been at least in part responsible. On the other hand, the defendant in some of these cases was under unprovoked and deadly attack. He was resisting behavior that the law sought specifically to deter in much the same way as were those who slew robbers and burglars. Yet only the latter were deemed worthy of acquittal. One is driven to ask why merely personal selfdefense, especially in cases of defense against murderous assault, resulted in the application of the full rigor of the law of excusable homicide. It does not seem reasonable to suggest, at least for the fourteenth century, that the answer lies solely in the mechanical nature of judicial application of the law. By then, some self-defenders and some perpetrators of accidental homicide were being acquitted; others were not.

A second possible explanation for the courts' behavior in this regard might have been the Crown's need for additional revenue. As long as true self-defenders required pardons, they suffered forfeiture as well. But, considering their likely numbers, acquittal even of all true self-defenders would have cost the Crown a relatively small sum, and acquittal only of those true self-defenders who had slain wouldbe murderers would have involved a still smaller cost. ${ }^{154}$ If the Crown could afford to acquit many of those who had slain accidentally and most of those who had slain robbers and burglars, it could have afforded to acquit those who had slain murderers.

The most plausible explanation for the retention of the strict rules of self-defense, I submit, was the difficulty, given the pattern of jury verdicts, of identifying true self-defenders. But, if jury findings that the defendant had slain an attempted murderer were suspect, why

154. It is impossible to determine either the number of true self-defenders or the percentage of them who slew would-be murderers. Of the ten to forty per cent of defendants who received verdicts of self-defense, many, perhaps most, had failed to comply with the strict letter of the law. Of those who had complied, many had retreated from an attack launched by a friend or neighbor after a heated argument and probably only a few from a truly murderous assault. In any case, many defendants had no goods; others had goods but disposed of them before trial. Moreover, the Crown could not depend on juries to assess the full value of the defendant's goods in cases of true self-defense.

The Crown did stand to gain from forfeiture as it applied to all cases in which juries rendered verdicts of self-defense. See T. Green, supra note 50, at 189-90. Moreover, since most of those cases were in fact instances of felonious homicide, the rule of forfeiture served important deterrent and punitive purposes. See text at note 158 infra. The true self-defenders were, of course, victimized by this interaction of jury behavior and judicial response (unless juries refused to state that the true selfdefenders had goods). 
were findings that he had slain a burglar or robber not equally open to doubt? Why did the courts treat with caution verdicts to the effect that the defendant had slain accidentally in the course of a fight (i.e., where the defendant had stood motionless and his assailant had hurled himself upon the defendant's knife), while apparently giving credence to verdicts of mischance at target shootings?

The suggestion here is that juries did not-or that judges supposed juries did not-engage in total fabrication of the facts. Rather, juries built upon or modified some core of reality. ${ }^{155}$ To emphasize the defendant's absence of malice, juries were not beyond construing common fights as one-sided attacks. They assigned to the deceased responsibility for commencing the struggle, often alleging that the deceased had harbored a grudge against the defendant or had taken him by surprise. Such descriptions may have been ritualistic assertions extended by the jury in its desire to promote the defendant's case. Similarly, the assertion that the defendant held his knife steady and motionless against his attacker's reckless charge stretches the truth but a little further than the clearly acceptable assertion that the defendant actively fought back by striking one blow as he stood, gravely wounded, with his back to the wall.

But it would have been quite another thing for the jury to invent a shooting match or to place the parties in a field where they labored side by side with sharp-edged tools that might go astray. Converting slaying during a fight into slaying to prevent a burglary may have demanded more distortion than the jury was prepared to countenance. After all, in many cases the true facts would have been known to many individuals not sitting on the jury. Reducing complicated facts to particular forms that did "justice" might not have engendered popular disapproval; complete transformation of the facts appears more likely to produce such a result. Moreover, although we cannot be certain about the nature of medieval trials, it is possible that in many cases the defendant told his story first and that the jury repeated, or built upon, his statement. ${ }^{156}$ While the defendant doubtless sought to put the best possible face upon the basic fact that he had slain in the course of a fight, he may out of prudence have stopped short of attempting to achieve an acquittal through a total invention.

The fact that the bench countenanced some legal change within the area of nonfelonious homicide, and the fact that rational explana-

155. The following argument is tentative, but it is supported by those cases $I$ have found where the description of a homicide on the coroner's roll can be compared with the trial jury's verdict. See text at notes 66-67 \& note 67 supra.

156. See text at notes $76-77$ \& note 77 supra. 
tions are available for areas in which the court was reluctant to mandate change, do not, however, prove the proposition that, other things being equal, the bench would have been willing either to modify the outer limits of nonfelonious self-defense or to create an intermediate category of noncapital felonious homicide. Either of those changes would have meant shifting the line between life and death rather than between acquittal and pardon. It is at least possible that, even had juries behaved differently, the legal definition of capital homicide would have remained unchanged-that, if all perpetrators of felonious homicide had been convicted of that crime, they would all have been hanged.

Moreover, even if it is assumed arguendo that judicial confrontation of close cases might have resulted in elaboration of the law of felonious homicide and self-defense, it must be conceded that such a development could have occurred without a flow of close cases. Judges must have been aware that many homicides resulted from brawls that defendants had freely joined and that juries systematically concealed this aspect of the defendants' behavior. The judges could have redefined felonious homicide to secure justice, to induce different jury behavior, or both. Yet they did not do so. Systematic nullification of the formal rules of felonious homicide continued for perhaps two centuries or more. ${ }^{157}$ Why did the Crown not seek to end such nullification by changing the formal rules? Why, for instance, did the Crown not provide a formal fine for those who slew feloniously, but not murderously, rather than formally threaten such persons with hanging only to have to grant them pardons de cursu?

In one sense, of course, perpetrators of simple homicides who were alleged to be self-defenders were fined. At least after 1343, all of them were supposed to suffer forfeiture even though they received pardons. Indeed, the rule of automatic forfeiture, which penalized the true self-defender as well, may have been a belated response to the juries' handling of simple homicide. ${ }^{158}$ In another sense, some feloni-

157. There is strong evidence of jury manipulation of facts for the period 1250 to 1430 . The rolls for the period 1430 to 1550 are too sparse for analysis; thereafter, it appears that juries infrequently returned verdicts of self-defense. See text at note 288 infra. While there is some reason to believe the new pattern of jury verdicts began before 1550, the exact date of the change cannot be determined.

158. Maitland ascribes the new rule to royal desire for revenue generally:

So far as we can see, the homicide who obtained a pardon on the score of misadventure or self-defence (unless he had fled on account of his deed), did not in Henry III's time incur that forfeiture of his chattels which was inflicted upon him in after days. But very often he had fled, and this, so it seems to us, may have enabled our ever needy kings to establish forfeiture as a general accompaniment of the "pardon of course."

2 F. Pollock \& F. MATrLAND, supra note 5, at 481. I suspect, but cannot prove, that the bench was influenced by the frequent recourse of juries to a verdict of self- 
ous slayers could avoid prosecution by paying a "fine"- the cost of a pardon de gratia, money in normal times, forty-days' service in time of war. Between these two provisions, many felonious slayers suffered a penalty even if they were not prosecuted or were prosecuted but avoided conviction through securing a verdict of self-defense.

In any case, everyday brawling and the inevitable ensuing deaths could not be ended altogether by formal legal rules. From the perspective of the Crown and bench, a moderation of the law might only have made matters worse. The adoption of a lesser sanction for simple homicide might have seemed a condonation of jury attitudes and thereby resulted in their amplification. Or it might have produced more convictions only at the expense of encouraging the already widespread recourse to physicial violence. In short, by adhering at least in theory to the strictest rules of criminal liability - by posing what might have been thought to be the greatest threat to the greatest number-the Crown might well have believed that its approach to homicide represented at least a modest deterrent that also produced an important source of money and military service. ${ }^{169}$

defense. The new rule of forfeiture also affected misadventure, but, as we have seen, judges began to acquit accidental slayers, except where they suspected misadventure verdicts concealed simple homicides.

There is, however, another explanation, which the bench itself gave as early as 1347. A Year Book entry of that year noted that the Statute of Gloucester, 6 Edw. 1 , c. 9 (1278), autiorized a pardon for cases of accident and self-defense but said nothing about saving the defendant his goods. Y.B. Hil. 21 Edw. 3, f. 17, pl. 23 (1347). In fact, the Statute of Gloucester dealt with procedures for the granting of writs of inquest into cases of homicide. See N. HURNARD, supra note 4, at 281; 2 F. PollocK \& F. MAITLAND, supra, at 481 . It therefore provided no occasion for dealing with the matter of forfeiture.

The same Year Book entry reveals an important misconception of the Statute of Marlborough, 52 Hen. 3, c. 26 (1267). That statute decreed that the murdrum fine (tho fine imposed upon a hundred for an unexplained homicide, see note 19 supra) was not to be levied in cases of misadventure. The murdrum fine was abolished altogether in 1340 , perhaps some decades after it had fallen into disuse. The bench in 1347 read the Statute of Marlborough to say that misadventure was no longer to be treated as "murder," in the substantive sense of felonious homicide. Due to this misreading, the judges concluded that pardons de cursu in accident and presumably selfdefense cases were of relatively recent vintage (1257) and that the procedure in such cases had been developed soon after by the Statute of Gloucester (1278). Since neither statute dispensed with the rule of forfeiture, which applied in all cases of felonious homicide, the judges' conclusion that forfeiture applied to all of the "new" excusable homicides is understandable. For a discussion of these erroneous statutory constructions and subsequent commentary upon them, see 2 F. PolLock \& F. MAITIAND, supra, at 481-82.

While the judicial misreadings of earlier statutes are understandable, there remains the question of what occasioned judicial inquiry into the problem of forfeiture in excusable homicide. Maitland's suggestion regarding the need for revenue and $m y$ own related suggestion regarding jury behavior in cases that otherwise would clearly have led to forfeiture must remain tentative. In any case, my analysis of the effect of the rule once it had been propounded does not depend upon my suggestion regarding the motivation of the bench in 1347.

159. Douglas Hay's analysis, D. HAX, AlbIoN's FATAL Tree 40-49 (1975), of the 
III. The Statute of 1390: An Analysis of the

Initiative for Change in the LaW of Felonious Homicide

The ancient distinction between murder and less serious felonious homicides re-emerged in the fourteenth century in the course of a parliamentary attempt to restrain the king's power to grant pardons of grace (de gratia) to the most serious offenders. This distinction, however, which was devised solely to determine eligibility for a pardon of grace, apparently had no permanent effect on the substantive law of homicide. Throughout the entire period, all homicides committed with "malice" (i.e., those that were deliberate but neither justifiable nor excusable) remained capital offenses. Nevertheless, it is necessary to undertake a brief review of the early fourteenthcentury legislation and a detailed examination of the statute of $1390,{ }^{100}$ the most important of the fourteenth-century pardon statutes. I shall establish that the pardon statutes created a distinction between serious and simple felonious homicide and suggest some of the reasons for the failure of these statutes to leave a lasting imprint on the substantive law.

\section{A. The Pardon Statutes}

The 1390 statute was the last of many attempts over nearly a century to stem the tide of royal pardons de gratia that flowed, usually for a price, to nondeserving offenders. ${ }^{161}$ The earliest statutes declared that the king might pardon only those who slew se defendendo or by accident, the traditional grounds for pardons de cursu. These statutes, therefore, appear to have endeavored to prohibit all pardons of grace, declaring that all felonious homicides lay beyond the scope of the royal power to extend mercy. ${ }^{\mathbf{1 6 2}}$ This, in itself, nearly defies explanation: Surely justice required greater latitude than the statutes allowed, and literal application of the wording of these statutes plays havoc with the underlying theory of the king as fount of justice. ${ }^{163}$

retention in the eighteenth century of statutes making minor property crimes capital offenses might have some bearing here. Hay observes that these statutes were infrequently enforced to their fullest. Many offenders were not prosecuted by the propertied persons they had victimized; others were treated leniently by jury or judge; some received pardons. The opportunity to extend mercy, Hay argues, enhanced the position of the ruling elites while it allowed for selective enforcement for deterrent purposes.

The retention of the strict rules of felonious homicide in the medieval period may have played a similar role. It gave the Crown a greater degree of power over life and death and an opportunity to extend mercy through pardons of grace and (undeserved) pardons de cursu.

160. 13 Rich. 2, stat. 2, c. 1 (1390).

161. See J. BELLAMY, supra note 37, at 195; N. HuRNARD, supra note 4, at 32526; Kaye, supra note 5, at 377-91.

162. As early as 1309 , Parliament petitioned the king about the frequent pardon- 
It would be a mistake, I believe, to read the early pardon statutes too literally. They may in fact have been speaking to extreme cases rather than to the large intermediate body of simple homicides, and they may have been assuming a distinction close to the one that the statute of 1390 made explicit. It is worth considering how this may have come about.

As we have seen, the law of self-defense required the defendant to prove that he had acted in extremis. ${ }^{164}$ Indeed, by the middle of the thirteenth century, it was considered felonious for a person able to flee deliberately to strike and cause death even if he had been provoked and was in substantial danger. ${ }^{105}$ Yet the early treatise writers, when they considered felonious homicide, dealt mainly with its core element, malice, in the sense of a deliberate, unprovoked attack. ${ }^{108}$ They rarely considered the case where the deceased had been the assailant, and the defendant, acting without true malice but in unnecessary haste, had chosen retaliation rather than flight. It is even unclear that these writers discussed homicides committed in the course of a brawl freely joined, where one of the blows dealt produced an unforeseen fatal result. Had they been pressed to define the outer limits of excusable homicide, they almost certainly

ing of thieves ("larons") who had been indicted for "larcines, roberies, homicides," and other felonies. Those responsible for the indictments, so the petition alleged, feared to remain in their communities; many refused to indict out of similar fear. The petition did not suggest any specific remedy, but the king replied that in the future he would grant pardons only to those found to have slain through misadventure, self-defense, or insanity. 1 Rotuli Parliamentorum 444b (1309). The Ordinances of 1311 carried out the royal response in more general language: "That no felon nor fugitive be from henceforth protected or defended from any manner of felony, by the King's charter of peace . . . unless in a case where the King can give grace according to his oath, and that by process of law and the custom of the realm. ..." Quoted in N. HuRNard, supra note 4, at 323-24. The Statute of Northampton attempted to limit pardons to self-defense and misadventure, $2 \mathrm{Edw} .3$, c. 2 , (1328), and in 1336 a new statute ordered that the Statute of Northampton be observed, 10 Edw. 3 , c. 2.

163. See note 52 supra. The king sometimes pardoned culpable slayers whose acts either bordered on self-defense or for other reasons were not considered especially heinous. See N. HuRNARd, supra note 4, at 244.

164. See text at notes 56-57 supra.

165. See text at note 57 supra.

166. Bracton seems to consider an unlawful homicide as one committed "in premeditated assault and felony." 2 H. BRACTON, supra note 43 , at 438 (f.155). He describes felonious homicide "as where one in anger or hatred or for the sake of gain, deliberately and in premeditated assault, has killed another wickedly and feloniously and in breach of the king's peace." Id. at 341 (f.121). Bracton does not here consider the provoked slayer who responds merely to save himself without being in extremis. Fleta, written a generation after Bracton, refers to wilful homicide as one in which "a man, with corrupt intention, wickedly and feloniously slays anyone by a deliberate attack, in anger or hatred or for the sake of gain." 2 FLETA, supra note 52 , at 60 . 
would have excluded such acts, ${ }^{107}$ but their writings do not articulate a reason for treating them as capital felonies. ${ }^{168}$ Thus the trend of focusing only on extreme cases had begun.

As concern about professional and secret homicide grew, the chasm between those acts singled out for special condemnation and those meriting pardons de cursu grew wider. The attention of both judges and legislators, like that of the treatise writers, may have been diverted from the intermediate category of simple homicide. Indeed, this might have been a result of the prevailing pattern of jury behavior, which narrowed the courts' focus on homicide to the more extreme cases.

Yet another factor sheds light on the likely intent of the early fourteenth-century pardon statutes: a parliamentary misconception regarding the granting of pardons de cursu. In the thirteenth century, kings personally oversaw the pardoning process. Under this procedure, a few technically undeserving slayers, in the interests of justice, had received pardons for self-defense after trial. ${ }^{169}$ In the early fourteenth century, the pardoning procedure changed: routine royal intercession ceased and the chancellor was empowered to issue pardons de cursu in the king's name. ${ }^{170}$ By virtue of this new procedure, pardons de cursu were issued only in those cases in which there had been a judicial determination that the defendant had met the legal standard for self-defense. Thus, although the king retained the power to grant pardons for self-defense to slayers who had not

167. Bracton describes self-defense as follows: "[I]f avoidable and he could escape without slaying, he will then be guilty of homicide." 2 H. BRACTON, supra note 43 , at 340 (f.120b). Here, Bracton states the strict rule of self-defense, but does not specifically refer to provoked slayings where the slayer might not have acted out of malice. Nor does he refer to such acts in his discussion of intentional homicide. See note 166 supra. In his discussion of self-defense, where the slaying was "unavoidable," Bracton states that the slayer acts "with sorrow of heart," $2 \mathrm{H}$. BRACTON, supra, at 341 (f.121), and "without premeditated hatred," id. at 340 (f.120b). But what of the slayer who acts when it was avoidable, "without premeditated hatred" and "with sorrow of heart"? Compare 2 FLETA, supra note 52, at 60: "[M]f the necessity were avoidable, without slaying, a man is guilty of homicide, whereas, should the necessity be unavoidable, he will not be liable to the penalty of homicide, because he has not slain feloniously, but from fear and instinctively, to save himself when he could not otherwise avoid his own death."

168. Bracton comes closest to explaining the rationale for the harsh rules of the law, but his discussion presumes the possibility of rational decision-making. In discussing the capital liability of one who "thinking to strike a light blow, . . . has struck a heavy one and killed ...." Bracton states, "For everyone ought to observe mean and measure in what he does." 2 H. BRACTON, supra note 43, at 438 (f.155b).

169. These included those whose acts bordered on, but did not fall within the legal category of self-defense, N. HuRNARD, supra note 4, at 239-43, and on occasion even brawlers, id. at 244.

170. See note 52 supra and accompanying text. 
met the formal rules of the law, ${ }^{171}$ this power was seldom if ever exercised; it was the rare case in which a defendant could convince the judges to carry forward his case for personal royal consideration. The drafters of the early pardon statutes, however, may not have fully understood this: ${ }^{172}$ the statutes may have been drafted under the incorrect assumption that such cases might still go forward after trial for royal consideration.

In sum, it would appear that Parliament did not intend totally to deprive the Crown of its traditional power in cases long thought appropriate for royal mercy. By allowing pardons only in cases of accident and self-defense, Parliament probably thought it was leaving intact the royal power not only to pardon de cursu according to the strict rules of the law, but also to pardon de gratia those simple homicides that the king, out of true mercy and by appropriate extension of the legal rules, desired to treat as if meeting the formal requirements.

By the middle of the fourteenth century, in any event, statutory preambles and legislative histories provide a clearer insight into the nature of the protest that Parliament had leveled against the Crown. While the statutes continued to distinguish between pardons de cursu and pardons de gratia, it appears that Parliament, seeking to combat what was perceived as a dangerous rise in professional crime, ${ }^{173}$ was

171. It is, of course, possible that the summary procedure for pardons de cursu reflected a new royal policy according to which the king conceded his power to pardon except in cases of accident or in those cases meeting the strict rules of self-defense. Having so reduced his options, he would have little reason to oversee the issuing of pardons de cursu. But it seems more reasonable to conclude that the king, in forfeiting the opportunity to pardon some offenders after trial, did so only as a by-product of his streamlining of the royal administration of pardons de cursu. $\mathrm{He}$ probably had at the time imagined that more suspects would then come to him before trial for a pardon de gratia in return for money or military service.

172. Year Book recognition of the chancellor's summary powers with regard to pardons de cursu dates from the early fourteenth century, the period of the early pardon statutes, see note 52 supra and accompanying text, but Parliament may have overlooked this innovation.

173. There is no systematic study of the growth of professional crime over the course of the fourteenth century. My argument does not depend on the fact of increasing crime; it does depend on the contemporary belief in an increase in "professional" crime. We owe much of our evidence to parliamentary attention to the problem, see note 174 infra, which may reflect the perception of the higher classes rather than actual conditions. The trial rolls from the later decades of the fourteenth century indicate frequent indictments of groups of offenders, especially in cases of theft, and indictments before justices of the peace also reflect a substantial amount of what seems to have been professional crime. See, e.g., Proceedings, supra note 35, at 21239. Gangs seem to have operated openly and ubiquitously. See H. Hewit, supra note 54, at 173-75; Bellamy, The Coterel Gang: An Anatomy of a Band of Fourteenth-century Criminals, 79 ENG. Hrst. REV. 698 (1964). For discussions of thirteenth-century crime, see R. HIITON, A MEDieval SocieTY 248-61 (1966); Pugh, supra note 39, at 18-19. Professor Barbara Hannawalt of Indiana University is at pres- 
concerned mainly with those pardons de gratia obtained by the worst offenders. Notorious malefactors who committed homicide in the course of theft were frequently cited as the targets of the legislation. ${ }^{174}$ Persons who had acted on a sudden impulse or in the course of a common brawl were almost never mentioned, though they were probably responsible for most homicides. Parliament dealt, in short, with those acts that incurred public outrage and seemed beyond the most generous limits of legitimate mercy.

During the later decades of the fourteenth century, parliamentary concern with the problem of professional homicide steadily increased. Possibly as a result of this concern, the terminology of royal commissions to justices of the peace came more fully to define serious homicide, or "murder," as it once again had come to be called in official documents, ${ }^{175}$ and thus to lend special importance to prosecution in such cases. The commission of 1380 , for instance, which empowered justices of the peace to take indictments in cases of "murder," associated that term with ambushing and malice aforethought, or true planning. ${ }^{176}$ Legislative demands for limitations on

ent undertaking an extensive study of crime in the fourteenth and fifteenth centuries.

174. The petition of 1309 had referred to the "too free pardoning of thieves [larons] who had been indicted" for the crimes Parliament sought to prevent. 1 Rotuli Paritamentorum 444b (1309). The statute of 1336 recited: "Whereas murderers, robbers, and other felons, be greatly encouraged to offend, by reason that Charters of pardon of manslaughters ["homicides"], robbery, felonies, and other trespasses against the peace, have been so lightly granted ..."10 Edw. 3, c. 2. The statute of $1340,14 \mathrm{Edw} .3$, c. 15, repeated earlier restrictions on pardons: "Charters have been granted without number to felons and manslayers ["larons et homicides"], to the evil example and fear of good people and lawful, whereby thieves, felons and offenders ["larons et meffesours"] be comforted to do their robberies and manslaughters ["roberies et homicides"] and the same do from day to day ...." In a petition of 1347 , Parliament referred to malefactors without number who received pardons "to the great destruction of the people." 2 Rotuli Paritamentorum 171a. See 2 Rotuli Parlamentorum 172a (1347). A similar petition of 1353 stated that the king, in response to "suggestions" which were less than truthful, had granted pardons to many notorious felons ("larons") and to common murderers, who were to fight overseas and who returned and plundered the countryside. 2 Rotuli Parliamentorum 253b. Kaye correctly notes that Parliament did not distinguish types of felonious homicide in these statutes and petitions. Kaye, supra note 5, at 378. It is possible that Parliament had in mind all felonious homicides; but it is unlikely that in its attempt to prevent the pardoning of really serious malefactors, Parliament proscribed pardons even to those of generally good reputation who, in a sudden quarrel, struck and slew another person.

175. See note 19 supra. For an excellent discussion of the use of "murder" as a term of art in justice of the peace indictments in the 1380's, see Kaye, supra note 5 , at 383-89.

176. "We have assigned you to inquire . . . into all thefts, notorious or open, and mayhems and slayings of men through ambush or malice aforethought, and murders, and other felonies ...." 3 Rotuli Parlamentorum 84b. "Felonies," I believe, incorporated simple homicides. See note 201 infra. 
royal pardoning power may have prompted the frequent insertion in pardons for "all felonies," from about that date, of clauses excepting "treason, murder, and rape."177 In this context, "murder" was not employed as a catch-all for felonious homicide, but was a term of art. $^{178}$

The statute of 1390 gave these legislative demands their fullest embodiment: Limits were imposed on the king's power to pardon homicides committed through murder, ambush, assault, or malice aforethought. ${ }^{179}$ Pardons for these offenses were made quite expensive. They could be obtained only through a request making clear the nature of the killing, and to be effective had expressly to cover these offenses. A trial was to be held to determine the nature of the slaying when a general pardon for homicide was presented to the court. ${ }^{180}$

The meaning of both the commission of 1380 and the statute of 1390 depend largely on the meaning assigned to the term "malice aforethought"- the "malitia precogitata" of the commission and the "malice prepense" of the statute. If the term was meant to coincide with the general "malitia precogitata" that was then employed in indictments as the threshold degree of mens rea for felony, the term would have swallowed up the statutory "murder, ambush, [and] assault," and the pardoning power would have been restricted in all cases of felonious homicide. If, on the other hand, "malice aforethought" was a new term of art encompassing homicides committed through true planning or premeditation, the statutory restraint on the royal pardoning power would have applied only to the most serious forms of felonious homicide. The former position has recently been taken by J. M. Kaye, who, in the first systematic analysis of the statute of 1390, argues that "malice aforethought" was meant to be equivalent to the general "malitia precogitata." I take the oppo-

177. See, e.g., Calendar of the Patent Rolls, 4 Rich. 2, pt. 2, at 610 (March 20, 1381), 624 (May 7, 1381); 9 Rich. 2, pt. 1, at 71 (Dec. 12, 1385), 79 (Jan. 8, 1386), 94 (Jan. 16, 1386), 128 (Feb. 27, 1386).

178. See, e.g., JUST 3/177, m.7/3 (1393), discussed in note 197 infra.

179. 13 Rich. 2, stat. 2, c. 1 (1390): "[T] hat no charter of pardon from henceforth shall be allowed before any justice for murder, or for the death of a man slain by await, assault, or malice prepensed, treason, or rape of a woman . . ." "[Q]e null chartre de pardon desore soit alowe devant qiconqes Justices pur murdre mort de homme occys par agait assaut ou malice prepense treson ou rape de femme . . .").

180. 13 Rich. 2 , stat. 2 , c. $1(1390)$. The section of the statute imposing heavy fines for pardons for the named offenses was repealed in 1392. See note 205 infra.

181. See Kaye, supra note 5, at 391-95. He argues forcefully against the uncritical assumptions of earlier scholars that the statute associated malice aforethought with murder. See, e.g., 3 J. STEPHEN, supra note 53, at 44-46; Maitland, The Early History of Malice Aforethought (1883), in 1 COLLECTED WORKS 304 (1911); Plucknett, Commentary on the Indictments, in ProceEdiNgs, supra note 35, at cxlviii. 
site view in the following discussion. ${ }^{182}$

Kaye's view that malice prepense (the malitia precogitata of the commission of 1380) referred to all culpable homicides rests ultimately on the following argument: Both before and after the statute of 1390, pardons for excusable homicide stated that the defendant had slain "neither through felony nor through "malitiam precogitatam." " If "malitiam precogitatam" meant true malice aforethought, Kaye argues, its use in this context would be odd, for such a denial would not have sufficed; mere deliberateness was enough to preclude a pardon de cursu, and that was what the defendant had to deny. ${ }^{183}$ While Kaye's argument is forceful, the weight of the evidence, as I shall demonstrate, suggests that by 1390 malitia precogitata had come at least temporarily and in one significant context to have a second meaning-true malice aforethought. ${ }^{184}$

That the statutory term "malice aforethought" modified "murder," i.e., especially serious homicide, or at least that justices and other royal officials thought it did, can be shown in several ways. First, one must consider the parliamentary petition to which the statute was a response. This petition sheds important light on the meaning of the terminology used in the statute to which King, Lords, and Commons finally agreed. ${ }^{185}$ It clearly requested that pardons for "murder," treason, or rape be altogether proscribed ${ }^{188}$ and that the court be required both to check the indictment in every case in which the defendant produced a pardon and to hold void the charter of pardon if the indictment was for one of these felonies. ${ }^{187}$ Moreover,

182. In short, unlike Kaye, I believe that the late fourteenth-century chronicler, Walsingham, quoted in Kaye, supra note 5, at 391 , correctly characterized the purpose of the statute when he stated that it made it impossible (or nearly so) for "secret slayers whom the English call murderers" ("occultus jugulator, quales morderers appellant Anglici") to obtain a pardon. I believe that the statute was aimed not only at "secret slayers" in the narrow sense, but also more generally at those who perpetrated planned homicides. Kaye correctly establishes the importance of the term "murder" in the fourteenth century. Our disagreement concerns the term "malitia precogitata" and the breadth of the 1390 statute.

183. See Kaye, supra note 5, at 392-93.

184. Kaye perhaps presupposes greater consistency in the use of malitia precogitata than one ought to expect. The term might have served both its original function of denoting the threshold degree of mens rea and the more technical purpose of describing one specific and aggravated form of mens rea. There could have been little confusion when the phrase "malitia precogitata" was used alongside other phrases that were clearly associated with serious homicide.

185. See 3 Rotuli Parliamentorum 268 (1389).

186. "[T] $]$ he commons pray that henceforth no charter of pardon for treason, murder or rape of woman be granted to any one, at the instance or request of any person." 3 Rotuli Pardiamentorum 268 (1389).

187. "And [the commons pray] that each justice throughout the whole realm, before whom any charter of pardon is alleged, shall search the indictment rolls; and 
the petition urged that if anyone requested a pardon for homicide ("mort de home") and thereafter the homicide was proved to be a murder ("murdre"), the supplicant (or his patron) should pay a substantial fine. ${ }^{188}$

If "murder," as employed in the petition, included all felonious homicides, then, a fortiori, "mort de home" in the petition referred only to nonfelonious homicide-excusable or justifiable killing. But such a reading is inconsistent with contemporary terminology. Kaye, although the strongest proponent of the theory that the statute that resulted from the petition dealt with all felonious homicides, has demonstrated that "murder" was a term of art for the most serious form of felonious homicide. ${ }^{189}$ Moreover, by 1390 pardons de gratia granted for felonious homicide ("for the death [of a person] slain feloniously, as it is alleged"190) often expressly excepted "murder, treason, and rape."191 The courts treated such pardons as valid in cases where juries returned verdicts of simple homicide. ${ }^{102}$ The petition's request that pardons in cases of "murder, treason or rape" be held void is entirely consistent with the contemporary practice of granting this limited form of pardon.

if it is found in the said indictment that it is murder, treason or rape of woman, let the charter be held null." 3 Rotuli PaRLIAMENTORUM 268 (1389).

188. The penalties ranged from two hundred marks to one thousand pounds, depending upon the status of the person making the request. 3 Rotul PARLIAMENTORUM 268 (1389). The penalized supplicant would normally be a lord who had requested a pardon for one of his retinue; the defendant, who had already suffered conviction, hanging, and forfeiture, could hardly be further penalized.

189. See Kaye, supra note 5, at 383-88. Kaye also argues, correctly I believe, that the third term of the statute, assaut (assault), was a term of art referring to a serious form of homicide, much like ambush, which was associated with murder. Id. at 392.

190. "Pro morte . . . feloniter ut dicitur interfecit."

191. See text at note 177 supra. Comparison of an "act" of Richard II's Privy Council, of unascertained date but very likely from the years just preceding the statute of 1390, with the statute itself reveals a clear distinction between mort de homme and murder. The Privy Council act requested that the king not "grant lightly charters of pardon for death of a person [mort de homme], murder, rape of women, robberies and other felonies [dautres felonies] without good information and testimony of sufficient persons." 1 Proceedings and Ordinances of the Privy CounCIL OF ENGLAND 86 (H. Nicholas ed. 1834). This resolution sought to ensure that those who received pardons of grace would be generally reputable persons who could produce sufficient sureties as guarantors of their future good behavior. For a discus. sion of the surety requirement in cases of pardons for felonious homicide, see $R$. HuNNISETr, supra note 22, at 79-80. The act did not go so far as to request proscription of pardons in even the most serious cases, much less in all cases. The petition to which the statute of 1390 was a response, on the other hand, singled out from this list murder, rape, and treason, and requested proscription in those cases. It did not include "mort de homme"; rather it specified that pardons be disallowed solely in cases of alleged "mort de homme" that turned out, upon judicial inquiry, to be cases of murder.

192. See, e.g., JusT 3/177, m.7/3 (1393), discussed in note 197 infra. 
The petition thus requested total restraint on the pardoning of perpetrators of serious homicide ("murder"), but it made no request for a limitation on pardons in cases of felonious but not serious homicide. This fact alone is nearly determinative of the statute's meaning, for it is nearly unthinkable that the King, always jealous of his prerogatives, would respond to the petition by granting more than was asked and assent to a near-total restraint on his power to pardon perpetrators of both serious and simple homicides. If the petition sought to preclude pardons solely in cases of murder, the statutory restraint was almost certainly limited to cases of murder.

A close reading of the statute itself supports this view. The preamble to the statute recited that the Commons had complained about "outrageous mischiefs and damage done to the realm because treasons, murders and rapes of women are too commonly committed. ...." In the body of the statute, however, "murder" was accompanied by the troublesome "ambush, assault, [or] malice aforethought." Kaye admits that the term "murder" was used in the body of the statute as a term of art for stealthy homicide or planning, but insists that the term "malice aforethought" referred to homicides committed with the threshold degree of mens rea needed for all felonious homicide. ${ }^{103}$ If Kaye is correct, the statute employed the term "murder" in two rather different ways: first, in the preamble, in the general sense of all felonious homicides, and then, in the body of the statute, in its more technical meaning of slaying through secrecy and stealth. It seems likely, however, that the term was used consistently in the statute, and, since there is no doubt about its meaning in the body of the statute, it is probable that the technical meaning was intended in both cases. ${ }^{194}$

Another important source of evidence regarding the meaning of the statute is its application by the royal courts. Unfortunately, the surviving records tell us little about whether the courts enforced it. And, of the handful of existing enrollments that do apply the statute, only a few provide insight into its meaning. The small number of relevant enrollments probably ought not to be accorded great impor-

193. Kaye, supra note 5 , at $383-88$.

194. One clause of the statute has engendered some confusion. The statute provided that "no charter of pardon, of treason, nor of other felony, [should] pass the chancery without warrant of the privy-seal, but in case where the chancellor may grant it of his office, without speaking thereof to the king." 13 Rich. 2, stat. 2, c. 1 (1390). This provision merely required that the proper royal seals be placed on all pardons for felony and did not subject pardons for all felonies to the special restrictions placed on pardons for serious homicides. Stephen misinterpreted this provision. See 3 J. STEPHEN, supra note 53, at 43. 
tance in interpreting the statute; rather, they ought to be taken as one element of evidence among the others presented. ${ }^{105}$

Of the enrolled applications of the statute, a few are not inconsistent with, but do not prove, the proposition that the statutory "malice aforethought" referred not just to those homicides considered "murder" but to all felonious homicides. In three such cases, defendants presenting pardons for felony not mentioning "murder" were subjected to an inquisition to determine whether they had in fact committed homicide "per murdram, insidiam . . . malitiam precogitatam." The jurors in each case responded that the defendant had not done so, but had slain "se defendendo."106 The fate of the defendant said to have slain per feloniam, but not per murdram, remained untested.

On the other hand, several enrollments support the proposition that the statute restricted only the power to pardon for murder. In two cases, the judicial treatment of the statute leaves no doubt that the court equated malitia precogitata with murder. In response to questions put by the bench, the jury in these cases both confirmed the truth of indictments employing the term per feloniam ("they say that the defendant slew in the way for which he was indicted") and stated, in specific terms, that the defendant had not acted "per murdram . . . malitiam precogitatam."107 A third case, tried before

195. I have examined nearly every gaol delivery and relevant King's Bench roll from 1390 to 1430 . Pardons were tested against the statute in only a handful of cases, discussed in notes 196-97 infra. The cases come mainly from three different gaol delivery rolls: three from JUST $3 / 180$; three from JUST $3 / 176$; two from JUST $3 / 177$. The clustering of cases might indicate that certain justices, at certain times, remembered to apply the statute or that certain clerks, at certain times, bothered to enroll applications of the statute.

196. JusT $3 / 180, \mathrm{~m} .31 / 6$ (1390); JUST $3 / 180, \mathrm{~m} .31 / 5$ (1390). In these cases, the court had asked the jury whether the defendants had acted "feloniously or out of malice [aforethought?] or not" ("felonice aut ex malitia precogitata necne"). In a later case, JUST $3 / 180, \mathrm{~m} .35 / 7$ (1393), the court seems to have distinguished mere felony and felony with malice aforethought. The court asked a jury "whether the aforesaid felony was done out of malice [aforethought?] or not" ("si felonia facta fuit ex malitia precogitata necne"). The response, however, is not helpful: "[The defendant] did not slay ... out of malice [aforethought?], but in defending himself" ("non interfecit . . . ex malitia precogitata set se ipsum defendendo").

197. In JUST $3 / 177, \mathrm{~m} .32 \mathrm{~d} / 1$ (1393), the defendant, Richard Baker, came before the justices of gaol delivery at Leicester on an indictment of simple homicide (" $f e$ lonice interfecit") and produced a pardon "for the death of" ("pro morte") Adam Sutton. The justices saw fit to hold an inquest by the jury of the neighborhood, "aocording to the Statute, ... . because the charter [of pardon] does not state whether Richard slew Adam through murder, ambush, assault or malice aforethought . . . or not. . . . The jurors say that Richard did not slay Adam through murder, ambush, assault or malice aforethought, but rather in the way in which he was indicted." The coroner's roll, which the clerk copied onto the trial roll as the indictment, recorded that Baker met Sutton one night coming from a tavern and that they fell into an argument ("variis litibus inter ipsos motis") during which Richard struck Sutton a 
King's Bench in Westminister, also suggests this equation of murder and malitia precogitata. Two defendants had been indicted for murder. When they presented pardons for felonious homicide, the court stated that in accordance with the statute of 1390 it was necessary to empanel a jury to determine whether the slaying had in fact been murder. The trial was put over until the next term so that a jury could be brought to Westminister. In the meantime, however, the defendants obtained new charters stating that the King pardoned them for murder committed through ("per") malice aforethought, and they were immediately released. ${ }^{198}$ Two other enrollments are ambiguous on the point, but appear to support this reading of the statute. ${ }^{189}$

Additional evidence that the statutory term "malice prepense" was associated with the term "murdre" rather than with all felonious homicides is found in a 1403 charge to grand jurors that was worded in a way that separated simple homicides from murders, identifying the former as acts of "chance medley" ("chaude melle"). ${ }^{200}$ This

fatal blow. JuST $2 / 57, \mathrm{~m} .15 / 7$ (1390). There is no reference to self-defense on either the coroner's roll or the gaol delivery roll.

In the second case, Just $3 / 177, \mathrm{~m} .7 / 3$ (1393), the defendant, John, son of William Soupere, came before the justices of gaol delivery at Northampton on an indictment of simple homicide ("felonice interfecit"). John put forth a pardon "for all felonies, . . . murders and rapes excepted." The court, presumably to determine whether the pardon, as drafted, was applicable, thereupon held an inquest into the nature of the homicide in question. The jurors were asked whether John had slain through "murder ... or malice aforethought ... or not ...." and replied that he had not done so, but had slain in the manner recorded in the indictment: simply, "feloniously." Here the entire range of terms of the 1390 statute is used as an equivalent for the charter's term "murder."

198. KB 27/529, Rex iii/1 (1392) (emphasis added). See note 201 infra.

199. See Just 3/176, m.10 (1391); Just 3/176, m.11/2 (1391). Defendants indicted for felonious homicide and bearing pardons "pro morte" were released after jury verdicts. The juries were asked "whether or not [the defendant] murdered . . . either through ambush, assault or malice [aforethought?] slew ... or not . .." ("utrum . . . murdravit ... aut per insideas, insultum seu malitiam precogitatam interfecit . . . necne . . ."). They responded: the defendant "did not murder . . . neither through ambush, assault nor malice [aforethought?] slew him" ("non murdravit . . . nec per insideas, insultum seu malitiam precogitatam ipsum interfecit"). The use of "neither . . . nor" suggests that ambush and malice aforethought modified "murder." In another case, KB 27/520, Rex xix/1 (1391), the statute was tested with similarly ambiguous results.

200. Harleian ms. 773, f.50, in Proceedrngs, supra note 35; at 11: "Also you will inquire about all sorts of homicides both of those who lie in wait through malice aforethought [par malice deuant pourpense] in the peace of homes and other places [and who] murder people and of those who slay men through chance medley [chaude melle] . . ." (translated from the original Law French).

The earliest reference to "chance medley" that I have found dates from 1388: two parties "met and, through chance medley, fought together" ("encountreront et par chance melle ensemble combateront"). SC 8/253, no. 12605 . The two terms "chaude melle" (literally "hot medley") and "chance melle" (literally "chance medley") appear to have been interchangeable. In any event, given the narrow definition 
grand jury charge reiterated the association of murder with ambush "through malice aforethought" ("par malice devant pourpense") and burglary, acts that had been the primary concern of pardon statutes and petitions for almost a century. It seems clear that the terms of this charge track those of the commission of $1380^{201}$ and the pardons that, by 1400 , had been given for a generation for all felonies, "murder, treason, and rape excepted."

Finally, a systematic analysis of all the extant coroners' rolls from 1380 until 1430 reveals that many coroners, or assize clerks who

of murder, the "hot medley" of the 1403 grand jury charge cannot reasonably be restricted to cases where the slaying that resulted from the "medley" was excusable; it appears to refer to all homicides stemming from a chance or sudden encounter. For a discussion of sixteenth-century treatise writers who carried forward this meaning of chance medley, see text at notes 227-35 infra.

201. Putnam states that the charges to grand jurors were not "formulated from above by the central government. [They] must on the contrary have been put into shape by local officials ...., working with the commission and with general collections of 'old' and 'new' statutes or with special compilations." ProceEdings, supra note 35, at Xxxv. She draws attention to the similarity between the charge of 1403 and the commission of 1380 . Id. at 11. It seems likely that the drafter of the charge worked either from that commission or from a copy of the statute of 1390 . See id. at 20-25; Early Treatises on the Practice of Justices of the Peace in the FifTEENTH AND SIXTEENTH CENTURIES 102-04 (B. Putnam ed. 1924) [hereinafter EARLY TREATTSES].

The commission of 1380 referred to "slayings of men through ambush or . . . malice [aforethought?], and murders ...." 3 Rotuli ParLiamentorum 84b. The 1403 charge referred to "homicides ... of those who lie in wait through malice aforethought ... and who murder ...." See note 200 supra. The "malitiam precogitatam" of 1380 was transformed into "through malice aforethought" ("par mallce deuant pourpense") (emphasis added). It was no longer an independent phrase; the charge of 1403 referred to it as a means of committing ambush. The seeming dependence of the 1403 charge on the earlier one makes it doubtful that the usage in the latter was a complete innovation. The "malice aforethought" of the $1380 \mathrm{com}$ mission ought therefore to be read as modifying "insidiam" ("ambush"). The addition in 1403 of "devant" ("before," in the temporal sense) gives emphasis to the element of true premeditation and signals the fact that this use of "malitia precogitata" is different from the older use of the term as the degree of deliberateness and wickedness necessary for felonious mens rea.

Several cases in the 1390's support this reading of "malitia precogitata." In one case, KB 27/529, Rex iii/1 (1392), the defendants, indicted for murder and about to face a jury on the question whether their pardons for "felonious" homicide sufficed, secured new pardons that stated: "feloniously slain and murdered through malice aforethought" ("felonice interfecti et murdrati per malitiam precogitatam") (emphasis added). The use of "malitia precogitata" as a means of committing murder is unambiguous. In KB $27 / 543$, Rex xvii/ 1 (1395), the defendants secured a pardon for death and murder: "of malice aforethought feloniously as it is alleged murdered and slew" ("ex malitia precogitata felonice ut dicitur murdravit et interfecit"). The Chancery warrant, C 81/557, no. 10455 (1396), on which this pardon was based, stated: "for death and murder ... feloniously slain and murdered through malice aforethought" " "pur la mort et murdre . . felonousement occis et murdrez pur malice purpensee"). KB 27/547, Rex xvi/6 (1398), recited an indictment to the effect that "of malice and murder aforethought he lay in hiding" ("ex malitia et murdra precogitata iacuit insidiis"). A 1391 Chancery warrant for a pardon, C 81/529, no. 7615, used the phrase: "of his malice aforethought he lay in wait" ("de sa malice devant pensez gisoit agaitant"). CALENDAR OF THE PATENT ROLIs, 15 Rich. 2, at 496 (Oct. 25, 1391). 
glossed the coroners' rolls at time of trial, employed the term "malitia precogitata" (or a variant) not only in its meaning as the threshold for felonious homicide but, when relevant, in its more technical meaning as integral to murder or as a common incident thereof. ${ }^{202}$

\section{B. The Statute of 1390 and the Jury}

The distinction among felonious homicides drawn by the statute of 1390 appears to have been short-lived. By the middle of the fifteenth century, "murder" was employed in indictments as a catchall term for felonious homicide. Simple homicide was swallowed up within it $^{203}$ and remained so until the very late fifteenth or early sixteenth century. ${ }^{204}$ Moreover, it is doubtful whether the statute of 1390 retained any force at all. There is no evidence of judicial enforcement of the statute after the early years of the fifteenth century. Some degree of royal observance of the statute may have continued for a few decades into the fifteenth century, but it seems unlikely that it lasted much longer: ${ }^{205}$ The demise of "murder" as a

202. See, e.g., Jusr $2 / 146, \mathrm{~m} .5 / 11$ (1394) (where the coroner had recorded "slew feloniously . . . out of premeditated thought" ("felonice interfecit . . . ex cogitato premeditato"), an assize clerk inscribed the abbreviation "murd" for "murder" in the margin); JUST $2 / 165, \mathrm{~m} .1 / 5$ (1391) ("felonice et ex precogitata malitia" was marked "murd" by a later hand); Just 2/59, m.18d/4 (1389) (where there appeared "out of malice [aforethought?] and because of old hatred" (" $e x$ malitia precogitata et causea antiqui odii"), an assize clerk wrote "murd" in the margin); KB 27/531, Rex viii/1 (1394) ("through consideration and malice and felony aforethought ... he slew and murdered" ("per avisamentum et malitiam et feloniam precogitatam ... occidit et murdravit")).

In JUST $2 / 235, \mathrm{~m} .2 \mathrm{~d} / 11$ (1380), the coroner recorded that the defendant "feloniously slew [the deceased] . . . with a sword, out of malice aforethought, as he lay at night in his bed" ("feloniter interfecit ... cum uno gladio ex malitia precogitata noctanter in lecto suo iacentem"). This was a common form of "murder," see Green, supra note 3, at 693, and the critical phrase appears at a point that makes it very unlikely that it was a mere formula for felonious homicide. Cf. id. at 689-91 (discussing a half-dozen pre-1380 cases in which "malitia precogitata" appears contextually to mean true malice aforethought). But see KB 27/543, Rex xii d/4 (1397), where the indictment was for felonious homicide and the defendant had a pardon that covered "ambush, malice aforethought or long thought out, assault, murder" ("insidiis, malitia precogitata.sive a longe tempore imaginata, insultu, murdra"). The Chancery warrant on which the pardon was based recited "ambush, present malice or malice long thought out, assault, murder" ("agait, malice presente on longe temps imagine, assaut, murdre"). C 81/522, no. 6918. This use of "malice presente" is the only one I have found on Chancery warrants for pardons. The otherwise invariable phrase is "malice purpensee". See, e.g., C 81/459, passim (1379); /673, passim (1423). It is impossible to say whether "present malice" meant mere deliberateness or true malice aforethought. The use of the word "presente" seems to make a distinction between "malice aforethought" and "malice long thought out." In this one example, then, "malitia precogitata" appears to have been equated with present malice.

203. Kaye, supra note 5, at 569.

204. See text at notes 220-64 infra.

205. The system of fees for pardons set up by the statute was abolished in 1392. Parliament concluded that the statute had encouraged malicious indictments for the 
term of art probably indicated that the statute had become moribund.

Why did the fourteenth-century initiative have such an inconsequential effect on the substantive law of felonious homicide? The principal reason, I believe, was that Parliament had sought only to limit the pardoning power, not explicitly to refashion the rules of criminal liability. Under the formal rules, all felonious homicide remained capital. The Crown had agreed only to a restraint on its power to abrogate the judicial process. Moreover, the relation between the statute of 1390 and the nature of criminal procedure made it unlikely that the statutory distinction between murder and simple homicide would have a significant impact upon the substantive law. What was required for such a development was a large number of trials wherein the critical issue was whether the defendant had committed a murder or a simple homicide; such problem cases remained rare despite the statute. This is not because cases with the potential to pose this problem did not arise. Rather, it is because the procedures surrounding the granting of pardons filtered out most problem cases before the point at which the courts would have been called upon to distinguish between serious and simple homicide.

Unlike the pardon de cursu, ${ }^{206}$ the pardon de gratia was granted before trial and was proffered by the indicted defendant as a bar to prosecution when he was called forward to plead to charges. The statute of 1390 virtually proscribed the pardoning of murderers and required that the court, when a pardon for simple homicide was presented, empanel a jury to discover whether the slaying had in fact been a murder. ${ }^{207}$ But this did not often occur. Most potential defendants who obtained a pardon of grace did so without first being arrested, and most of these never appeared in court. Certainly, once pardoned, they did not appear voluntarily, and there is no evidence

named offenses "to the intent that no man should be so bold to sue the King our lord for such a charter." 16 Rich. 2, c. 6 (1392). The first part of the statute was left intact, so that pardons for the named offenses were entirely proscribed.

Although there is no systematic study of royal pardons after 1390 , the work that has been done suggests that the king continued to pardon some "murderers." Sec J. BELlAMY, supra note 37, at 195-96; ProceEdings, supra note 35, at 315-16, 319, 338; The Shropshire Peace Roll 1400-1414, at 54, 56, 57, 64 (E. Kimball ed. 1959) [hereinafter SHROPSHIRE PEACE ROLI]. But there is also strong evidence that most alleged murderers did not obtain pardons while most of those indicted for simple homicide did. See Shropshire PeAce Roll, supra, passim. One historian argues that, at least for the period 1422 to 1436 , few pardons issued, and those that did were pardons de cursu. See R. STOREY, THE END of THE House of LANCASTer 210 (1966). It cannot be determined whether those indicted for murder did not obtain pardons specifically because of the statute of 1390 or because of the Crown practice of excepting murder from general pardons.

206. See text at notes 52-55 supra.

207. 13 Rich. 2 , stat. 2 , c. 1 . 
that they were arrested merely for the purpose of having their pardons "tested." Other defendants obtained a pardon de gratia after incarceration but before gaol delivery and so were in custody for a court appearance. But even in these cases the bench rarely bothered to empanel a jury to test the appropriateness of the pardon. Had the court tested every proffered pardon de gratia not expressly for "murder," the line between murder and simple homicide might have received far greater attention. Even then, however, jury control over the production of evidence might have precluded judicial legal development. If the enrollments are a true reflection of this process, the court merely concluded from the jury's use of the vernacular equivalents of the terms murdram, insidiam, and malitiam precogitatam that the defendant had committed murder. ${ }^{208}$ There is no indication that jurors, who might have employed these terms in accordance with their own, perhaps looser, concept of murder, ${ }^{209}$ set forth the facts and left to the bench the job of construing the law of homicide.

What effect, if any, the new and short-lived official recognition of "murder" in the sense of especially heinous homicide had on the behavior of juries is impossible to trace. While juries systematically shielded simple homicide suspects from capital punishment in the post-1390 period, ${ }^{210}$ there is reason to believe that this represented a continuation of a long-standing pattern of behavior. ${ }^{211}$ Thus, while we may assume that juries agreed with the new attempts at restraints upon pardons de gratia for serious homicide, their attitudes, though possibly reinforced by the official policy, were not created by it.

Indeed, it is more likely that the influence worked in the other direction-that jury behavior in part conditioned the form taken by the statute of 1390 . The statute seems to have taken account of social attitudes regarding simple homicides, even if it was not actually framed in response to them. While simple homicides remained felonious, the courts rarely were called upon to give effect to that aspect of the law. The king's refusal of pardons of grace to those who would otherwise have been the beneficiaries of jury leniency not only would have been unnecessary, but would have cost the Crown a substantial sum of money and military aid. ${ }^{212}$ The legislators' focus on serious homicide, on the other hand, complemented jury behavior. The courts' success in prosecuting murderers had been hampered not

208. See, e.g., Just 3/177, m.27/2 (1390); Just 3/186, m.3d/1 (1400).

209. See Green, supra note 3, at 692-93.

210. See id. at 671-74.

211. See id. at 674-83.

212. See text at note 54 supra. 
by jury attitudes, but by the king's misuse of the pardoning power. It could be expected that juries would, after the statute's passage, continue to convict many murderers and that the loss of revenue caused by severely limiting royal pardons for murderers would, therefore, be to some extent compensated by an increase in the number of convictions and the accompanying forfeiture of goods and chattels.

Thus it was, in 1390 as earlier, that Parliament sought to prevent the wholesale pardoning of murderers and not to moderate punishment of those who had committed simple homicide. As a result, while the borderline between murder and simple homicide received some fleeting attention, the statute required no judicial attention to the distinction between felonious and nonfelonious homicide.

As we have seen, the principal substantive development in the law of intentional homicide in the fourteenth century occurred within the category of nonfelonious homicide. The courts adjusted the line between excusable and justifiable homicide, acquitting some defendants who formerly would have required a pardon. Juries continued to describe such defendants as self-defenders, but the inclusion of details concerning burglary, robbery, or arson enabled the courts to invoke the alternative theory of justifiable homicide. In this limited and roundabout way, the policy underlying the statute of 1390 and its precursor legislation-that of deterring serious crime-stimulated change in the substantive criminal law. It was, however, a minor adjustment, one that did not speak to the problem of simple homicide. That problem was left to the conscience of the jury. The result was not entirely satisfactory, for jury findings that continued to place some slayers by simple homicide in the class of self-defenders inevitably tainted the pardon de cursu. Slayers of those who had launched murderous attacks but had neither committed burglary nor attempted highway robbery were not easily distinguished from slayers who acted in the course of a brawl freely joined. The pardon for self-defense served both; in the hands of the self-informing jury, the law spoke precisely to neither.

\section{THE TUdOR Transformation IN THE LAW OF HOMICIDE}

The modern law of homicide originated in early Tudor statutes aimed at deterring professional and planned slayings. The Tudor statutory distinction between murder and manslaughter corresponded to the distinction between serious and simple homicide found in the statute of 1390 and the late fourteenth-century commissions to jus- 
tices of the peace, and perhaps reflected their influence. But there were important differences between the respective statutory schemes. First, as we shall see, the expansion of benefit of clergy in the fifteenth and sixteenth centuries allowed juries to convict without condemning to death defendants who had committed simple homicide. The Tudor statutes excluded recourse to benefit of clergy only in cases of murder and did not affect the post-trial availability of the benefit to slayers by simple homicide. Second, even had juries still been inclined to shelter manslaughterers within the category of excusable self-defense, their tendency to do so may have been considerably lessened by the changing nature of the trial procedure. Juries no longer controlled the flow of evidence; the facts were declared by witnesses whom the justices of the peace, acting as prosecutors, had bound over for appearance at trial. Juries then assessed the credibility of the witnesses, weighed the evidence presented, and rendered a verdict. In practice, of course, the verdict could still fly in the face of the evidence produced at trial. But now the disparity between the facts and the jury's verdict in any given case was more obvious and had the potential for engendering conflict between the jury and the court.

In taking testimony from witnesses, the bench was unavoidably confronted with cases bordering on the line between murder and manslaughter. Because the bench could now instruct and control juries on the law in close and difficult cases, the nature of the new trial procedure resulted in the gradual articulation of the modern law of homicide.

\section{A. The Murder-Manslaughter Distinction}

As we have seen, the statute of 1390 enjoyed only temporary and limited success. ${ }^{213}$ There is little evidence of systematic royal enforcement of the statute in the decades immediately following its passage, and it is doubtful that it was observed at all after 1430. As a result, distinctions among felonious homicides became unnecessary. By the later decades of the fifteenth century, all homicide indictments carried the form ex malitia precogitata insultum fecit percussit et felonice interfecit et murdravit (of malice (aforethought?) [the suspect] made an assault, struck and feloniously slew and murdered the deceased). ${ }^{214}$ Surely not every indictment was based on a

213. See text at notes 203-05 supra.
214. Kaye, supra note 5, at 569-70. See, e.g., Procendngs, supra note 35 , at 237-69. 
grand jury assertion that the suspect had committed "murder" as opposed to simple felonious homicide. The justices of the peace appear to have adopted this standard form in order to cover all the terms in commissions empowering them to indict for felonious homicide. Thus it appears that "murder," as employed in official documents, was no longer a term of art. ${ }^{215}$ Similarly, whatever malitia precogitata now meant, it did not stand in indictments for any greater degree of intention than was required for felonious homicide. The demise of the statute of 1390 and the blurring of terms of art in indictments reinforced one another: The former made the terms of art unnecessary; the latter made further enforcement of the statute impossible unless the king were willing to forgo all pardons de gratia for homicide.

While pardons of grace continued to flow steadily out of Chancery, ${ }^{216}$ they no longer represented the only substantial barrier to successful prosecution and execution for capital felony. During the fifteenth century, it appears, the number of defendants who took advantage of benefit of clergy dramatically increased. The institution of benefit of clergy took its basic form during the late twelfth-century struggle between church and state, more specifically, as a result of the clash between Henry II and Thomas Becket. ${ }^{217}$ The Crown conceded to the Church ultimate power to try and punish ordained clergy, but it ordered that such clergy first be tried in a royal court and, if convicted, that they then be delivered over to the bishop as guilty in the eyes of the secular law. ${ }^{218}$ The Church insisted, nevertheless, upon retrial of the convicted clerk in accordance with canonlaw rules; upon a finding of guilt, the clerk suffered punishment by the Church, usually degradation from orders, temporary imprison-

215. An alternative hypothesis would be that "ex malitia precogitata" and "murdravit" remained terms of art, and that the justices of the peace inserted them into indictments in order to make out the strongest possible case. Kaye, however, concludes that "the word Murder had reverted to the broad general descriptive name for culpable homicide of any kind . . . " Kaye, supra note 5, at 569, and points out that several contemporary legal writers used murder to refer to any felonious homicide, id. at 571. See, e.g., Keble, in R. KeIlway, ReLattones, f. 136a (1602) (case 120); Marowe, De Pace Terre et Ecclesie et Conseruacione eiusdem (1503), in EARLY TREATISES, supra note 201, at 286, 378.

216. See, e.g., Calendar of the Patent Rolls, 37 Hen. 6, at 470 (Dec. 3, 1458), 474 (Feb. 10, 1459); 5 Edw. 4, at 471 (Nov. 13, 1465), 477 (Nov. 16, 1465).

217. See generally G. Dalzell, Benefit of Clergy in America 9-42 (1955); L. Gabel, Benefir of Clergy in England in the Later Middle Ages (1929); 1 F. Pollock \& F. Martland, supra note 5, at 441-57.

218. See, e.g., JUST 3/127D, m.11d (1337) ("And in order that it might be ascertained in what capacity [the prisoner] should be delivered, let the truth of the matter be inquired into by a jury"). 
ment, and penance. ${ }^{219}$ Access to benefit of clergy originally required that letters of ordination be formally presented to the trial court. By the late fifteenth century, however, mere literacy, and even feigned literacy, had come to suffice. By that time, the protection against hanging was extended so that even some of the worst lay offenders could avail themselves of the benefit. ${ }^{220}$

A thorough review of the Tudor legislation regarding eligibility to claim benefit of clergy reveals the re-emergence of a distinction between types of felonious homicide. This distinction, which came to be one between "murder" and "manslaughter," was conceptually similar to that drawn by the statute of 1390 and, ultimately, that which the community had long drawn between capital and noncapital homicide. $^{221}$

In 1488 , the Crown sought to reduce the impact of benefit of clergy by prohibiting a layman from twice having recourse to it for certain offenses: "murder [at this time used as a catch-all term embracing all felonious homicides], rape, robbery, theft and all other mischievous deeds."222 While the 1488 statute drew no explicit distinction between different types of felonious homicide, its distinction between first and second offenders signals an important first step in the gradation of punishment for felony.

The first statute reviving the 1390 distinction between types of homicide was that of $1512,{ }^{223}$ which altogether excluded laymen who were convicted of certain felonies from the benefit of clergy:

[A]ll person or persons hereafter committing murder or felony, in any church, chapel or hallowed place, or of and upon malice prepensed rob or murder any person or persons in the King's high-way, or else

219. See 1 F. Pollock \& F. MAITLAND, supra note 5, at 443-45.

220. See T. PlucknetT, supra note 19, at 440; J. SAMAFA, LAW AND ORDER IN Historical PERSPECTTVE 57-62 (1974); 1 J. STEPHEN, supra note 53, at 463-64.

221. The following discussion counters Kaye's analysis. See Kaye, supra note 5, at 573-87. Kaye doubts that the early Tudor clergy legislation distinguished between types of felonious homicide. Earlier studies had assumed, but not proved, such a distinction. See, e.g., 3 J. STEPHEN, supra note 53, at 44-46. Kaye's criticisms of earlier work are often warranted, but, as I shall demonstrate, his own conclusions are open to question.

222. 4 Hen. 7 , c. 13 (1488). In order that the court might know who had already been once benefited, the offender was to be branded after the first conviction. For "murder," the brand letter was "M"; for other felonies, "T."

223. 4 Hen. 8, c. 2. But see the statute of 1496 , by which Henry VII withdrew benefit of clergy from petty treason using "murder" in a way reminiscent of the fourteenth-century usage. $12 \mathrm{Hen} .7$, c. 7. The statute referred to "abominable and wilful prepensed murders," and it referred to a specific case: James Grame of London, a yeoman, "wilfully assented and prepensed the murder" of Richard Tracy, a gentleman and Grame's master, who was "murdered and slain." The need for "murdered" as well as "slain" suggests, but does not prove, that the former had some special meaning. The emphasis on willfulness and assent may well be relevant to that special meaning. 
rob or murder any person in his house, the owner or dweller of the house . . . then being therein and put in fear or dread by the same ... be not from henceforth admitted to his or their clergy, (such as been within holy orders only except). ${ }^{224}$

This legislation appears to have been aimed primarily at predatory and truly premeditated attacks upon the person or property of others. It came at a time when such offenses were thought to have reached crisis levels. ${ }^{225}$ The homicides that often flowed from these attacks, chiefly along the highways and in burglarized homes, had apparently come once again to be known as "murders."228

The re-emergence of a distinction between murder and simple homicide, or "manslaughter" as it was now coming to be known, is reflected in early sixteenth-century legal writings. The definitions of various forms of homicide in these writings not only support the view that the Tudor statutes intended such a distinction, but also strongly suggest a link between that distinction and the one created by the late fourteenth-century legislation.

In his Reading on the Peace (De Pace Terre et Ecclesie) (1503), Marowe at one point characterizes "murder" as homicide where the slayer lies in wait. ${ }^{227}$ Marowe then employs the term "chaunce medle" without defining it.228 Given his narrow use of "murder," it

224. 4 Hen. 8 , c. 2 , § 1.

225. The statute began: "Whereas robberies, murders and felonies daily increase more and more, and been committed and done in more heinous, open, and detestable wise, than hath been oft seen in time past. ..." 4 Hen. 8, c. $2, \$ 1$.

226. Kaye argues that "murder" as employed in this statute referred to all felonious homicides. Kaye, supra note 5 , at 572 . He reads the statute this broadly because of its inclusion of the phrase "of and upon malice prepensed." He takes this to stand for the threshold degree of mens rea. Kaye believes that the term had never lost this meaning since its emergence in the late twelfth or early thirteenth century. See text at note 181 supra. He notes that it would be "unthinkable" to construe "malice prepensed" "as implying premeditation" in the context of robbery. Kaye, supra note 5, at 572. Thus, in his opinion, the phrase meant no more than "deliberately" or "wickedly." Nevertheless, the homicides removed from clergy were described circumstantially. See 4 Hen. 8, c. 2, \$ 1 (1512), quoted in text at note 224 supra. The context of the homicide made the act "murderous"; whether true premeditation was a necessary element is unclear. The use of the term in 1512 was similar enough to its use in 1390 to suggest that "malice prepensed" did imply true premeditation.

227. See Marowe, supra note 215, at 378: "But of manslaughter [the justices of the peace] may inquire and this will mean where a man kills another through chance medley he is subject to inquiry before them. The fourth [type of homicide] is murder, and this is where a man through malice aforethought lies in wait and kills any man, this also is subject to inquiry before the justices, etc." See Plucknett, supra note 181, at cxlix. Kaye terms Marowe's definition "too narrow" because it was confined to ambushings. Kaye, supra note 5, at 573. The objection stems from Kaye's view that in 1503 murder meant felonious homicide. Marowe's usage might not have been the only one appropriate to the term "murder," but it was a commonplace definition of the centuries-old term of art "murder." Marowe's terminology seems to have been drawn from the 1403 grand jury charge. See note 200 supra.

228. See Marowe, supra note 215 , at 378. 
seems likely that he meant by "chaunce medle" something broader than accidental homicide and self-defense. At another point in his Reading, however, Marowe uses "murder" in the broad sense of felonious homicide. ${ }^{229}$ Thus, in the decade before the statute of 1512, it appears that, even in a technical dissertation on the law, the term "murder" could be employed both as a term of art for the most serious form of culpable slaying and as a general term signifying all felonious homicide.

The 1510 edition of the well-known anonymous work The Boke of Justyces of Peas, elaborating upon the distinction between murder and manslaughter, further clarifies contemporary usage:

Murder is properly where a man by malice prepensed lies in wait to slay a man and according to that malicious intent and purpose he slays him so that he who is slain makes no defense against him, for if he does it is manslaughter and not murder . . . . And manslaughter is where two men or more meet and by chance medley they fall at affray so that one of them slays the other; [this] is but felony .... ${ }^{230}$

Obviously, the Boke does not equate "murder" with all felonious slaying, for its definition of "murder" explicitly excludes all sudden encounters and even excludes malicious attacks against which the victim had been able to make some defense. "Manslaughter," on the other hand, applies, according to the Boke, to homicides where the victim had been able to make some sort of defense despite the slayer's stealth and to homicides where slayer and victim had fought together on a sudden encounter ("chaunce medley"). ${ }^{231}$ The Boke's definition of "murder" is perhaps narrower than contemporary usage would have warranted, as none of the other texts or statutes include its no-

229. See id. Marowe here describes one type of "murder": "[F]or if a man intends to beat any person and in the course of this battery he kills another person, this is felony notwithstanding that his intent was not to kill him."

230. The Boke of Justyces of Peas $\mathrm{f} .4 \mathrm{a} / \mathrm{b}$ ( $2 \mathrm{~d}$ ed. 1510).

231. Kaye states that, in the Boke, "Murder is inaccurately confined to ambushing cases . . . ." Kaye, supra note 5, at 574. He argues that the author intended to use "murder" for all felonious homicide. Hence Kaye's skewed analysis of the meaning of the Boke's discussion of "manslaughter by chance medley":

Here the Boke is more informative than Marowe at least in that a chance medley is now identified as a sudden encounter, presumably any fight which has broken out without any prior ambushing of one party by another. But there is still an important ambiguity: are we to assume that any killing in the course of such a fight, even though deliberate, would be reckoned Manslaughter, or must we suppose that the mitigation from Murder was limited in some way-for instance to cases in which the killing had been unintended or accidental, or where though deliberate there had been some element of provocation or of self-defense.

Id. at 57475.

If one takes the Boke's definition of "murder" at face value, the entire range of homicides on a sudden encounter are manslaughters, save for excusable homicides committed through accident or true self-defense. This latter class is not mentioned at this point in the Boke; the purpose of this passage is to distinguish ambush from open fighting. 
defense rule. ${ }^{232}$ But it is nevertheless useful as a confirmation of the characteristics of this special category of homicide that most impressed contemporaries of the statute of 1512.

Sir Richard Eliott, a king's serjeant who rose to Justice of Common Pleas in 1513, writing about 1512 and conceivably commenting upon the statute, ${ }^{233}$ put the distinction in the following form: "Note that murder is where a man lies in wait to murder any person, or with malice aforethought ["malice devant pretence"] to murder someone, but if a man by chance medley without malice aforethought kills someone, it is not murder but manslaughter."234 Like Marowe's Reading and the Boke, Eliott's commentary identifies "murder" with malice prepensed and singles out ambush by way of example; like the Boke, it equates chance medley and manslaughter. ${ }^{235}$

All of these early sixteenth-century writers seem to have written about felonious homicide in terms reminiscent of those of the statute of 1390 , the commission to justices of the peace of 1380 , and the grand jury charge of 1403 , the last of which used the phrase "malice devant pretence" in apposition to "murder." It is, of course, possible that they were reflecting the earlier experience without shedding light on the meaning of "murder" as the term was used in the early Tudor statutes, though that would seem unlikely. In any event, the statutes

232. While this rule did not have treatise or statutory authority, it may, nevertheless, have been close to the heart of the ancient theory of murder. Homicide by poison, for example, was especially heinous because the victim was taken off-guard to the extent that he could not defend himself. Ambush might allow for some defense, but it minimized the possibility of a successful one. On the other hand, fighting openly, on equal footing, might not have met with significant social disapprobation, and neighborhood brawling may even have been an informal example of what higher classes termed a "duel." See Green, supra note 3, at 686-93.

233. Kaye suggests Eliott "may ... have given the . . . opinion after and as an interpretation of the Statute of 1512 . . . Kaye, supra note 5, at 575.

234. British Library, Lansdowne ms. 1072, f.43a (attributed to Richard Eliott).

235. Kaye asserts:

Eliott's definition of Murder is clearly preferable to that either of Marowe or the Boke, in that he does not restrict the crime to ambushing but includes generally killing upon malice devant pretence, presumably a variant of malice prepense: i.e., he includes all deliberate killings. ... The category [of manslaughter], however, is as vague as in [Marowe and the Boke], it not being clear whether the fact alone that a killing took place in the course of a chaunce melle would suffice to remove it from the ambit of Murder.

Kaye,. supra note 5, at 575. Kaye perhaps did not recognize the similarity between Eliott's formulation and the language of the grand jury charge of 1403, which refers to "those who lie in wait through malice aforethought." See note 200 supra (emphasis added). Eliott might have taken the 1403 charge and made its elements more explicit. He separated ambush and "malice devant pretence" and associated the latter phrase with "murder." If, for Eliott, "malice devant pretence" was indeed "a variant of malice prepense," both referred to some degree of true premeditation, not to mere voluntas. The use of "devant" (before) makes Kaye's interpretation highly doubtful. See note 201 supra. 
of the next three decades built clearly upon a distinction very close to the one that these writers had framed.

Parliament's attempt to distinguish professional and stealthy homicides from less serious and more open ones reached its peak around 1530. By then, Parliament had excluded murderers from benefit of clergy, but the records do not allow us to determine exactly what test of murder was applied. While it seems likely that the true murderer was still the slayer who ambushed his victim on the highway or assaulted his victim in the victim's home, it is possible that any degree of true premeditation, rather than sudden deliberation, turned a manslaughter into a murder. ${ }^{236}$

A 1530 statute denying persons who had once been protected by sanctuary and abjuration ${ }^{237}$ the right to take advantage of this shelter for a subsequent "petit treason, murder or felony"238 renders the distinction between murder and manslaughter somewhat clearer than did earlier statutory formulations. The statute provided that sanctuary remained available to such persons, first, if they had obtained a royal pardon for the original felony, and, second, if the subsequent act was "petit treason, felony or manslaughter by chance medley, and not murder of malice prepensed . . .."239 A general pardon for all felonies, "murder and treason excepted,"240 was apparently available to those who slew feloniously but not of malice prepensed, that is, through "manslaughter by chance medley." If "manslaughter by chance medley," as employed in the statute of 1530 , meant no more than legitimate self-defense or accident, the exception in that statute would have made little sense: In cases of self-defense or accident,

236. See text at notes 259-61 infra.

237. A felon who had escaped to a church or other designated holy place could remain there inviolate for 40 days. If he confessed his felonies to a coroner within that time, he was allowed to abjure (swear he would leave) the realm. The coroner then assigned the abjuror a port and gave him a cross to carry as a sign of his abjuration. So long as the felon headed straight for the port, no one was permitted to harm him. See R. HunNISETT, supra note 22, at 37-54. See generally N. TrenHOLME, The Right of SANCTUARY In ENGLAND (1903). For the Anglo-Saxon background of medieval sanctuary, see C. RIGGs, supra note 87.

Although sanctuary was not abolished until 1624, 21 James 1, c. $28, \S \S 6,7$, the Tudors set strict limits upon the institution. Abjurors were branded to ensure their identification, 21 Hen. 8, c. 2 (1529), and the statute of 1530-1531 did away with abjuration of the realm, 22 Hen. 8, c. $14, \S 1$. Now the felon in sanctuary was to choose, or be assigned to, one of a number of appointed sanctuaries in England. Thereafter, he could not leave that appointed sanctuary without pardon or special license. See Hunnisett, The Last Sussex Abjurations, in 102 SusseX ARCHAEOLOGICAL Collections 39 (1964); Thomley, The Destruction of Sanctuary, in TUDOR STUDIES PRESENTED to A.F. POLIARD 198-207 (1924).

238. 22 Hen. 8 , c. 14 , $\$ 2$.

239. 22 Hen. 8 , c. $14, \S 4$.

240. 21 Hen. 8 , c. 1 (1529). 
pardons were available de cursu, and sanctuary and abjuration were unnecessary shelters from the law. ${ }^{241}$

The distinction we are tracing is also evident in an important statute of 1532 , which sought to clarify the liability of one who slew a person who had attempted to "rob or murder"242 him on the highway or in his dwelling. The preamble to the act stated that there had been "question and ambiguity" as to whether the slayer "should for the death of the said evil disposed person forfeit or lose his goods and chatteis for the same, as any other person should do that by chance medley should happen to kill or slay any other person in his or their defense ...."243 The act mandated that such a slayer ought not suffer forfeiture, "but shall be thereof, and for the same fully acquitted and discharged, in like manner as the same person or persons should be if he or they were lawfully acquitted of the death of the said evil disposed person or persons." ${ }^{244}$ The statute did not expressly define "murder," which was merely one of several acts that, if attempted by the deceased, permitted his slayer to go free. It is clear, however, that "murder" as employed in the statute did not refer to all felonious slayings. Surely not every act of self-defense, including acts undertaken by one not in extremis, was to lead to acquittal. The statute referred to homicides committed in ways long considered particularly serious: homicides committed by a person who came to rob or slay or the highway, in passageways, or in the victim's home or on his grounds. Rather than single out the element of stealth, the statute appears to have dealt generally with professional or clearly planned acts of homicide. Indeed, some contemporaries thought it applied only to homicidal attacks perpetrated by thieves. ${ }^{245}$ While

\footnotetext{
241. Similarly, section three of the statute excluded from benefit of clergy those persons

found guilty after the laws of this land, for any manner of petit treason, or for any wilful murder of malice prepensed, or for robbing of any churches, chapels, or other holy places, or for robbing of any person or persons in their dwelling houses, or dwelling place, the owner or dwelling in the same house, his vife, his children or servants than being within, and put in fear and dread by the same, or for robbing of any person or persons in or near about the highways .....

23 Hen. 8, c. 1, \$ 3 (1530-1531). Here "murder" was associated with "malice prepensed." While there is nothing internal to the act that conclusively disproves the thesis that "murder" referred to all felonious homicides, the other crimes excluded from clergy suggest that Parliament was concerned with the kinds of acts that earlier had been singled out as most serious. See text at notes 173-79, 199-201 supra.
}

242. 24 Hen. 8, c. 5.

243. 24 Hen. 8, c. 5.

244. 24 Hen. 8, c. 5 .

245. This misinterpretation of the statute may have begun with William Staundford. Writing in 1557, Staundford noted that there had been doubt whether someone who slew a would-be thief ought to suffer forfeiture. He asserted that the statute of 1532 was passed to settle this issue. W. StaundFord, supra note 145, at $14 \mathrm{v}$. He 
the precise meaning of the statutory terminology is unclear, it appears that some circumstantial distinction among culpable attacks-presumably that of the statutes of the years immediately preceding-was being carried forward.

Like the earlier sixteenth-century statutes on murder, the statute of 1532 did not define types of homicide but dealt with eligibility for protection from liability in specific cases. By earlier mandates, the murderer had lost his right to sanctuary and benefit of clergy; now the slayer of a would-be murderer merited acquittal and was immune from forfeiture of chattels. Both the act of 1532 and the earlier Tudor statutes reflect concern with a particular type of homicide. Moreover, the 1532 act effected a logical extension of the rules of liability for justifiable homicide that had begun to expand in the fourteenth century. ${ }^{246}$

distinguished killing a thief from pure self-defense, where a pardon and forfeiture remained appropriate. In the one case, the defendant dealt with a thief, in the other the defendant dealt with a lawful man ("loial home"). Id. Staundford might have considered even a would-be murderer a "loial home," but it is more likely he had in mind the assailant who acted suddenly in the course of a chance medley. Since most perpetrators of murder probably were motivated by financial gain, Staundford might not have focused his attention on the person who attempted solely to commit the most heinous form of homicide.

Coke, writing in the seventeenth centary, also implied that the statute referred mainly to cases involving thieves:

Some Thomicides are justifiable] without any giving back to a wall, etc. or other inevitable cause. As if a thief offers to rob or murder $B$ either abroad or in his house, and thereupon assaults him, and B defends himself without any giving back, and in his defence kills the thief, this is no felony; for a man shall never give way to a thief, etc., neither shall he forfeit anything. And so it is declared by the statute of 24 H.8.

E. CoKe, THE INSTITUTES pt. 3, at 56 (5th ed. 1671). The statute, however, had not referred to "a thief," but rather to "a person" who attempted to rob or murder. Coke's use of "As if a thief" suggests, perhaps, that even for him it was only the most common, not the sole, context in which the statute was applied.

1 M. Hale, Pleas of the Crown 258 (1736), and 1 W. Hawkins, Pleas of THE CROWN 71-72 (1716), perhaps taking Coke too literally, stated that the statute of 1532 affected forfeiture only where the slayèr had killed a would-be thief. See Beale, Retreat from a Murderous Assault, 16 HARv. L. REv. 567, 573-76 (1903).

Other contemporary commentators gave the statute a broader interpretation. See, e.g., Dalton's report of Copstone's Case (1573), in M. Dalton, The Countrey JusTICE 251 (1630):

There was malice between Copstone and one S. and they had fought divers times, and after met suddenly in London Street, and C. told S. that he would fight with him, \& S. answered that he had nothing to say unto him, and S. went to the wall, and after $C$. assaulted S. and then S. struck and killed C. and it was found that $C$. began the affray, and $S$. was thereupon discharged without forfeiting anything: But that was by force of the statute $24 \mathrm{Hen} .8 \mathrm{ca} .5$.

In an unpublished contemporary report of a 1627 case, Harvard Law School ms. 106, f.294v, the statute was said to take effect in cases where the deceased had attempted to "murder, rob, or burglarily to break mansion houses . ..." The placement of "murder" suggests that it did not refer solely to a homicide perpetrated in the course of a robbery.

246. See text at notes 83-114 supra.

Not all slayers of murderers and burglars, we may be certain, acted in pure self- 
The statute of 1532 did not cover those who "by chance medley" slew other than murderers or robbers in self-defense. Presumably, these other slayers continued to require pardons and suffer forfeiture. The act's use of "chance medley" in connection with self-defense is, at first, bewildering. There is little reason to believe that the term always meant homicide in self-defense and nothing more. Its use in statutes and in other texts both before and after 1532 is inconsistent with so narrow a definition. ${ }^{247}$ More likely, it usually referred to any one of many homicides that were not truly premeditated, all of which stemmed from a sudden or chance falling out, some of which were felonious but clergiable, and others of which were excusable as true self-defense. In sum, whatever the precise meaning of "chance medley" in the 1532 statute, that enactment contemplated two different classes of culpable attackers: first, murderers or robbers, whose slayers merited acquittal; and, second, other less culpable assailants, whose slayers either were clergiable or, if they had acted in true selfdefense, merited a pardon. ${ }^{248}$

defense. Some defended their persons, but might in fact have escaped death without retaliating physically; others defended their homes and property. The statute of 1532 appears to have applied to all these slayers. Such slayers, like those who had slain burglars two centuries before, see text at notes 98-100 supra, in presenting to the court their legal defenses, would be likely to offer evidence showing self-defense along with evidence showing defense against robbery, burglary, or ambush, even though the former evidence was not statutorily required. This is largely conjecture. however, as there are few Tudor criminal assize records before the 1550's, and those that do exist do not reveal the defendant's allegations.

247. See text at notes 227-35, 240-41 supra. Fitzherbert at one point equates "chance medley" and felony:

[J]ustices of peace have no authority to inquire of murder as it is in its proper nature, but of manslaughter as a thing feloniously done by chance medley, they may inquire, for murder is not expressed in the commission. But forasmuch as every murder contains felony in itself, therefore if a man be indicted before a justice of the peace for the murder of another, whom he of malice prepensed lying in wait did kill ... and so appears the diversity between murder and manslaughter of which the one comes by malice prepensed and the other but by chance.

A. Fitzherbert, New Boke of Justices of the Peace cxxiiia (1537).

Kaye doubts that Fitzherbert was distinguishing among felonious homicides. He states that Fitzherbert molded "his definition, or example, of Murder on an actual indictment for one type only." Kaye, supra note 5, at 576. Even if that is true, Fitzherbert's "example" makes clear the essential nature of murder. His use of "malice prepensed" suggests that the term meant true premeditation or planning. Kaye, believing that "murder" stood for all felonious homicides, has difficulty disposing of Fitzherbert's identification of "chance medley" with manslaughter and felony. Kaye asserts: "To say that 'manslaughter cometh but by chaunce' is not very helpful." Id.

248. References to murder and chance medley on the King's Bench rolls after the statute support this analysis. In R. v. Fowler, KB 27/1102, Rex m.7 (1537) (indictment at KB 9/529, m.148), the defendant and the deceased "met on a sudden occasion, called chance medley" and fought, and so "the defendant feloniously slew the deceased not of malice aforethought but on a sudden occasion" ("ex casu subito vocato chauncemelle obviaverunt . . . ex nulla malitia precogitata sed ex casu subito felonice interfecit"). In R. v. Pulter, KB 27/1079, Rex m.4 (1531), the defendant, indicted for murder, alleged the act had been committed "on a sudden occasion" 
During the two ensuing decades, statutory pronouncements with respect to homicide continued this dual classification, though the terminology changed somewhat. Felonious slayings were either "murders" or "manslaughters."249 For example, the Bill for the Household, enacted in 1541, proclaimed:

Where treasons, misprisions of treasons, murders, manslaughters and other malicious strikings, by reason whereof blood is or shall be shed, against the King's peace ... . within the limits of the King's palace ... [t]hat all [the said acts] shall be . . . enquired of, tried, heard and determined . . . .

....

... And if any such person, or persons, so indicted and arraigned, be found guilty of any [of the said acts] that then all and every such person and persons so found guilty, shall have judgment of life and member, and suffer such pains of death . . . .250

Manslaughters were not excusable homicides; they were "malicious strikings." Nor were they murders, though, under this enactment, manslaughters in the royal household were to be treated in the same manner as murders.

"Manslaughterers" referred to slayers less culpable than murderers and thus eligible for the administrative shelters from punishment: benefit of clergy, sanctuary, and royal pardon. Manslaughterers were nevertheless sentenced to hang, and the sentence was executed, when, for example, due to illiteracy, administrative protection was unobtainable. Manslaughter had not yet become a lesser gradation of homicide, automatically meriting a lesser punishment. ${ }^{251}$

("subito casu") and not "ex malitia precogitata." He pleaded the general (statutory) pardon of 1530 , which would not have been necessary if his allegation amounted to an assertion of excusable homicide. Finally, in R. v. Hudson, KB 27/1114, Rex m.4 (1540), a statutory pardon was allowed for "chaunsmelle", because "it is not prepensed or voluntary murder" ("non est pretensum neque voluntarium murdrum"). (I am extremely grateful to Dr. John Baker, Fellow of St. Catherine's College, Cambridge University, for these references. They are drawn from a typescript draft of Dr. Baker's introduction to his edition of the Reports of Sir John Spelman, to be published by the Selden Society in 1977.)

249. For statutes using "murder" and "manslaughter" as terms of art, see, e.g., 27 Hen. 8, c. 4, § 1 (1535) (murder); 28 Hen. 8, c. 1, 11 (1536) (murder, manslaughter); 28 Hen. 8, c. 15, § 1 (1536) (murder); 33 Hen. 8, c. 12, 11 (1541) (murder, manslaughter). 1 Edw. 6, c. 12 (1547) (murder). This last, important statute did not use the term manslaughter since it dealt solely with acts for which clergy might not be granted: i.e., "wilful murder of malice prepensed."

250. 33 Hen. 8 , c. $12, \S \S 1,6$.

251. It is important to recognize, I believe, that culpability did not turn on "malice prepense"; the distinction between murder and manslaughter was determinative only of the availability of benefit of clergy. Moreover, the clergy statutes were inconsistent. From 1536 to 1547 , it would appear, neither murder nor manslaughter was clergiable. A 1547 statute again excluded murder from the benefit, 1 Edw. 6, c. $12, \S 9$, and so revived the importance of "malice prepense." The reading test for clergiability soon became a near fiction; it was abolished in 1706. 5 Anne, c. 
Salisbury's Case, ${ }^{252}$ the earliest reported verdict of manslaughter, reveals both the judicial application of the statutory murder-manslaughter distinction and the fact that the distinction was superfluous in cases where the defendant, for whatever reason, was unable to plead clergy. In 1553, John Vane Salisbury was tried with his master and two others on an indictment for murder. Salisbury had joined in a fray already under way and the question arose as to whether he was privy to a conspiracy to commit homicide. The court ruled that if the jury found Salisbury "did not have malice aforethought ["malice prepense"], but suddenly ["sodeynement"] took part with those who had malice aforethought, this would be manslaughter in him and not murder, because he did not have malice aforethought."253 The jury convicted the three others of murder, but found that Salisbury had "killed the man, but not of malice aforethought, and thus they acquitted him of murder, and found him guilty of manslaughter."254

The entire court was of the opinion that they might still pass judgment of death on Salisbury for manslaughter:

And because the malice aforethought made the act more odious, and because of this the defendant lost divers advantages, which he otherwise had, such as sanctuary and clergy, and the like, still it is not other than the manner of the deed, and not the substance of the deed, for the substance of the deed is the killing of the man . . . and if the jurors found the substance, and not the manner, still judgment will be given for the substance. ${ }^{255}$

But, in the end, Salisbury was reprieved because of the court's doubt as to the effect of a variance between the verdict and the indictment. $^{256}$ I believe we may fairly infer that, had Salisbury been literate, the point would have been moot. At the worst, the verdict of manslaughter would have forced him to plead his clergy and be branded before going free.

$6, \S 6$ (in Statutes of the Realm, 6 Anne, c. 9, $\$ 4$ ). Thereafter, manslaughter was, in effect, automatically punishable only by imprisonment, branding, or some other means short of death. Benefit of clergy itself was abolished in 1827. $7 \& 8$ Geo. 4, c. 28.

252. E. Plowden, Ies Commentarues f.100 (1578).

253. Id. at f.100b.

254. Id. at f.101.

255. Id.

256. Id. Later cases resolved this issue against the defendant. See M. HALE, supra. note 245, at 438 ("Upon an indictment of murder, though the party upon his trial be acquitted of murder, and convicted of manslaughter, he shall receive judgment, as if the indictment had been of manslaughter, for the offense in substance is the same"). Brooke seems to suggest that this very point had been raised in a case during the reign of Henry VII, some years before Salisbury's Case, and had also resulted in conviction of the defendant. R. BRooke, supra note 104, Corone, pl. 222. 
The distinction between murder and manslaughter drawn in Salisbury's Case, which for centuries thereafter formed the heart of the law of felonious homicide, ${ }^{257}$ sheds important light on the distinction between murder and manslaughter at the midpoint of the sixteenth century. The decision helps us to understand the gist, if not the precise meaning, of the Tudor legislation dealing with benefit of clergy. It also suggests that by 1550 the formal rules of the law of felonious homicide were being reconciled with the persistent popular feeling about the scope of liability for homicide. ${ }^{258}$

257. See Kaye, supra note 5, at 589-601.

258. Kaye believes that the court in Salisbury's Case formulated this distinction between murder and manslaughter for the first time. He believes that neither the statute of 1390 , see note 181 supra and accompanying text, nor earlier Tudor legislation mandated different treatment for different forms of felonious homicide. Kaye does recognize some exceptions to this general rule. While most judges, he says, took the traditional common law view of culpable homicide, namely, that any deliberate killing, or any killing resulting from an unlawful act of violence to the party slain, was in the same category as killing which had been premeditated ... some lawyers, whether out of an attempt to interpret the somewhat shadowy distinctions drawn in the justices' manuals, or ... out of a growing desire to interpret as strictly as possible, even to the extent of misconstruing, the statutes withdrawing benefit of clergy, had come to think that a literal interpretation must be put on malice prepense....

Kaye, supra note 5, at 587.

Kaye argues that before Salisbury's Case chance medley, or manslaughter, referred only to a small group of "accidental" homicides resulting from an attempt to slay another person; all other felonious homicides were murders. Kaye relies heavily on Herbert's Case, British Library, Harleian ms. 5141, ff. 40-41 (1558), which was decided after Salisbury's Case, but before the latter was generally known. In Herbert's Case, the judges discussed the liability of one who had slain accidentally in the course of a premeditated attack on a third party.

In Kaye's discussion of Herbert's Case, Kaye, supra, at 577-82, he notes that the court discussed several cases of murder; he concludes that the discussed cases covered virtually all felonious homicides. However all of the cases involved at least a deliberate, premeditated, wrongful act. None involved a sudden fight between two parties neither of whom had set out to harm the other. Surely such acts must have been common, yet none of the members of the bench made reference to them in the course of the discussion of murder.

For his definition of chance medley as accidental homicide resulting from an attempt to slay another person, Kaye relies in particular on language of two of the judges in Herbert's Case, Brooke and Staundford. Brooke thought the slaying in Herbert's Case was not murder: "[I]t is only homicide, because it comes by chance medley .... ." Id. at 582 (translated from the original Law French). This is not a "definition" of chance medley: It is merely an assertion that the slaying in Herbert's Case was an instance of it. Staundford's views are also less than conclusive. At one point he cited as chance medley a truly accidental homicide resulting from a sudden encounter where the slayer had not engaged in an unlawful act. Id. at 583. At least in this context, "chance medley" was broader than the definition Kaye set forth: either it referred to accidental homicide in general or it referred both to accidental homicide in general and to homicide stemming from a sudden encounter. Staundford appears to have meant the latter, for at another point he stated that "murder" was employed to designate the heinousness of the crime "to show the difference between homicide by chance medley and homicide perpetrated through intent to murder." Id. (translated from the original Law French). Now, if for Staundford "chance medley" meant accident and nothing more, this passage would make little sense: where, in his view, did self-defense fit in? His distinction between "homicide by chance medley" and "homicide perpetrated with intent to murder" is consistent with 
As we have seen, several early sixteenth-century legal writers identified murder with ambush. ${ }^{259}$ Yet, under the court's instructions, had Salisbury come to the scene knowing his master's intent and with the thought of aiding him, it would not have mattered that Salisbury had not lain in wait. Salisbury would have been found guilty of murder. To what extent was this a novel view of the difference between murder and manslaughter?

It is not surprising that the early sixteenth-century writers identified murder with ambush. Ambush, taking the victim off guard, made the act particularly serious. As early as 1390, however, the concept of especially serious homicide had come to include not only homicide through stealth, but also truly premeditated attacks that in general put the victim at a significant disadvantage. While "murder" in the 1390 statute was closely identified with the ancient morth, killing through stealth, it was also modified by assaut (assault) and malice prepense (malice aforethought). ${ }^{260}$ The "murderer" of the statute acted aggressively and deliberately, his intention already formed. His act was not merely a response to provocation at the moment of attack.

Despite this early development of the concept of murder, "lying in wait" remained an effective shorthand means of reference for especially serious homicide. It in fact signaled preformed intent, true malice. The Boke of Justyces of the Peas, as we have seen, ${ }^{201}$ defines "murder" as "where a man by malice prepensed lies in wait" and where the person slain could make no defense. But the Boke states also that a murderer slays "according to that malicious intent and purpose," while manslaughter is where two or more meet and "by chance medley they fall at affray so that one of them slays the other." In murder, according to the Boke, there is surprise but also a premeditated "intent and purpose"; in manslaughter, on the other hand, not only is there no surprise but the falling out is sudden: The slayer had no malicious intent at the time of the meeting. The element of surprise does seem especially important in the Boke; this perhaps reflects the author's dependence upon the technical definition of "murder" in the fourteenth-century precedents. But the author also noted the distinction between sudden falling out and prior malicious

the distinction, reflected in contemporary cases, between felonious homicide on a sudden occasion and through murder. See note 248 supra. The slaying in Herbert's Case was admittedly of another sort; perhaps because it involved some degree of accident, Staundford assimilated it to chance medley.

259. See text at notes $227,230,234$ supra.

260. See 13 Rich. 2, stat. 2, c. 1, quoted in note 179 supra.

261. See text at note 230 supra. 
intent, and it is this latter distinction that the sixteenth-century bench adopted.

This distinction, the basis of the modern law of murder and manslaughter, brought the formal rules more closely into line with community values. By defining malice prepense as actual premeditation, the courts excluded from murder the large class of slayings that stemmed from sudden fights. ${ }^{262}$ These simple homicides were a fact of daily life that the law was powerless to prevent. So long as people drank together, argued, and fought with each other, there would be blows that did unintended damage and wounds that became infected. Retreat from attacks might be socially scorned. Men would join brawls to help their relatives, friends, or masters; to stay out of the fray might reveal a lack of loyalty. Whatever doubts may be entertained in a later age about the wisdom of the sixteenthcentury distinction based upon "malice aforethought," tion reflected powerful social mores.

An examination of the elaborations of the concept of malice aforethought and the establishment of exceptions to the rule that murder depended upon true premeditation lies beyond the scope of this essay. ${ }^{264} \mathrm{I}$ have been concerned with tracing the distinction between murder and manslaughter as it first emerged in the reported cases. In devising that distinction, the courts were acting pursuant to statutory formulations nearly half-a-century old. But these developments did not transpire in a vacuum. Consideration of the reasons for the development and its success in taking hold in the law brings us back to the problem of the jury and the nature of trial procedure in the operation of the criminal law.

\section{B. Instruments of Change in the Law of Homicide ${ }^{265}$}

The statutes defining eligibility for benefit of clergy, unlike the

262. See R. Crompton, L'Office et Authoritee de Justices de Peace f.23b (1587) ("Manslaughter is where two fight together on the sudden, without malice aforethought, and one kills the other, there he will have clergy"); W. LAMBARDE, ErRENARCHA 24b (1607) ("[T]he former is fitly named chance medley for that in it men are meddled by mere chance, and upon some unlooked for occasion, without any former malice or evil mind in one to offer hurt to the person of the other").

263. See Kaye, supra note 5 , at 365,601 .

264. For an excellent discussion of the judicial elaboration of murder and manslaughter in the late sixteenth and seventeenth centuries, see id. at 587-601. Although Kaye believes Coke's discussion of felonious homicide in the seventeenth century reflected recent and novel judicial interpretation, see id. at $365, \mathrm{I}$ believe it is entirely consistent with the approach of the early sixteenth-century writers and statutes and their fourteenth-century precursors. See generally E. CoKE, supra note 245, at 47-57.

265. The argument presented in this section is highly tentative. It depends on 
statute of 1390 , succeeded in making a lasting impact on the substantive law of felonious homicide. Perhaps the most important difference between these two attempts to deal with professional or otherwise serious homicide was the stage of the judicial process at which the protection proscribed by the legislation was normally obtained. As we have seen, pardons of grace were obtained before trial, and, until 1390, they foreclosed prosecution. Thereafter, while courts were empowered, perhaps required, to test such pardons, they generally took at face value almost all pardons set before them and thus, by default, left administration of the statute of 1390 to the Crown. ${ }^{200}$

Benefit of clergy operated in a different way. Although in the Middle Ages it initially could be pleaded either at the outset of the trial or after an adverse verdict, ${ }^{267}$ a trial was always held, a jury impaneled, and a verdict given. Under the original doctrine of benefit of clergy, the court turned convicted clerks over to the Church for punishment according to canon law. ${ }^{268}$ The jury verdict was obtained, in the words of the rolls, in order that the royal court might know in what condition to deliver the defendant. ${ }^{260}$ As access to the benefit broadened, the defendant was no longer turned over to the Church. By the sixteenth century, if not before, clergy was pleaded after conviction and before sentencing. The sentence for most successful pleaders of the benefit was branding and, at the discretion of the court, up to a year's imprisonment. ${ }^{270}$

Because many convicted defendants were now likely to attempt to plead clergy, ${ }^{271}$ and because clergy was not available for all offenses, the nature of the felonious homicide became an important jury question. For the first time, it would seem, juries had to be questioned systematically as to the specific nature of the defendant's felonious

several generally accepted but as yet largely untested assumptions about sixteenthcentury trial procedure. Important work on extant Elizabethan records is now being done, see note 303 infra; perhaps that work will shed further light on the arguments presented here.

266. See note 195 supra.

267. In the reign of Henry VI, it was established that the "clerk" had to be convicted before claiming the benefit. $1 \mathrm{~J}$. STEPHeN, supra note 53, at 460 . See $\mathrm{L}$. GABEL, supra note 217 , at 30 .

268. See L. GabeL, supra note 217, at 30-31; S. MILsom, supra note 29, at 368.

269. See, e.g., JUST 3/127D, m.11d (1337).

270. 18 Eliz., c. 7, \& 2 (1576).

271. Approximately one quarter of all trial defendants succeeded in pleading benefit of clergy. See J. CockBurN, A History OF ENGLish Assizes 129 (1972) (20 per cent of all felony defendants for the period 1558 to 1714); J. SAMAHA, supra note 220 , at 62 (28 per cent of all felony defendants in Essex for the period 1558 to 1602). I found comparable figures for homicide defendants in Elizabethan Sussex (28 per cent) and Essex (23 per cent). See text at note 288 infra. 
act. ${ }^{272}$ For the first time, a jury verdict of "felony but not murder" might save the defendant's life, even though it would not spare him entirely from punishment. This statutory scheme presented an opportunity for legal growth.

It appears likely that changes in the trial procedure itself also played an essential role, both in the creation of new, more open tensions between bench and jury and in the elaboration of the law of homicide. The jury ceased during the later Middle Ages to be a selfinforming institution. ${ }^{273}$ While the process by which this occurred and the corollary emergence of the prosecution are largely hidden from our view, the later stages of prosecutorial development in the middle decades of the sixteenth century are more clear. ${ }^{274}$ The details of which we are aware suggest how the procedural changes resulted in changes in the law.

By the time of Salisbury's Case, the criminal jury trial differed markedly and significantly from its late fourteenth-century progenitor. ${ }^{275}$ The Marian bail and committal statutes of 1554 and 15541555 required justices of the peace to formulate depositions based on pretrial witness testimony, and these depositions were available to the court. ${ }^{276}$ They allowed the bench to play an active role in questioning witnesses and the defendant. Responsibility for management of the trial was divided between prosecution and bench; the prosecutor produced witnesses and their prepared depositions, ${ }^{277}$ while the judge

272. Salisbury's Case is the earliest recorded case that demonstrates this point. See text at notes 252-56 supra. There are no gaol delivery or criminal assize rolls for most of the fifteenth century or for the first half of the sixteenth century. My conclusion is a conjecture based on the requirements of the procedures involved.

273. See, e.g., J. Langbein, Prosecuting Crime in the Renaissance 118-22 (1974); T. Plucknett, supra note 19, 129-30; J. Thayer, A Preliminary Treatise ON EVIDENCE AT COMMON LAW 122-36 (1898).

274. See J. LANGBEIN, supra note 273 , pt. I.

275. For a discussion of criminal trial proceedings in the period 1558 to 1714 , see J. CockBurN, supra note 271, at 86-133. Cockburn presents a detailed picture of criminal proceedings, including evidence of bribery, jury-packing, and courtroom brawls. The simpler model presented here focuses on the relationship between the general characteristics of procedure and the law of homicide.

276. 1 \& 2 Phil. \& Mary, c. 13; 2 \& 3 Phil. \& Mary, c. 10. See J. LangBern, supra note 273, at 30 . There are very few extant depositions for the period 1550 to 1650 . See J. CockBuRN, supra note 271, at 334; J. LANGBEIN, supra, at 31 nn. 21-22.

277. The assize records from the latter half of the sixteenth century provide evidence regarding the production of witnesses at trial. See CALENDAR OF Assize RECORDS: SUSSEX INDICTMENTS, ELIZABETH I, at 263 no. 1388 (1593), 266 nos. 1400 (1593) \& 1401 (1593) (J.S. Cockburn ed. 1975) [hereinafter SUSSEX AssizE]. Most of the notations take the following form: "On 20 Oct. 1592 before Thomas Bishop, J.P., Richard Collvell of Newhaven, sailor, entered a recognizance to give 
put questions to all parties and controlled the structure of, and time allocation for, courtroom debate. ${ }^{278}$

In theory, the jury was still the final arbiter, and it retained power to consider not only the evidence presented in court, but also what it knew or had heard on its own. ${ }^{279}$ The origins of the modern law of evidence, moreover, lay in the future, and there was little, if anything, that the jury could not hear. ${ }^{280}$ Indeed, the mid-sixteenth-century trial has been described as an "altercation" 281 between the witnesses for the prosecution and the defendant, who spoke in his own behalf although neither under oath nor aided by counsel. But, while in theory juries might still take into account what they already knew, in practice they in most cases simply weighed the evidence presented at trial. The judge heard this evidence at the same time as the jury and framed his charge largely in terms of it. ${ }^{282}$ As in the past, the jury retired to reach a conclusion, but now nearly all the facts that they were to consider were known also to the bench.

The development of the prosecution must have significantly redressed the courtroom balance of power between judge and jury. Having lost its total control over the production of evidence, the now largely passive trial jury could no longer conceal the disparity between its verdict and the available incriminating evidence in cases where it wished to nullify the effects of the official rules. This alone may have affected jury behavior in many cases where the evidence produced in

evidence against [the defendant]." Id. at 266 no. 1401 (1593). The deceased in this case was injured on July 27 and died on August 10; the coroner's inquest was held August 11 with trial at the assize held February 26. In none of the cases do the records indicate whether the witness in fact appeared at the trial. See generally J. CockBuRs, supra note 271, at 103. Although the Sussex calendar does not systematically include the names of persons who were bound over to appear as witnesses until the 1580's, there are enough examples from earlier years to suggest that the binding over of witnesses was common throughout the period 1559 to 1603 . See, e.g., SusseX AsSize, supra, at 3 no. 11 (1559), 3-4 no. 14 (1559) (indictments for grand larceny).

278. See T. Smith, De Republica ANglorum 79-81 (1583). 1670).

279. See, e.g., Bushell's Case, 124 Eng. Rep. 1006, Vaughan's Rep. 135 (C.P.

280. See T. SMrT, supra note 278 , at $79-80$.

281. Id. at 80 .

282. In Salisbury's Case, for example, the judge charged the jury as follows: You the members of the jury have heard the evidence which has been given in order to prove the prisoners guilty of murder .....

And sirs [members of the jury] we understand the law to be that, the death of him [i.e., the servant who was slain] was murder on the part of the prisoners, if they killed him as a result of the malice they had toward his master; thus, if you find that they had malice toward the Doctor, this malice made the death of the one who was slain, who was his servant and in his company, to be murder by judgment of the law.

E. PlOWDEN, supra note 252, at f.101. 
court against the defendant was substantial. Perhaps more important, these developments placed the judge in a far better position to monitor verdicts, to separate those that were consistent with the evidence from those that were not. It might not be coincidental, therefore, that, by the middle of the sixteenth century, judges sometimes openly threatened jurors with fines or imprisonment and, in at least some cases, brought recalcitrant jurors before the Court of Star Chamber. ${ }^{283}$

This shift from a trial dominated by the self-informing jury to a trial based mainly on evidence produced by the prosecution not only revolutionized the relationship between judge and jury, but also gave greater importance to the judicial charge and made feasible the growth of the substantive criminal law. The open confrontation between the witnesses and the defendant must have produced far more candid testimony than the conclusory tales that juries had formerly recorded in their verdicts. Now close and difficult cases came inescapably to the attention of the bench. ${ }^{284}$ Complicated testimony of a sort not heard before forced the judges to refine and elaborate the original rough distinction between murder and manslaughter, and in this process the modern law of homicide emerged.

The combined effects of the benefit of clergy statutes and of the transformation of the criminal trial itself were several and profound. Some of them are easily traceable in the reports and legal literature of the late sixteenth and early seventeenth centuries; others are still a matter of speculation. One clear result of these changes was that the

283. According to Cockburn: "By the 1570's the right to threaten juries, either before or after their verdict, in order to secure a decision in accordance with the wishes of the bench was an accepted convention." J. CockBURN, supra note 271, at 123. It is unclear how frequently judges made good their threats. For a famous example of the imposition of a fine and imprisonment by the Court of Star Chamber, see Trial of Nicholas Throckmorton, 1 Complete Collection of State Trials 902 (Guildhall 1554) (T. Howell ed. 1816). See 5 W. HoldsworTH, History of ENGLISH LAW 203 (2d ed. 1937); T. PluCKNETT, supra note 19, at 131-34.

There are assize-calendar notations that jurors were held over "to appear at the next assizes or, in the meantime, in Star Chamber, if required, for acquitting ... against the evidence." E.g., SusSEX ASSIZE, supra note 277, at 51 no. 240 (1568). Such notations, however, are rare in homicide cases. Cockburn's conclusion that "[a] display of judicial displeasure was usually sufficient to ensure the reversal of unacceptable verdicts ...." J. CockBURN, supra, at 123, must remain tentative. There is no clear evidence that the sixteenth-century bench frequently succeeded in coercing guilty verdicts from juries that preferred to acquit, certainly not in homicide cases where conviction would lead to execution. Two of the best-known seventeenthcentury incidents of successful judicial badgering of juries, however, did occur in homicide cases. See note 304 infra.

284. Kaye's discussion is based on such cases. See Kaye, supra note 5, at 578601. Compare Herbert's Case, British Library, Harleian ms. 5141, ff.40-41 (1558), discussed in Kaye, supra, at 577-82. 
law of homicide evolved within a matter of decades into one of the most complex areas of the substantive criminal law. For the purpose of determining eligibility for clergy, the general rule of Salisbury's Case, which distinguished deliberate but sudden homicide from homicide through true premeditation, was further refined. ${ }^{285}$ Inevitably, exceptions had to be devised to govern the myriad situations for which the general rule was awkward or unwise. For example, of all the new doctrinal strands, none was more difficult to apply than the rule of manslaughter committed in "hot blood."286 Rules applicable to the slaying of officials-most importantly, the rule of implied malice, which made such slayings murder-also took a heavy toll of the once-streamlined law of intentional slaying. ${ }^{287}$

A second, less easily traceable result of the benefit of clergy statutes and the changes in trial procedure was their effect upon jury behavior. Since assize records are primarily indictments with brief and sometimes ambiguous notations as to the outcome at the trial stage, they do not provide very keen insight into jury behavior. Nevertheless, the pattern of late sixteenth-century jury verdicts is revealing.

285. The rule that made unpremeditated homicide mere manslaughter was eventually modified in three areas: A sudden attack that caught the victim off guard might still be murder; a sudden unpremeditated attack on an officer of justice was held to be murder; and an unpremeditated killing resulting from another intentional unlawful act amounted to murder. See Kaye, supra note 5, at 590-92.

286. Slaying in "heated blood" or "continuing fury" led to a verdict of manslaughter, but slaying after the fury had abated, or was thought to have abated, was murder. See 8 W. HoldSWORTH, supra note 283, at 303; Kaye, supra note 5, at 589 . 90. The difficulties involved in the application of the rule may be seen in a case from an unpublished law report, Harvard Law School ms. 112, at 296, reprinted in Baker, Criminal Justice at Newgate 1616-1627, 8 IR. JUR. 307, 315-16 (1973):

Two men were fallen out upon malice aforethought upon a particular and special matter between them. They were reconciled and continued in love and friendship together 2 or 3 years. And afterward, upon a sudden conference about the old business, they fell at variance again and the one killed the other. Whether this were murder or manslaughter was the question. But clearly if the quarrel had been about some new matter it had been but manslaughter. But it was ruled in the King's Bench that where there was an ancient quarrel between two concerning a matter and afterward they two meet suddenly and contend about another new occasion without mention of the former, and thereupon heat grows and the one kills the other, this is murder, because the old quarrel continued without reconciliation.

287. Kaye suggests, "Here, it was simply the needs of public policy which prevailed over the 'sudden encounter' doctrine: attacks upon officers seldom were premeditated, for of their nature they arose only when a given officer attempted to carry out his duties." Kaye, supra note 5, at 591. A doctrine of "malice implied by law" developed "and, once this was done, it was a short step to 'implying malice' in cases where an officer was engaged in the performance of duties unconnected with keeping the peace, e.g., arresting for debt." Id. at 592. 
TABle: Verdicts Rendered at ElizabethaN

ASSIZES $(1558-1603)^{288}$

\begin{tabular}{|c|c|c|}
\hline Verdicts & Sussex & Essex \\
\hline \multicolumn{3}{|l|}{ Guilty } \\
\hline To be hanged & $24 \%$ & $13 \%$ \\
\hline Allowed clergy & $28 \%$ & $23 \%$ \\
\hline $\begin{array}{l}\text { Sentence unclear } \\
\text { (perhaps hanged, } \\
\text { perhaps clergy) }\end{array}$ & $\begin{array}{r}5 \% \\
57 \%\end{array}$ & $14 \%$ \\
\hline \multicolumn{3}{|l|}{ Excusable homicide } \\
\hline $\begin{array}{l}\text { Self-defense } \\
\text { Accident } \\
\text { Insanity }\end{array}$ & $\begin{array}{l}3 \% * \\
2 \% * * \\
1 \% \\
6 \%\end{array}$ & $\begin{array}{r}8 \% \\
3 \% \\
0 \% \\
11 \%\end{array}$ \\
\hline $\begin{array}{l}\text { Total excusable } \\
\text { Not guilty }\end{array}$ & $\begin{array}{r}6 \% \\
37 \%\end{array}$ & $39 \%$ \\
\hline \multicolumn{3}{|c|}{$\begin{array}{l}\text { * } 6 \text { other persons (approximately } 6 \% \text { ) were apparently not } \\
\text { tried because the coroner's inquest had found they had slain } \\
\text { in self-defense. } \\
\text { ** } 2 \text { other persons (approximately } 2 \% \text { ) were apparently not } \\
\text { tried because the coroner's inquest had found they had slain } \\
\text { by accident. }\end{array}$} \\
\hline
\end{tabular}

The evidence available shows that, while as compared with the fourteenth century ${ }^{289}$ the conviction rate was high (fifty per cent or more as compared with twenty to twenty-five per cent), the percentage of defendants actually condemned remained about the same (twenty to twenty-five per cent) ${ }^{290}$ and the percentage of self-defense verdicts

288. This table shows the breakdown of verdicts in homicide cases, excluding cases of infanticide and homicide through witchcraft, tried at the Elizabethan assizes, 1558-1603, in Sussex and Essex counties. Both these counties were part of the Home Circuit, one of six judicial circuits and the only circuit for which Elizabethan criminal records exist. The Home Circuit "included two predominantly rural countiesSussex and Hertfordshire-and three populous shires-Essex, Kent, and Surrey. . . . J. CockBuRN, supra note 271, at 99. This study, then, represents a reasonable sample of the extant evidence. The Sussex Assize Calendar has recently been published, see note 277 supra; for Essex, the Essex Record Office typescript calendar [hereinafter Essex Record Office Assize Calendar] was used, and my figures are only' approximate. There were approximately 100 homicide defendants for whom trial verdicts were rendered in each county.

Cases of infanticide and homicide through witchcraft have been excluded in order to avoid distortion. Such cases rarely appear on the pre-1500 trial rolls. Most defendants in such cases were women, and the conviction rate was high. These cases, which deserve extensive study, do represent new departures either in social attitudes or in the use of the legal system to give effect to those attitudes.

289. See text at notes $62-65,68,72$ supra.

290. It is not at all certain that in the sixteenth century every defendant for whom a judgment of "guilty: to hang" was entered was in fact hanged. See J. Cock- 
was significantly lower (three to eight per cent as compared with ten to forty per cent). Thus, it appears that juries, recognizing that benefit of clergy provided an alternative sanction for simple homicide, felt free to convict in many cases that had formerly falsely been described as acts of self-defense. The formal rules and the social response had come closer together; more often than in the past, we may speculate, recipients of pardons for self-defense were in fact true self-defenders. ${ }^{291}$

Finally, judicial refinements of the law of excusable homicide may have been a third result of the benefit of clergy statutes and the transformation of the criminal trial. The extension of justifiable homicide by the statute of 1532 to cover slayers of would-be murder$\mathrm{ers}^{202}$ may have been facilitated by the diminished fear that manslaughterers would be acquitted along with true self-defenders. Indeed, while officially the medieval treatment of excusable homicide was not abolished until $1828,{ }^{293}$ there is evidence that judges frequently allowed self-defenders, whether they had slain murderers or not, to go quit without pardon or forfeiture as early as the sixteenth century. ${ }^{294}$ This too may have reflected heightened judicial confidence in jury verdicts.

BURN, supra note 271, at 129-33. Judges increasingly substituted other forms of pun. ishment, for example, transportation overseas, for execution, but this probably was not common before 1600 . Id. at 130 .

291. For cases at the Sussex assizes ending in verdicts of self-defense, see Sussex AssIZE, supra note 277, at 281-82 no. 1475 (1594), 319 no. 1639 (1596), 333 no. 1714 (1597). Unfortunately, because the indictments are very curt, no solid conclusions can be drawn from them. Moreover, there is no indication of the nature of the evidence actually produced at trial.

292. See text at notes $242-45$ supra.

293. See 9 Geo. 4, c. 31 , § 10.

294. Very little is now known (or may ever be known) about judicial treatment of defendants for whom a jury returned a verdict of self-defense. Scholars have assumed that even before the statute of 1828,9 Geo. 4, c. $31, \S 10$, judges allowed juries to acquit such defendants, but the evidence these scholars have adduced is inconclusive. See M. Foster, Discourse ON HoMicide 288-89 (2d ed. 1776); 2 F. Pollock \& F. Marrland, supra note 5, at 481 n.3; 3 J. STEPHEN, supra note 53, at 76-77. Beale asserts that, due to a liberal interpretation of the statute of 1532 (involving slayers of murderers and robbers), a judge allowed a defendant to go free on a verdict of self-defense as early as 1534. Beale, supra note 245, at 571. The Year Book report of the case is inconclusive. See Y.B. Trin. 26 Hen. 8, f.5, pl. 21 (1534).

The evidence from the assize rolls is also unclear on this point. In the late sixteenth century, there were still cases ending in verdicts of self-defense and, apparently, an order that the defendant obtain a pardon. See, e.g., Sussex Assize, supra note 277, at 319 no. 1639 (1596); Essex Record Office Assize Calendar, supra note 288 , at 354 nos. 41 and 42 (1594). In other self-defense cases there is no indication that a pardon was required. See, e.g., SuSSEX AsSIZE, supra, at 281-82 no. 1475 (1594), 333 no. 1714 (1597). Whether forfeiture was incurred in any of these cases is unclear. Other cases ending in notations of "not guilty" might be cases in which the jury in fact gave a special verdict and the bench then acquitted the defendant 
The history of judicial treatment of accidental homicide, on the other hand, appears to be more complex. It is difficult to unravel the line of development that extends in this area from the adoption, in the fourteenth century, of the rule of automatic forfeiture for excusable homicide to the abolition, in the nineteenth century, of both pardon and forfeiture. At the outset of the period, the judicial handling of accidental homicide was relatively lenient. As we have seen, the courts granted acquittals in a wide variety of cases that had formerly led to pardons for accidental homicide. ${ }^{295}$ The theory most often employed to rationalize acquittal in these cases was that the deceased, through his own actions, had slain himself. Although this theory was, at least once, repeated in the sixteenth century ${ }^{296}$ and might still have governed the outcome of some cases, it is clear from the notations of judgments on the late sixteenth-century Chancery records that pardon procedures were followed in the majority of accidental homicide cases. ${ }^{297}$

The reasons for this strict treatment of accidental homicide are not altogether clear. The most dramatic aspect of the new approach was the insistence upon initiating the pardon procedure for deaths resulting from shooting accidents, both by bow and arrow ${ }^{298}$ and by firearms. ${ }^{299}$ The latter devices, of recent invention and currency, were responsible for close to forty per cent of the accidental homicides for which pardons were granted in the century 1550 to $1650 .{ }^{300}$ The dangers surrounding the use of firearms might have contributed to judicial conservatism in accidental homicide generally, and this

and had the clerk indicate as much on the assize roll. But it is impossible to demonstrate that that is the case.

The strongest evidence for the proposition that self-defenders were not required to obtain pardons is the fact that the Chancery class 260 , which contains many post-1550 cases in which the pardon procedure was required for accidental homicide, contains practically none by that late date for homicide in self-defense.

295. See text at notes 115-51, supra.

296. See, e.g., W. STAUNDFord, supra note 145 , at $16 \mathrm{a}$, commenting on a 1370 case, Y.B. Hil. 44 Edw. 3, pl. 94. It is likely that this problem was the subject of some discussion in the lectures held in the Inns of Court before 1540 that Dr. John Baker is examining in the course of preparing his work on Spelman. See note 248 supra.

297. See Chancery classes 260 and 244 , passim. The hundreds of cases where pardon procedure was followed for accidental homicide between 1550 and 1650 suggest that judges were infrequently allowing such defendants to go quit. Notations in the Sussex Assize, supra note 277, and the Essex Record Office Assize Calendar, supra note 288 , are inconclusive.

298. See, e.g., C 260/166, no. 20 (1573); C 260/171, no. 46 (1583).

299. See, e.g., C 260/173, no. 52 (1588); C 260/184, no. 31 (1631).

300. This estimate is based upon a study, made for me by David Clark of the Public Record Office, of the post- 1550 cases contained in Chancery classes 260 and 244. 
concern might explain the insistence on pardons in cases of unintentional slayings through the use of more traditional weapons.

It is also possible that the flow of evidence now revealed more clearly than before the degree of negligence attributable to the defendant in accident cases. Juries, having lost most of their control over the production of evidence, might have found it more difficult to persuade the court that the deceased had been responsible for his own death. Indeed, jury verdicts of excusable accidental homicide might have been returned in cases that, according to the evidence produced at trial, appeared to the bench to fit within the emerging category of involuntary manslaughter. ${ }^{301}$ Surely, in these cases, the bench might have deemed insistence upon the pardon requirement entirely appropriate.

In those (presumably) rare instances, on the other hand, where trial testimony was consistent with a special verdict that the deceased had slain himself in the course of an attack upon the defendant, the bench might have felt greater confidence in assimilating the cases with self-defense and allowing an acquittal. ${ }^{302}$ If so, this was one more example of the effect of the new trial procedure on judicial treatment of excusable homicide. But this remains a matter of speculation. $^{303}$ Certainly, tension between judge and jury as to the

301. This category was recognized as early as 1576. See R. Brooke, supra note 104, Corone, pl. 229; Kaye, supra note 5, at 593 (discussing Brooke's view).

302. Such cases rarely appear among those accidental homicides for which pardons were granted.

303. The history of the jury and the law of homicide after 1550 remains shrouded in mystery. The subject requires a systematic analysis of the series of criminal assize records that begin in the 1550's. These records are being edited for publication by James Cockburn of the University of Maryland and the English Public Record Office. Volume 1, for the county of Sussex, has already appeared. See Sussex Assize, supra note 277.

I have suggested that the emergence of a large category of noncapital felonious homicide and the beginnings of modern trial procedure produced changes in the behavior of both bench and jury. My tentative thesis is that the conditions that had produced the earlier pattern of jury behavior and judicial response had been substantially removed. There were fewer verdicts of self-defense, see text at note 288 supra, and probably there was greater judicial leniency in those cases that did occur, see note 294 supra. Factors other than the existence of a category of noncapital felony and the new trial procedure probably played an important role. But these factors, I believe, must be considered in relation to the formal law and trial procedure. Juries might have been comprised of persons less inclined to save defendants through verdicts of excusable homicide, but it may still be true that, absent the category of man. slaughter, they would not have been willing to convict. Judges might have threatened and fined juries to force convictions, but it is hard to see how these measures could easily have been applied had trial procedures remained unchanged: As in earlior times, it would have been extremely difficult to separate the cases of honest verdicts from the cases of pure fabrication.

I have introduced these statistics on jury verdicts to establish a relationship between the structure of formal legal categories and jury behavior, and to suggest that, taken at their broadest, characteristics of social attitudes towards homicide remained 
border between manslaughter and excusable homicide was still common after the middle of the sixteenth century. ${ }^{304}$

\section{CONCLUSION}

The emergence of a distinction in Tudor times between murder and less serious felonious homicide was not a historical accident. Nor was it a conceptual breakthrough that we owe to the late Tudor

fairly constant throughout the period 1300 to 1600 . I do not mean to suggest that these observations constitute an in-depth picture of the social history of the law of homicide in Elizabethan England. Further research can shed light on a number of important questions and provide significant refinement of the rough outline presented here. It is possible to determine the social status of defendants and jurors in homicide cases and to correlate that information with verdicts. It may also be possible to establish differences in the practices of justices of the peace and the bench. See, e.g., Samaha's analysis of the extant Essex criminal records. J. SAMAHA, supra note 220.

304. The parliamentary censure of Lord Chief Justice Keeling in 1667 for his abusive tactics with respect to trial juries provides a particularly dramatic insight into judge/jury relations in felony cases. Keeling was charged before the House of Commons with threatening both grand and petty juries in several cases. One was described as follows:

[T]here happened a fray in which one man was slain; it was proved that the man that killed him was set upon and so did it in his own defence, and thereupon the jury found it se defendendo. The judge would not take this verdict, but caused them to go out again, but still they brought in the same verdict. He caused them to go out again, and threatened them to fine them if they brought in the same verdict; they being fearful brought it in manslaughter.

The Diary of John Milward, Ese. 160 (C. Robbins ed. 1938). In his defense, Keeling admitted the substance of the matter. John Milward, a contemporary diarist to whom we owe most of our knowledge of the proceedings, gives the following summary of Keeling's defense:

For that case when the jury brought in the bill or verdict se defendendo, it was this. Two men fell out, had their swords drawn and were parted, and after a while fell to fighting again. One of them was slain, but because it was said he that killed the other fled to the wall and afterward slew him therefore the jury would not find it murder, and for this he fined them.

Id. at 167.

A second case involved the conviction and execution of a weaver's servant for killing an apprentice weaver. According to Milward, Keeling dealt with it thus:

[A] weaver .... gave order to a servant and authority to oversee [apprentices] and in his absence to correct the younger prentices. . . . A prentice boy not

winding his pins ...., but neglecting his work, this servant beat him about the head with a broomstick, . . until blood gushed out of his nose, mouth and ears, of which the boy died. . . The jury would find this manslaughter; he caused them to go out again and bring it in murder, which accordingly they did, for which the man was condemned and hanged.

Id. at 168 . The charges leveled against the Chief Justice, and the parliamentary resolution that his behavior was "illegal" are calendared in 9 JOURNALs OF THE HousE of Commons 4, 35-37 (1667).

The Keeling incident took on heightened importance after 1670, when Chief Justice Vaughan ruled in Bushel's Case, 124 Eng. Rep. 1006, Vaughan's Rep. 135 (KB 1670 ), that juries could neither be threatened nor fined for returning a verdict at variance with the judge's views. Jury tracts after 1670 frequently supported their contentions with the argument that, in cases of homicide, the jury had an unbridled right to decide whether the slaying was murder, manslaughter, or a form of excusable homicide. See, e.g., H. CARE, ENGLISH'LIBERTIES 260 (1719 ed., originally published in 1680); J. Hawles, THE ENGLISHMaN's Right 11 (1680). 
bench. Rather, it represented the final stage of a long process by which the common law adapted to social views on capital felony. Those social views, as I have argued elsewhere, ${ }^{305}$ are ultimately traceable to the ancient Anglo-Saxon tradition making homicide through stealth unemendable and homicide committed in the open a matter for monetary composition. The imposition in the twelfth century of the death penalty for all felonious homicides produced a powerful tension between law and social attitudes. In time, the formal rules of the law might have prevailed, or the popular notions of culpability might have been completely adopted. Instead, the institution of the self-informing trial jury as a method of proof prevented either development. The jury came to play the pivotal role in the social history of the law of homicide. I have attempted in this article to explain legal developments against the background of the jury as an evidence-gathering body.

From its inception until the late Middle Ages, the trial jury controlled the flow of evidence, limiting the area in which the judges made decisions of law. So strict was the jury's control over judicial proceedings that for centuries the courts were limited to mechanical application of a few basic rules. In only a relatively small percentage of cases did the jury return a verdict of felonious homicide. In most cases, the jury either acquitted or produced a finding describing a classic case of self-defense. Even if the medieval bench had been inclined to question the wisdom of an unvarying rule of capital felony, the jury largely withdrew from it the occasion to do so.

The systematic description of simple homicides as cases of selfdefense further stultified legal development. Close cases were infrequently presented, precluding consideration on a case-by-case basis whether a particular act for which the existing law had no clear resolution constituted legitimate self-defense. Moreover, because the judiciary was aware of jury behavior, there was little incentive to loosen the strict rules of self-defense. Thus, the medieval law of intentional homicide retained a single clear division between excusable self-defense and all other homicides. There were no degrees of seriousness among felonious homicides; there were at first almost no degrees of excusability among intentional but pardonable homicides.

Development in the medieval law of homicide was stalled, but it was not completely precluded. In cases of justifiable homicide, the facts of defense of home or goods lay side by side with evidence of self-defense. Judges seized upon those facts indicating defense against the type of criminal activity that plagued society and held that

305. See Green, supra note 3, at 686-94. 
robbers and burglars might be slain without penalty. In this way, the legal categories came to operate more rationally with respect to some individual offenders.

The remaining group of "self-defenders" required pardon and suffered forfeiture. With respect to this group, the medieval law was less rational, for these slayers included both those who acted in selfdefense and truly merited pardons de cursu, and those who acted without legal excuse, but whom society deemed guilty of less than a capital offense. By the early decades of the sixteenth century, however, many of the latter were eligible for benefit of clergy and no longer required jury protection in order to escape hanging. The gradation of penalties through manipulation of benefit of clergy had freed the way for development of legal theory.

Nevertheless, mere gradation of punishment may not have been sufficient to cause a shift from social to judicial determination of what constituted murder as opposed to manslaughter. So long as the jury was self-informing, so long as it rendered a verdict that constituted the evidence officially before the court, the determination as to the level of offense remained in the jury's hands. What was required for substantive legal development was the transformation of the trial itself. When, in the course of the sixteenth century, evidence came systematically to be produced by the justice of the peace as prosecutor, or by witnesses bound over by him, the jury ceased in fact to be self-informing, and much of its control over legal categories was shifted to the bench. The jury might still have returned a verdict based on its own conception of the defendant or his deed, but the court construed the evidence produced at trial in its instructions to the jury, developed the law of homicide, and, where social and legal concepts continued to diverge, badgered the jury perhaps more effectively than before into conforming with the official rules of the law.

The age of nearly unlimited jury control was passing; the age of the law and of the bench was commencing. The conflict between judicial and social concepts of liability remained, to be played out perhaps less often but far more visibly in the courtroom relationship between judge and jury. Whether the jury would return a verdict clearly at odds with the evidence set forth by the prosecution, in the face of the judicial charge and threat of punishment, was now the question upon which control of the legal process depended. The "right" of the jury to do so had now to be invented and given a place in political and constitutional theory. 